Supporting Information

for

\title{
Studies of the Enantiocontrolled Synthesis of the C(10)-C(25) Subunit of Amphidinolide C
}

David R. Williams, ${ }^{*}$ (iD Ramkrishna De ${ }^{\dagger}$ Micheal W. Fultz, ${ }^{\ddagger}$ (iD Derek Fischer, ${ }^{\S}$ Ángel Morales-Ramos, ${ }^{\|\|}$ and David Rodríguez-Reyes ${ }^{t+}$

Department of Chemistry, Indiana University

Bloomington, IN 47405, United States

williamd@indiana.edu

\section{Page}

General Information

S-2 - S-3

Experimental Procedures and Characterization Data

S-3 - S-36

${ }^{1} \mathrm{H}$ and ${ }^{13} \mathrm{C}$ NMR Spectra (49 pages)

S-37- S-85 


\section{General Information}

Unless otherwise noted, all reactions were performed in flame-dried or oven-dried glassware under argon atmosphere. All non-volatile samples were pumped to constant weight at ambient temperature $(0.2 \mathrm{mmHg})$ following removal of solvents by rotary evaporation. Nonaqueous solutions were transferred using syringe techniques under argon atmosphere. Bulk grade hexanes and ethyl acetate for chromatography were distilled prior to use. Tetrahydrofuran (THF), dimethylformamide (DMF), toluene, acetonitrile $(\mathrm{AcCN})$, diethyl ether $\left(\mathrm{Et}_{2} \mathrm{O}\right)$ and dichloromethane $\left(\mathrm{CH}_{2} \mathrm{Cl}_{2}\right)$ were obtained anhydrous by degassing with argon and then passing through activated alumina columns to remove water. Triethylamine (Et $3 \mathrm{~N})$ and diisopropylethylamine (DIPEA) were distilled from $\mathrm{CaH}_{2}$ under dry argon immediately before use. Commercial reagents were used as obtained from vendors unless otherwise specified. Airsensitive reagents were handled inside a glovebox facility.

Reactions were monitored by standard thin-layer chromatography (TLC) techniques using silica gel 60 F254 on pre-coated glass plates $(0.25 \mathrm{~mm}$ thickness $)$. Following the run, TLC plates were visualized under UV light and/or by application of appropriate stains ( $\mathrm{p}$-anisaldehyde or cerium ammonium molybdate or potassium permanganate). Flash column chromatography was performed with Silica-P Flash Silica Gel (ultra-pure 40-63 $\mu \mathrm{m}$ ). Flash chromatography refers to the separation technique as described by W. C. Still, M. Kahn and A. Mitra, J. Org. Chem. 1978, 43, 2923-2925, "Rapid Chromatographic Technique for Preparative Separations with Moderate Resolution”. All flash chromatography separations are exclusively performed using silica gel as the support.

Proton nuclear magnetic resonance $\left({ }^{1} \mathrm{H}\right.$ NMR) spectra were recorded on 300, 400 and 500 $\mathrm{MHz}$ instruments. Carbon nuclear magnetic resonance $\left({ }^{13} \mathrm{C} \mathrm{NMR}\right)$ spectra were measured at 101 
$\mathrm{MHz}$, or $125 \mathrm{MHz}$. NMR coupling constants and signal patterns are reported as $J$ values in hertz $(\mathrm{Hz})$ and $\delta$ values in parts per million (ppm). ${ }^{1} \mathrm{H}$ and ${ }^{13} \mathrm{C}$ NMR spectra are internally referenced to residual solvent signals $\left(\mathrm{CDCl}_{3}\right.$ referenced to $\delta 7.26$ and $77.16 \mathrm{ppm}$ respectively). The following abbreviations were used to indicate the signal multiplicities: $s$, singlet; $d$, doublet; $t$, triplet; $q$, quartet; m, multiplet. High resolution mass measurements (HRMS) were obtained by EI or CI or ESI methods. Optical rotation data were obtained on a polarimeter and are reported in terms of degrees of rotation of the plane of polarized light using radiation at $589 \mathrm{~nm}$ wavelength (the sodium $\mathrm{D}$ line). The data is expressed as the specific rotation $\left(\alpha_{\mathrm{D}}\right)$ of the sample which may occur in the clockwise $(+)$ or counterclockwise $(-)$ direction where $\mathrm{c}$ is the concentration of sample in grams per $100 \mathrm{ml}$ of solution. IR spectra are reported in terms of frequency of absorption $\left(\mathrm{cm}^{-1}\right)$.

\section{Scheme 3 Content}

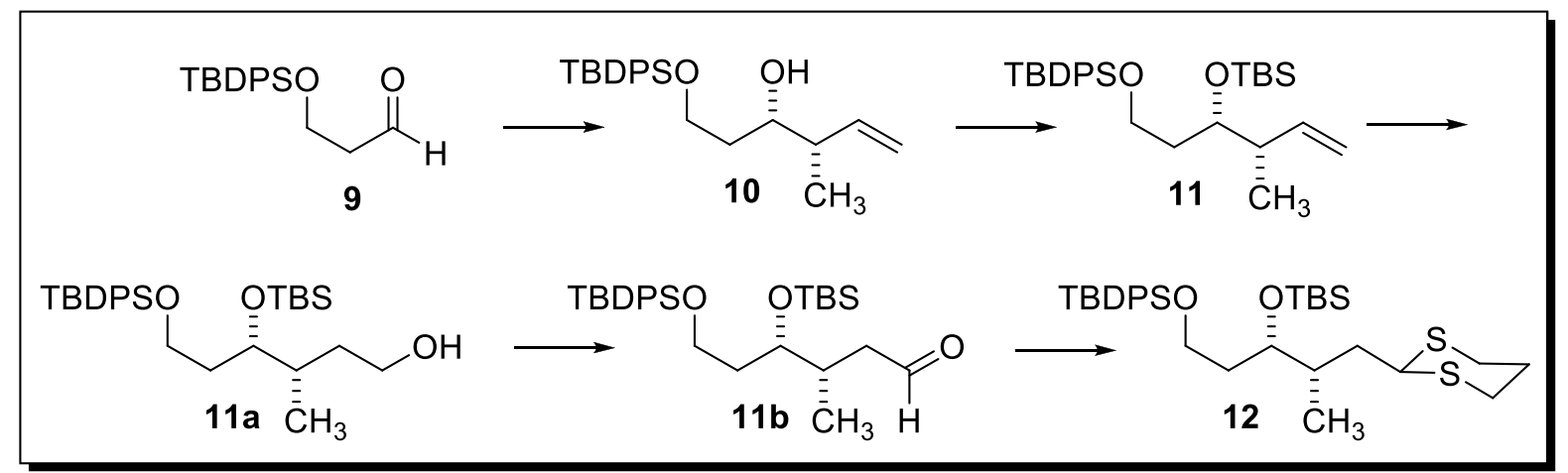




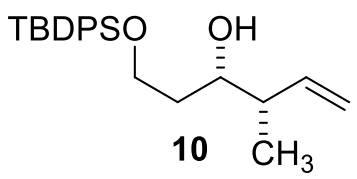

\section{Large Scale Preparation of Alcohol 10.}

The starting aldehyde 9 is a known compound. For a preparation of 9 , please see the published work of Habrant, et al. ${ }^{1}$ as one example of a variety of publication sources for this substance.

Potassium tert-butoxide (56 g, $459 \mathrm{mmol}$ ), was added to a 3-necked round bottom flask equipped with an addition funnel and mechanical stirrer. THF $(350 \mathrm{~mL})$ was added and the flask was cooled to $-40{ }^{\circ} \mathrm{C}$. Cis-butene $(42 \mathrm{~mL}, 450 \mathrm{mmol}$, previously condensed in a round bottom flask with dry ice condenser) was added via syringe. $n$-Butyllithium (2.5 M hexanes solution, 180 $\mathrm{mL}, 450 \mathrm{mmol}$ ) was added slowly and the reaction was allowed to stir 15 minutes. The orange solution was cooled to $-78^{\circ} \mathrm{C}$ and a solution of $(+)-B$-methoxydiisopinocampheylborane (149 $\mathrm{g}$, $471 \mathrm{mmol})$ in THF $(200 \mathrm{~mL})$ was added slowly via addition funnel. The clear solution was stirred 60 minutes at $-78^{\circ} \mathrm{C}$ prior to $\mathrm{BF}_{3}-$ etherate $(66 \mathrm{~mL}, 471 \mathrm{mmol})$ addition via syringe. Two minutes after complete $\mathrm{BF}_{3}$-etherate addition, aldehyde $9(83 \mathrm{~g}, 265 \mathrm{mmol})$ in THF $(100 \mathrm{~mL})$ was added slowly via addition funnel and stirred 4 hours at $-78^{\circ} \mathrm{C}$. The cooling bath was removed and a $3 \mathrm{M}$ $\mathrm{NaOH}$ solution $\left(900 \mathrm{~mL}, 2700 \mathrm{mmol}\right.$ ) was added followed by slow addition of $30 \%$ aqueous $\mathrm{H}_{2} \mathrm{O}_{2}$ $(150 \mathrm{~mL}, 1323 \mathrm{mmol})$ and stirred at room temperature for 18 hours. The reaction mixture was filtered through celite and washed with diethyl ether. The layers were separated and the aqueous layer was extracted twice with diethyl ether. The combined organics were dried over anhydrous magnesium sulfate, filtered, and concentrated at reduced pressure. The Isopinocampheol was removed by distillation at reduced pressure. The product was then purified by flash

1. Habrant, D.; Stewart, A. J. W.; Koskinen, A. M. P. Tetrahedron 2009, 65, 7927-7934. 
chromatography (silica gel, 27\% EtOAc in hexanes) to give $76 \mathrm{~g}$ of alkene $10(77 \%)$ as a clear liquid. Spectral properties were consistent with the reported data: ${ }^{2} \quad \mathrm{R}_{f}=0.5$ (20\% ethyl acetate/hexanes); $[\alpha]_{\mathrm{D}}^{25}-3.20\left(c=0.6, \mathrm{CHCl}_{3}\right) ;{ }^{1} \mathrm{H} \mathrm{NMR}\left(400 \mathrm{MHz}, \mathrm{CDCl}_{3}\right) \delta 7.74(\mathrm{~m}, 4 \mathrm{H}), 7.44$ (m, 6H), $5.83(\mathrm{ddd}, J=18.1,10.4,7.7 \mathrm{~Hz}, 1 \mathrm{H}), 5.08(\mathrm{~m}, 2 \mathrm{H}), 3.92(\mathrm{~m}, 2 \mathrm{H}), 3.79(\mathrm{~m}, 1 \mathrm{H}), 3.24(\mathrm{~d}$, $J=3.0 \mathrm{~Hz}, 1 \mathrm{H}), 2.32(\mathrm{~m}, 1 \mathrm{H}), 1.73(\mathrm{~m}, 2 \mathrm{H}), 1.11(\mathrm{~d}, J=6.6 \mathrm{~Hz}, 3 \mathrm{H}), 1.11(\mathrm{~s}, 9 \mathrm{H}) ;{ }^{13} \mathrm{C} \mathrm{NMR}(400$ $\left.\mathrm{MHz}, \mathrm{CDCl}_{3}\right) \delta 141.0,135.5,132.9,129.7,127.7,114.8,74.8,63.5,43.8,35.5,26.8,19.0,15.1$; IR (NaCl plate) 3440, 2955, 2895, 1645, $1471 \mathrm{~cm}^{-1}$; HRMS (ESI) $m / z:[\mathrm{M}+\mathrm{Na}]^{+}$Calcd for $\mathrm{C}_{23} \mathrm{H}_{32} \mathrm{O}_{2} \mathrm{Si} 391.2069$; Found 391.2059.

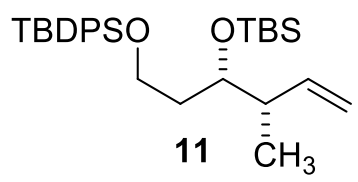

Alcohol 10 (58 g, $157.6 \mathrm{mmol})$ was dissolved in dimethylformamide (500 $\mathrm{mL})$ followed by the addition of tert-butyldimethylchlorosilane (33 g, $220 \mathrm{mmol})$ and imidazole (15 g, 220 mmol). The reaction mixture was stirred at room temperature for $15 \mathrm{~h}$. Water was added to quench the reaction and the layers were separated. The aqueous layer was extracted twice with hexane. The combined organic extracts were washed with brine, dried over magnesium sulfate, filtered and the solvent was removed at reduced pressure. The product was purified by flash chromatography (silica gel, 1\% EtOAc in hexanes) to give $71 \mathrm{~g}$ of alkene $11(94 \%): \mathrm{R}_{f}=0.25(5 \%$ ethyl acetate in hexane); $[\alpha]_{\mathrm{D}}^{25}-6.3\left(c 0.67, \mathrm{CHCl}_{3}\right) ;{ }^{1} \mathrm{H} \mathrm{NMR}\left(400 \mathrm{MHz}, \mathrm{CDCl}_{3}\right) \delta 7.67-7.64(\mathrm{~m}, 4 \mathrm{H}), 7.42-7.34$ (m, 6H), 5.91-5.82 (m, 1H), 5.00-4.94 (m, 2H), 3.81-3.77 (m, 1H), 3.73-3.67 (m, 3H), 2.32-2.28 $(\mathrm{m}, 1 \mathrm{H}), 1.69-1.54(\mathrm{~m}, 2 \mathrm{H}), 1.28-1.24(\mathrm{~m}, 2 \mathrm{H}), 1.04(\mathrm{~s}, 9 \mathrm{H}), 0.94(\mathrm{~d}, J=6.8 \mathrm{~Hz}, 3 \mathrm{H}), 0.85(\mathrm{~s}$, 9H), $0.03(\mathrm{~s}, 3 \mathrm{H}),-0.01(\mathrm{~s}, 3 \mathrm{H}) ;{ }^{13} \mathrm{C} \mathrm{NMR}\left(100 \mathrm{MHz}, \mathrm{CDCl}_{3}\right) \delta 141.1,135.6,134.0129 .5,127.6$,

2. Rauniyar, V.; Zhai, H.; Hall, D. G. J. Am. Chem. Soc. 2008, 130, 8481-8490. 
114.0, 72.8, 60.9, 42.8, 36.4, 26.9, 25.9, 19.2, 18.1, 14.6, -4.3, -4.5; IR (NaCl plate) 3065, 2951, 2892, 2861, 1642, 1467, 1425, 1254, 1100, 1033, $833 \mathrm{~cm}^{-1}$; HRMS (CI) $m / z:[\mathrm{M}+\mathrm{H}]^{+}$Calcd for $\mathrm{C}_{29} \mathrm{H}_{47} \mathrm{O}_{2} \mathrm{Si}_{2}$ 483.3109; Found 483.3102.

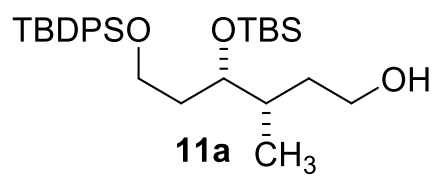

A solution of 9-BBN (17.35 mL, $8.65 \mathrm{mmol}, 0.5 \mathrm{M}$ in THF) was added slowly to the alkene 11 (2.10 g, $4.32 \mathrm{mmol})$. The reaction was stirred 24 hours at ambient temperature. The reaction was then cooled to $0^{\circ} \mathrm{C}$ and quenched by careful addition of ethanol (6.7 mL), $\mathrm{NaOH}(4.6$ $\mathrm{mL}, 3 \mathrm{~N}$ solution) and $30 \%$ aqueous $\mathrm{H}_{2} \mathrm{O}_{2}$ solution $(6 \mathrm{~mL})$. The aqueous layer was extracted with diethyl ether (3 x $200 \mathrm{~mL}$ ). The organic layers were combined, dried over anhydrous magnesium sulfate, filtered, and concentrated in vacuo. Flash chromatography of the crude product (silica gel, $30 \%$ ethyl acetate/hexanes) provided alcohol 11a as a colorless oil. Yield $=1.85 \mathrm{~g}(85 \%) ; \mathrm{R}_{f}=$ $0.43\left(20 \%\right.$ ethyl acetate/hexanes); $[\alpha]_{\mathrm{D}}^{25}-9.5$ (c 1.64, $\left.\mathrm{CHCl}_{3}\right) ;{ }^{1} \mathrm{H}$ NMR $\left(400 \mathrm{MHz}, \mathrm{CDCl}_{3}\right)$

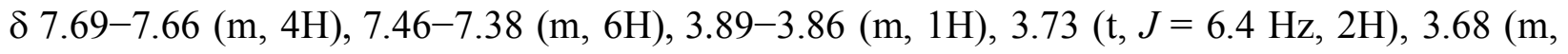
1H), 3.64-3.59 (m, 1H), 2.67 (br s, $1 \mathrm{H}), 1.80-1.74(\mathrm{~m}, 2 \mathrm{H}), 1.70-1.64(\mathrm{~m}, 2 \mathrm{H}), 1.40-1.36(\mathrm{~m}$, 1H), $1.07(\mathrm{~s}, 9 \mathrm{H}), 0.88(\mathrm{~s}, 9 \mathrm{H}), 0.88(\mathrm{~d}, J=6.8 \mathrm{~Hz}, 3 \mathrm{H}), 0.09(\mathrm{~s}, 3 \mathrm{H}), 0.04(\mathrm{~s}, 3 \mathrm{H}) ;{ }^{13} \mathrm{C} \mathrm{NMR}(100$ $\left.\mathrm{MHz}, \mathrm{CDCl}_{3}\right) \delta 135.7,134.2,129.7,127.8,73.2,62.2,60.2,37.6,35.6,35.1,27.1,26.1,19.4$, 18.2, 17.3, -3.8, -4.5; IR (NaCl plate) 3346 (br), 3063, 2945, 2864, 1468, 1429, 1387, 1253, 1100, $835 \mathrm{~cm}^{-1}$; HRMS (CI) m/z: [M+Na] ${ }^{+}$Calcd for $\mathrm{C}_{29} \mathrm{H}_{48} \mathrm{O}_{3} \mathrm{NaSi}_{2}$ 523.3040; Found 523.3039. 


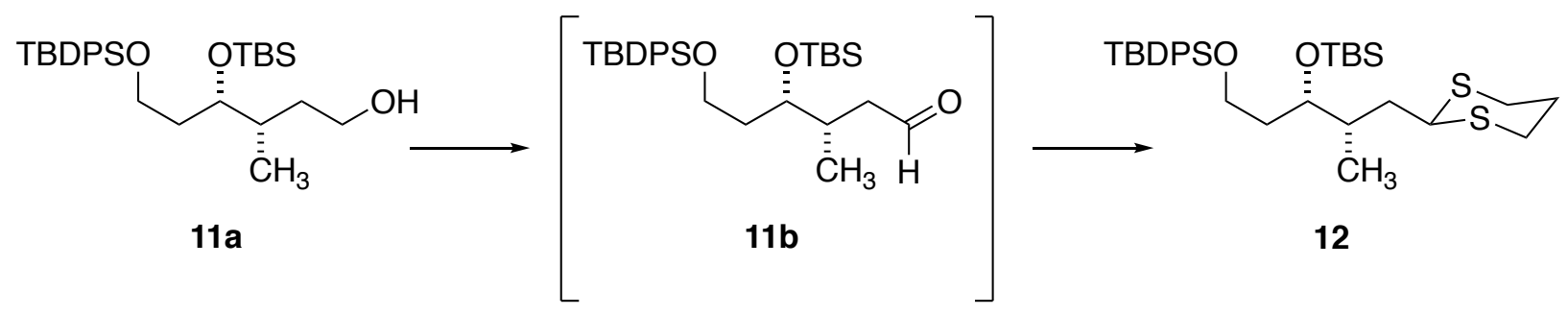

A 4-neck roundbottom flask equipped with stir bar, thermometer, and addition funnel was charged with dry dichloromethane $(120 \mathrm{~mL})$. The flask was cooled at $-78{ }^{\circ} \mathrm{C}$ followed by the addition of oxalyl chloride ( $2 \mathrm{~mL}, 24 \mathrm{mmol})$. DMSO $(3.4 \mathrm{~mL}, 48 \mathrm{mmol})$ was added slowly via addition funnel preventing the reaction temperature from rising above $-60{ }^{\circ} \mathrm{C}$. The mixture was stirred at $-78{ }^{\circ} \mathrm{C}$ for 10 minutes, and a solution of alcohol $11(10 \mathrm{~g}, 20 \mathrm{mmol})$ in dichloromethane $(20 \mathrm{~mL})$ was added slowly preventing the reaction temperature from rising above $-60{ }^{\circ} \mathrm{C}$. The reaction was stirred for $1 \mathrm{~h}$ at $-78^{\circ} \mathrm{C}$. Triethylamine $(11 \mathrm{~mL}, 78.6 \mathrm{mmol})$ was then added slowly via an addition funnel. The reaction was allowed to reach room temperature with continuous stirring until completion. Water was added to the reaction mixture and the layers separated. The aqueous layer was extracted twice with dichloromethane. The combined organic extracts were dried over anhydrous magnesium sulfate, filtered, and the solvent was evaporated at reduced pressure. The crude aldehyde was dissolved with a $25 \%$ diethyl ether solution in pentane followed by filtration, and the solvent was removed at reduced pressure. This process was repeated to remove the ammonium chloride salt and yielded $10 \mathrm{~g}$ of crude aldehyde. This product was used without further purification. However, on one occasion, an aliquot sample was filtered through a short column of silica gel ( $5 \%$ EtOAc/hexanes) to obtain material for characterization: $\mathrm{R}_{f}=0.38$ $\left(5 \%\right.$ ethyl acetate/hexane); $[\alpha]_{\mathrm{D}}^{25}-9.5\left(c\right.$ 1.64, $\left.\mathrm{CHCl}_{3}\right) ;{ }^{1} \mathrm{H} \mathrm{NMR}\left(400 \mathrm{MHz}, \mathrm{CDCl}_{3}\right) \delta 9.73(\mathrm{~s}, 1 \mathrm{H})$, 7.67-7.64 (m, 4H), 7.43-7.36 (m, 6H), 3.85-3.81 (m, 1H), 3.70 (t, J=5.6 Hz, 2H), 2.59-2.54 (m, 1H), 2.27-2.12 (m, 2H), 1.69-1.61 (m, 1H), 1.55-1.45 (m, 1H), $1.05(\mathrm{~s}, 9 \mathrm{H}), 0.87(\mathrm{~d}, J=6.8 \mathrm{~Hz}$ 
3H), $0.84(\mathrm{~s}, 9 \mathrm{H}), 0.03(\mathrm{~s}, 3 \mathrm{H}), 0.00(\mathrm{~s}, 3 \mathrm{H}) ;{ }^{13} \mathrm{C} \mathrm{NMR}\left(100 \mathrm{MHz}, \mathrm{CDCl}_{3}\right) \delta 203.0,135.8,134.0$, $129.9,127.9,72.1,61.1,46.7,35.6,33.8,27.1,26.1,19.4,18.2,15.5,-4.2,-4.5 ; \mathrm{IR}$ (NaCl plate) 3066, 2946, 2898, 2863, 1709, 1644, 1514, 1463, 1425, 1100, 1041, $833 \mathrm{~cm}^{-1}$; HRMS (CI) m/z: $[\mathrm{M}+\mathrm{Na}]^{+}$Calcd for $\mathrm{C}_{29} \mathrm{H}_{46} \mathrm{O}_{3} \mathrm{NaSi}_{2}$ 521.2883; Found 521.2894.

In general, the crude aldehyde (10 g, $20 \mathrm{mmol})$ was dissolved with dry diethyl ether (100 $\mathrm{mL})$. A solution of magnesium bromide diethyl etherate $(7.55 \mathrm{~g}, 41 \mathrm{mmol})$ in diethyl ether (200 $\mathrm{mL}$ ) was added to the reaction mixture and stirred at room temperature. After 2 minutes, 1,3propanedithiol (2.4 mL, $23.9 \mathrm{mmol})$ was added by syringe. After 90 minutes, water was added to quench the reaction. The layers were separated, and the aqueous layer was extracted with diethyl ether $(3 \times 50 \mathrm{~mL})$. The combined organic extracts were dried over anhydrous magnesium sulfate, filtered and the solvent was evaporated at reduced pressure. The product was purified by flash chromatography ( silica gel, gradient of 5-10\% ethyl acetate in hexanes) to give $11.4 \mathrm{~g}$ of dithiane $12\left(95 \%\right.$ for 2 steps). $\mathrm{R}_{f}=0.5\left(20 \%\right.$ ethyl acetate in hexane); $[\alpha]_{\mathrm{D}}^{25}-16.4\left(c 1.66, \mathrm{CHCl}_{3}\right) ;{ }^{1} \mathrm{H}$ NMR (400 MHz, $\left.\mathrm{CDCl}_{3}\right) \delta$ 7.69-7.65 (m, 4H), 7.43-7.35 (m, 6H), 4.08 (dd, J=9.2, 5.6 Hz, 1H), 3.87-3.83 (m, $1 \mathrm{H}), 3.70(\mathrm{t}, J=6.2 \mathrm{~Hz}, 2 \mathrm{H}), 2.91-2.78(\mathrm{~m}, 4 \mathrm{H}), 2.13-2.08(\mathrm{~m}, 1 \mathrm{H}), 2.08-1.85(\mathrm{~m}$, 3H), 1.67-1.48 (m, 3H), $1.06(\mathrm{~s}, 9 \mathrm{H}), 0.86(\mathrm{~s}, 9 \mathrm{H}), 0.84(\mathrm{~d}, J=6.8 \mathrm{~Hz}, 3 \mathrm{H}), 0.07(\mathrm{~s}, 3 \mathrm{H}), 0.01$ (s, $3 \mathrm{H}) ;{ }^{13} \mathrm{C} \mathrm{NMR}\left(100 \mathrm{MHz}, \mathrm{CDCl}_{3}\right) \delta 135.5,133.9,129.5,127.6,71.9,61.0,45.7,37.8,36.0 .34 .8$, $30.6,30.3,26.8,26.1,26.0,19.1,18.0,14.3,-4.3,-4.5 ;$ IR (NaCl plate) 3061, 2942, 2892, 2859, 1466, 1426, 1251, 1101, 1039, $835 \mathrm{~cm}^{-1}$; HRMS (CI) m/z: $\left[\mathrm{M}-\mathrm{CH}_{3}\right]^{+}$Calcd for $\mathrm{C}_{31} \mathrm{H}_{49} \mathrm{O}_{2} \mathrm{~S}_{2} \mathrm{Si}_{2}$ 573.2707; Found 573.2729. HRMS (ESI) $m / z$ : $[\mathrm{M}+\mathrm{Na}]^{+}$Calcd for $\mathrm{C}_{31} \mathrm{H}_{52} \mathrm{O}_{2} \mathrm{~S}_{2} \mathrm{Si}_{2} \mathrm{Na} 611.2845$; Found 611.2842. 


\section{Synthesis Route to Epoxide 13.}
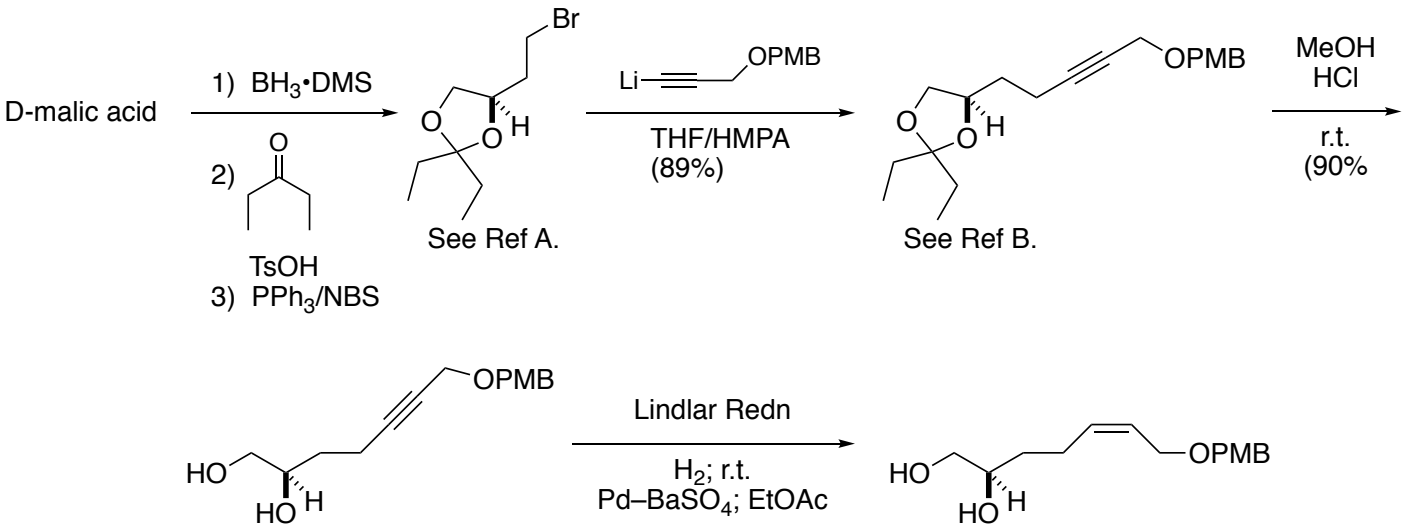

Ref A. Hiroya, K.; Takahashi, T.; Shimomae, K.; Sakamoto, T. Chem. Pharm. Bull. 2005, 53, 207-213.

Ref B. Maezaki, N.; Kojima, N.; Sakamoto, A.; Tominaga, H.; Iwata, C.; Tanaka, T.; Monden, M.;

Damdinsuren, B.; Nakamori, S. Chem. Eur. J. 2003, 9, 390-399.

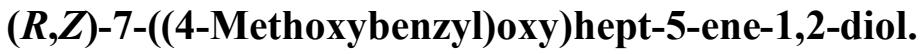

The alkyne diol $(2.4 \mathrm{~g} ; 9.1 \mathrm{mmol})$ was dissolved in ethyl acetate and distilled quinoline (1.5 mL) was added followed by $\mathrm{Pd}_{\text {or }} \mathrm{BaSO}_{4}(500 \mathrm{mg})$ (Lindlar catalyst). The flask was equipped with a 3-way adapter with an attached balloon. The system was flushed with argon, and then the atmosphere was replaced by exchange (3 times) with hydrogen gas which inflated the balloon. The reaction was stirred at room temperature for 1 hour, and was initially monitored by taking aliquots for ${ }^{1} \mathrm{H}$ NMR analysis. Reaction times exceeding one hour produce over-reduction to the saturated byproduct. The experiment can be monitored by tlc since the starting alkyne is detected as a reddish spot while the cis-alkene stains blue using PAA stain ( $p$ anisaldehyde/EtOH/HOAc/ $\mathrm{H}_{2} \mathrm{SO}_{4}$ ). Upon completion, the reaction mixture was filtered through celite and solvent was evaporated under reduced pressure. The crude cis-alkene was purified by flash chromatography on silica gel (10\% EtOAc in pentane) giving a 2.38 (8.9 mmol) (95\% yield)

of the desired product as a thick oil: $[\alpha]_{D}^{22}+9.23\left(c 0.975, \mathrm{CHCl}_{3}\right) ;{ }^{1} \mathrm{H} \mathrm{NMR}\left(400 \mathrm{MHz}, \mathrm{CDCl}_{3}\right) \delta$ $7.27(\mathrm{~d}, J=8.6 \mathrm{~Hz}, 2 \mathrm{H}), 6.88(\mathrm{~d}, J=8.6 \mathrm{~Hz}, 2 \mathrm{H}), 5.64(\mathrm{~m}, 2 \mathrm{H}), 4.45(\mathrm{~s}, 2 \mathrm{H}), 4.02(\mathrm{dq}, J=11.4$, $6.3 \mathrm{~Hz}, 2 \mathrm{H}), 3.80(\mathrm{~s}, 3 \mathrm{H}), 3.65(\mathrm{sp}, J=4.0 \mathrm{~Hz}, 1 \mathrm{H}), 3.55(\mathrm{dd}, J=11.0,2.8 \mathrm{~Hz}, 1 \mathrm{H}), 3.38(\mathrm{dd}, J=$ 
11.0, 7.7 Hz, 1H), $3.09(\mathrm{~s}, 1 \mathrm{H}), 2.41(\mathrm{~s}, 1 \mathrm{H}), 2.28(\mathrm{~m}, 1 \mathrm{H}), 2.14(\mathrm{~m}, 1 \mathrm{H}), 1.48(\mathrm{~m}, 2 \mathrm{H}) ;{ }^{13} \mathrm{C} \mathrm{NMR}$ $\left(100 \mathrm{MHz}, \mathrm{CDCl}_{3}\right) \delta 159.3,134.0,130.0,129.6,126.3,113.8,72.1,70.8,66.7,65.0,55.2$ 32.2, 23.5; IR ( $\mathrm{NaCl}$ plate) 3375, 2933, 2865, 1612, 1515, 1457, 1303, 1248, 1033, $820 \mathrm{~cm}^{-1}$; HRMS (CI) $m / z:[\mathrm{M}-\mathrm{H}]^{+}$Calcd for $\mathrm{C}_{15} \mathrm{H}_{21} \mathrm{O}_{4}$ 265.1434; Found 265.1435.

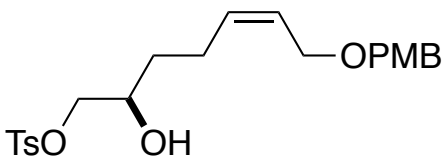

The diol $(2.38 \mathrm{~g}, 8.9 \mathrm{mmol})$ was dissolved in pyridine $(20 \mathrm{~mL})$ and cooled to $-15{ }^{\circ} \mathrm{C}$. The p-toluenesulfonyl chloride $(1.88 \mathrm{~g}, 9.7 \mathrm{mmol})$ was divided in three portions and each portion was added at 30 minute intervals. After complete addition of $p$-toluenesulfonyl chloride, the reaction was stirred for an additional $3.5 \mathrm{~h}$ ( $4.5 \mathrm{~h}$ total time). The mixture was then diluted with ethyl acetate $(60 \mathrm{~mL})$ and the reaction quenched with water $(100 \mathrm{~mL})$. The layers were separated and the aqueous layer was extracted one more time with ethyl acetate. The combined organic layers were washed with aqueous $1 \mathrm{M} \mathrm{HCl}$, and then dried over anhydrous sodium sulfate. The crude product was purified by flash chromatography (silica gel) using $80 \%$ ether/pentane as the eluent affording $2.91 \mathrm{~g}$ of alcohol as a colorless oil $(77 \%$ yield $) .[\alpha]_{D}^{22}+2.54\left(c 0.63, \mathrm{CHCl}_{3}\right) ;{ }^{1} \mathrm{H} \mathrm{NMR}$ $\left(400 \mathrm{MHz}, \mathrm{CDCl}_{3}\right) \delta 7.79(\mathrm{~d}, J=8.2 \mathrm{~Hz}, 2 \mathrm{H}), 7.34(\mathrm{~d}, J=7.9 \mathrm{~Hz}, 2 \mathrm{H}), 7.26(\mathrm{~d}, J=8.6 \mathrm{~Hz}, 2 \mathrm{H})$, $6.88(\mathrm{~d}, J=8.6 \mathrm{~Hz}, 2 \mathrm{H}), 5.66(\mathrm{~m}, 1 \mathrm{H}), 5.54(\mathrm{~m}, 1 \mathrm{H}), 4.44(\mathrm{~d}, J=1.6 \mathrm{~Hz}, 2 \mathrm{H}), 3.86-4.08(\mathrm{~m}, 4 \mathrm{H})$, $3.82(\mathrm{~m}, 1 \mathrm{H}), 3.81(\mathrm{~s}, 3 \mathrm{H}), 2.63(\mathrm{~d}, J=4.8 \mathrm{~Hz}, 1 \mathrm{H}), 2.45(\mathrm{~s}, 3 \mathrm{H}), 2.25(\mathrm{~m}, 1 \mathrm{H}), 2.13(\mathrm{~m}, 1 \mathrm{H})$, 1.44-1.49 (m, 2H); ${ }^{13} \mathrm{C}$ NMR $\left(100 \mathrm{MHz}, \mathrm{CDCl}_{3}\right) \delta 145.0,133.1,132.7,130.0,129.9,129.5,128.0$, 127.0, 113.8, 77.2, 73.7, 72.1, 68.0, 64.9, 55.3, 31.9, 23.2, 21.6; IR (NaCl plate) 3443, 3008, 2935 , 2864, 1612, 1515, 1455, 1358, 1248, 1176, 1096, 1034, 967, $816 \mathrm{~cm}^{-1} ;$ HRMS (CI) m/z: [M-H $]^{+}$ Calcd for $\mathrm{C}_{22} \mathrm{H}_{27} \mathrm{O}_{6} \mathrm{~S} 419.1523$; Found 419.1530. 


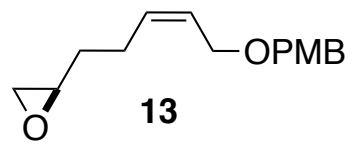

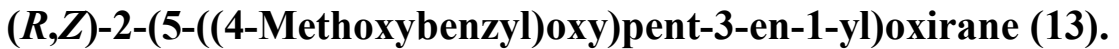

The alcohol, described above, $(2.8 \mathrm{~g}, 6.6 \mathrm{mmol})$ was dissolved in $\mathrm{MeOH}(66 \mathrm{~mL})$ and solid potassium carbonate $(2.8 \mathrm{~g})$ was added. After $35 \mathrm{~min}$, the reaction mixture was filtered, diluted with methylene chloride and aqueous brine. The layers were separated, and the aqueous layer was extracted with methylene chloride $(2 \times 50 \mathrm{~mL})$. The combined organic layers were dried over anhydrous sodium sulfate and the solvent removed under reduced pressure. The crude epoxide was purified by flash chromatography (silica gel) using a 40\% ether/pentane eluent affording 1.38 $\mathrm{g}$ of the desired epoxide 13 as a colorless liquid (83\% yield). $[\alpha]_{D}^{22}+3.4\left(c 0.75, \mathrm{CHCl}_{3}\right) ;{ }^{1} \mathrm{H} \mathrm{NMR}$ $\left(400 \mathrm{MHz}, \mathrm{CDCl}_{3}\right) \delta 7.27(\mathrm{~d}, J=8.2 \mathrm{~Hz}, 2 \mathrm{H}), 6.88(\mathrm{~d}, J=8.4 \mathrm{~Hz}, 2 \mathrm{H}), 5.63(\mathrm{~m}, 2 \mathrm{H}), 4.45(\mathrm{~s}, 2 \mathrm{H})$, $4.06(\mathrm{~d}, J=5.5 \mathrm{~Hz}, 2 \mathrm{H}), 3.81(\mathrm{~s}, 3 \mathrm{H}), 2.91(\mathrm{~m}, 1 \mathrm{H}), 2.74(\mathrm{dd}, J=4.6,4.2 \mathrm{~Hz}, 1 \mathrm{H}), 2.47(\mathrm{dd}, J=$ 4.8, 2.6 Hz, 1H), $2.22(\mathrm{q}, J=7.3 \mathrm{~Hz}, 2 \mathrm{H}), 1.61(\mathrm{~m}, 2 \mathrm{H}) ;{ }^{13} \mathrm{C} \mathrm{NMR}\left(100 \mathrm{MHz}, \mathrm{CDCl}_{3}\right) \delta 159.2$, 132.0, 130.4, 129.4, 127.1, 113.7, 71.8, 65.3, 55.2, 51.7, 47.0, 32.3, 24.1; HRMS (CI) m/z: [M] ${ }^{+}$ Calcd for $\mathrm{C}_{15} \mathrm{H}_{20} \mathrm{O}_{3} 247.1329$; Found 247.1329.

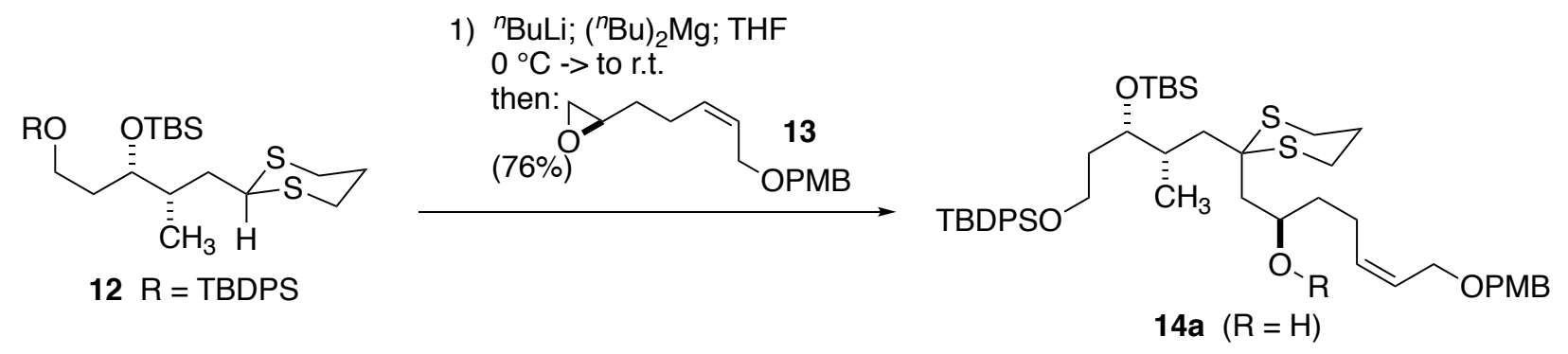

(R,Z)-1-(2-((2S,3S)-3-(Tert-butyldimethylsilyloxy)-5-(tert-butyldiphenylsiloxy)-2-

methylpentyl)-1,3-dithian-2-yl)-7-(4-methoxybenzyloxy)hept-5-en-2-ol (14a).

${ }^{n} \mathrm{Bu}_{2} \mathrm{Mg}(96 \mu \mathrm{L}, 0.096 \mathrm{mmol}, 1.0 \mathrm{M}$ in heptane $)$ was added to ${ }^{n} \mathrm{BuLi}(0.31 \mathrm{~mL}, 0.39 \mathrm{mmol}$, 2.5 $\mathrm{M}$ in hexanes) at $0{ }^{\circ} \mathrm{C}$ and stirred for 5 minutes. To this mixture, a solution of dithiane 12 
(208.7 mg, $0.35 \mathrm{mmol})$ in THF (2 mL) was added and stirred for 35 minutes at room temperature. The solution changed from colorless to yellow. Epoxide 13 (43.4 mg, $0.18 \mathrm{mmol})$ in THF (1 mL) solution was added and stirred for 3 hours. The reaction was quenched with saturated aqueous sodium bicarbonate solution $(2 \mathrm{~mL})$ and extracted with ethyl acetate $(3 \times 5 \mathrm{~mL})$. The combined organic layers were dried over anhydrous magnesium sulfate, filtered, and concentrated in vacuo. Flash chromatography ( silica gel) of the crude product ( $40 \%$ diethyl ether/pentane) provided the alcohol 14a as a colorless oil. Yield $=534 \mathrm{mg}(76 \%) ; \mathrm{R}_{f}=0.29(40 \%$ ethyl acetate/hexanes); $[\alpha]_{\mathrm{D}}^{25}-1.9\left(c 0.93, \mathrm{CHCl}_{3}\right) ;{ }^{1} \mathrm{H} \mathrm{NMR}\left(400 \mathrm{MHz}, \mathrm{CDCl}_{3}\right) \delta 7.69(\mathrm{ddt}, J=7.9,3.3,1.7 \mathrm{~Hz}, 4 \mathrm{H})$, 7.47-7.31 (m, 6H), 7.31-7.23 (m, 2H), 6.98-6.70 (m, 2H), 5.60 (q, J=6.4, 5.9 Hz, 2H), $4.45(\mathrm{~s}$, 2H), 4.14-4.05 (m, 2H), 4.05-3.95 (m, 1H), $3.84(\mathrm{td}, J=5.2,2.7 \mathrm{~Hz}, 1 \mathrm{H}), 3.80(\mathrm{~s}, 3 \mathrm{H}), 3.70(\mathrm{q}, J$ $=6.3 \mathrm{~Hz}, 2 \mathrm{H}), 3.63(\mathrm{dd}, J=2.1,1.0 \mathrm{~Hz}, 1 \mathrm{H}), 2.96(\mathrm{dddd}, J=17.0,14.2,9.7,3.0 \mathrm{~Hz}, 2 \mathrm{H}), 2.84-$ $2.67(\mathrm{~m}, 2 \mathrm{H}), 2.38(\mathrm{dd}, J=15.2,9.3 \mathrm{~Hz}, 1 \mathrm{H}), 2.20(\mathrm{q}, J=6.8,6.4 \mathrm{~Hz}, 2 \mathrm{H}), 2.11-1.94(\mathrm{~m}, 3 \mathrm{H})$, $1.92-1.66(\mathrm{~m}, 4 \mathrm{H}), 1.66-1.50(\mathrm{~m}, 2 \mathrm{H}), 1.48-1.35(\mathrm{~m}, 1 \mathrm{H}), 1.07(\mathrm{~s}, 9 \mathrm{H}), 1.02(\mathrm{~d}, J=6.8 \mathrm{~Hz}, 3 \mathrm{H})$, $0.87(\mathrm{~s}, 9 \mathrm{H}), 0.08(\mathrm{~s}, 3 \mathrm{H}), 0.02(\mathrm{~s}, 3 \mathrm{H}) ;{ }^{13} \mathrm{C} \mathrm{NMR}\left(100 \mathrm{MHz}, \mathrm{CDCl}_{3}\right) \delta 159.3,135.8,134.1,133.2$ $130.7,129.7,129.6,127.8,126.9,114.0,74.4,72.0,67.8,65.7,61.3,55.4,53.3,47.0,44.1,37.7$, $37.1,34.9,27.1,26.9,26.5,26.2,24.8,23.9,19.4,18.4,16.8,-3.9,-4.0 ;$ IR (NaCl plate) 3452 (br), 2953, 2929, 2856, 1728, 1655, 1613, 1588, 1514, 1472, 1463, 1428, 1302, 1249, 1173, 1111 , 1085, 1038, 1007, 939, $836 \mathrm{~cm}^{-1}$; HRMS (ESI) $\mathrm{m} / z$ : $[\mathrm{M}+\mathrm{Na}]^{+}$Calcd for $\mathrm{C}_{47} \mathrm{H}_{72} \mathrm{O}_{5} \mathrm{~S}_{2} \mathrm{Si}_{2} \mathrm{Na}$ 859.4257; Found 859.4232. 

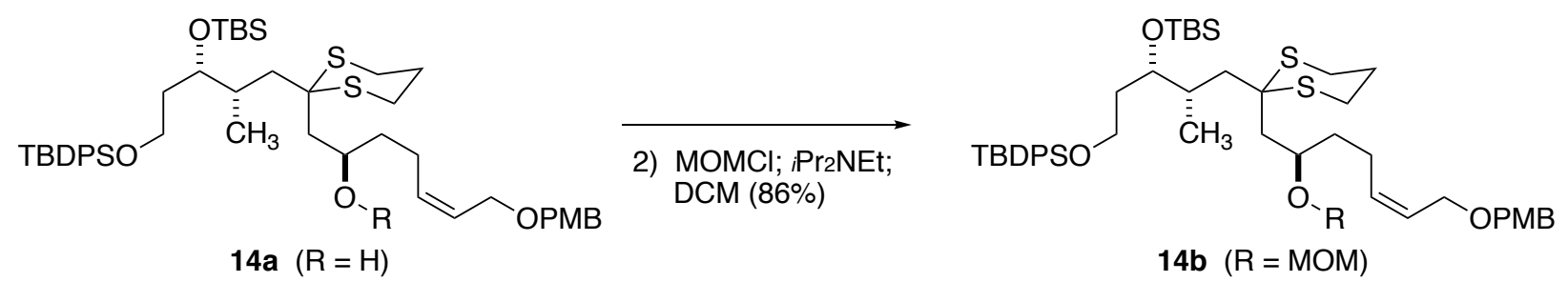

(R,Z)-1-(2-((2S,3S)-3-Tert-butyldimethylsilyloxy)-5-(tert-butyldiphenylsiloxy)-2-

methylpentyl)-1,3-dithian-2-yl)-7-(4-methoxybenzyloxy)hept-5-en-2-ol (14b)

To a solution of the alcohol 14a $(386 \mathrm{mg}, 0.46 \mathrm{mmol})$ in dichloromethane $(5 \mathrm{~mL})$ at $0{ }^{\circ} \mathrm{C}$ were added ${ }^{i} \operatorname{Pr}_{2} \mathrm{NEt}(1.6 \mathrm{~mL}, 9.228 \mathrm{mmol})$ and $\mathrm{MOMCl}(0.35 \mathrm{~mL}, 4.6 \mathrm{mmol})$. The reaction was allowed to warm to ambient temperature and stirred overnight. The reaction was quenched with saturated aqueous sodium bicarbonate solution $(3 \mathrm{~mL})$ and diluted with dichloromethane $(20 \mathrm{~mL})$. The organic layer was separated, and the aqueous layer was extracted with dichloromethane $(3 \mathrm{x}$ $10 \mathrm{~mL}$ ). The combined organic layers were dried over anhydrous magnesium sulfate, filtered, and concentrated in vacuo. Flash chromatography (silica gel) of the crude product (10\% ethyl acetate/hexanes) provided the MOM ether $\mathbf{1 4 b}$ as a colorless oil. Yield $=346 \mathrm{mg}(86 \%) ; \mathrm{R}_{f}=0.21$ (20\% ethyl ether/pentane); $[\alpha]_{\mathrm{D}}^{25}-55.1\left(c 0.80, \mathrm{CHCl}_{3}\right) ;{ }^{1} \mathrm{H} \mathrm{NMR}\left(400 \mathrm{MHz}, \mathrm{CDCl}_{3}\right) \delta 7.68(\mathrm{ddd}$, $J=7.8,3.3,1.6 \mathrm{~Hz}, 4 \mathrm{H}), 7.39(\mathrm{dddd}, J=12.0,9.8,5.8,2.2 \mathrm{~Hz}, 6 \mathrm{H}), 7.32-7.18(\mathrm{~m}, 2 \mathrm{H}), 6.93-6.80$ (m, 2H), $5.61(\mathrm{td}, J=4.1,2.2 \mathrm{~Hz}, 2 \mathrm{H}), 4.84-4.74(\mathrm{~m}, 1 \mathrm{H}), 4.65-4.54(\mathrm{~m}, 1 \mathrm{H}), 4.45(\mathrm{~s}, 2 \mathrm{H}), 4.08$ $(\mathrm{d}, J=4.5 \mathrm{~Hz}, 2 \mathrm{H}), 3.95-3.88(\mathrm{~m}, 1 \mathrm{H}), 3.85(\mathrm{p}, J=2.8 \mathrm{~Hz}, 1 \mathrm{H}), 3.80(\mathrm{~s}, 3 \mathrm{H}), 3.70(\mathrm{dt}, J=10.7$, $5.0 \mathrm{~Hz}, 2 \mathrm{H}), 3.37(\mathrm{~s}, 3 \mathrm{H}), 2.79(\mathrm{dq}, J=5.7,3.3,2.5 \mathrm{~Hz}, 4 \mathrm{H}), 2.30-2.10(\mathrm{~m}, 4 \mathrm{H}), 2.07-1.93$ (m, 2H), $1.90(\mathrm{p}, J=6.1 \mathrm{~Hz}, 2 \mathrm{H}), 1.82-1.54(\mathrm{~m}, 5 \mathrm{H}), 1.06(\mathrm{~s}, 9 \mathrm{H}), 1.01(\mathrm{~d}, J=6.8 \mathrm{~Hz}, 3 \mathrm{H}), 0.87(\mathrm{~s}$, 9H), 0.09 (s, 3H), 0.03 (s, 3H); ${ }^{13} \mathrm{C} \mathrm{NMR}\left(100 \mathrm{MHz}, \mathrm{CDCl}_{3}\right) \delta$ 159.4, 135.8, 134.2, 133.2, 130.7, $129.8,129.6,127.8,126.8,114.0,96.7,76.0,74.5,72.0,65.8,61.4,56.1,55.5,53.9,46.0,43.8$ $37.2,37.1,35.2,27.1,26.7,26.3,25.1,23.6,19.4,18.4,16.8,-3.8,-4.0$; IR (NaCl plate) 2928, 
$2855,1738,1613,1588,1513,1463,1428,1249,1172,1150,1085,1036 \mathrm{~cm}^{-1} ;$ HRMS (ESI) $\mathrm{m} / z$ : $[\mathrm{M}+\mathrm{Na}]^{+}$Calcd for $\mathrm{C}_{49} \mathrm{H}_{76} \mathrm{O}_{6} \mathrm{NaSi}_{2} \mathrm{~S}_{2}$ 903.4520; Found 903.4550.

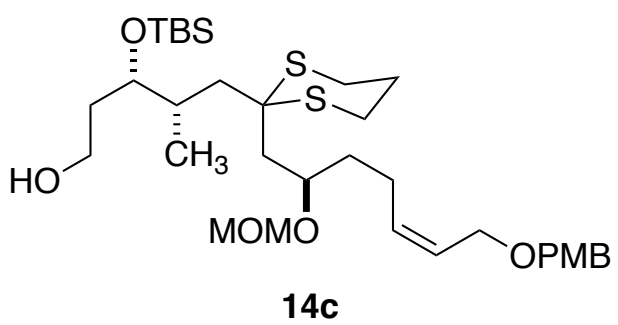

\section{(3S,4S)-3-((Tert-butyldimethylsilyl)oxy)-5-(2-((R,Z)-7-((4-methoxybenzyl)oxy)-2-}

\section{(methoxymethoxy)hept-5-en-1-yl)-1,3-dithian-2-yl)-4-methylpentan-1-ol (14c).}

The starting dithiane $\mathbf{1 4 b}$ (33 $\mathrm{mg}, 0.0375 \mathrm{mmol})$ was dissolved in absolute ethanol $(2 \mathrm{~mL})$ and a solution of $3 \underline{\mathrm{M} \mathrm{KOH}}$ in ethanol $(0.6 \mathrm{~mL})$ was added dropwise at room temperature. The mixture was heated to $55^{\circ} \mathrm{C}$ (oil bath) until starting silyl ether was consumed. Upon cooling, a solution of aqu. $\mathrm{NH}_{4} \mathrm{Cl}$ was added, and the mixture was extracted with EtOAc $(3 \times 5 \mathrm{~mL})$. Solvent was removed and purification by flash chromatography (silica gel, 40\% EtOAc/hexanes) resulted in the isolation of primary alcohol $\mathbf{1 4 c}(18 \mathrm{mg}, 75 \%$ yield $)$. The alcohol $\mathbf{1 4 c}$ was prepared on only two occasions and is not optimized. Partial characterization is available as follows: ${ }^{1} \mathrm{H}$ NMR (400 $\left.\mathrm{Hz}, \mathrm{CDCl}_{3}\right) \delta 7.27(\mathrm{~d}, J=7.0,1.4 \mathrm{~Hz}, 2 \mathrm{H}), 6.92-6.79(\mathrm{~d}, 2 \mathrm{H}), 5.66-5.51(\mathrm{~m}, 2 \mathrm{H}), 4.78(\mathrm{~d}, J=6.8$ $\mathrm{Hz}, 1 \mathrm{H}), 4.62(\mathrm{~d}, J=6.8 \mathrm{~Hz}, 1 \mathrm{H}), 4.44(\mathrm{~s}, 2 \mathrm{H}), 4.07$ (d, $J=4.6 \mathrm{~Hz}, 2 \mathrm{H}), 3.87$ (dd, $J=5.74 .0 \mathrm{~Hz}$, 1H), $3.82(\mathrm{dd}, J=6.5,2.6 \mathrm{~Hz}, 1 \mathrm{H}), 3.80(\mathrm{~s}, 3 \mathrm{H}), 3.69$ (p, $J=5.3,4.9 \mathrm{~Hz}, 2 \mathrm{H}), 3.37$ (s, 3H), 2.79 $(\mathrm{td}, J=5.0,2.9 \mathrm{~Hz}, 4 \mathrm{H}), 2.28(\mathrm{~d}, J=5.6 \mathrm{~Hz}, 1 \mathrm{H}), 2.24(\mathrm{~d}, J=5.7 \mathrm{~Hz}, 1 \mathrm{H}), 2.16(\mathrm{dq}, J=10.8,4.6$ $3.0 \mathrm{~Hz}, 4 \mathrm{H}), 2.06-1.97(\mathrm{~m}, 2 \mathrm{H}), 1.91(\mathrm{q}, J=4.7 \mathrm{~Hz}, 1 \mathrm{H}), 1.81(\mathrm{t}, J=5.4 \mathrm{~Hz}, 1 \mathrm{H}), 1.75-1.61(\mathrm{~m}$, 4H), 1.07-0.96 (m, 3H), $0.90(\mathrm{~s}, 9 \mathrm{H}), 0.11(\mathrm{~s}, 3 \mathrm{H}), 0.09(\mathrm{~s}, 3 \mathrm{H})$; HRMS (EI) $m / z:[\mathrm{M}]^{+}$Calcd for $\mathrm{C}_{33} \mathrm{H}_{58} \mathrm{O}_{6} \mathrm{~S}_{2} \mathrm{Si}$ 642.3444; Found 642.3441. 


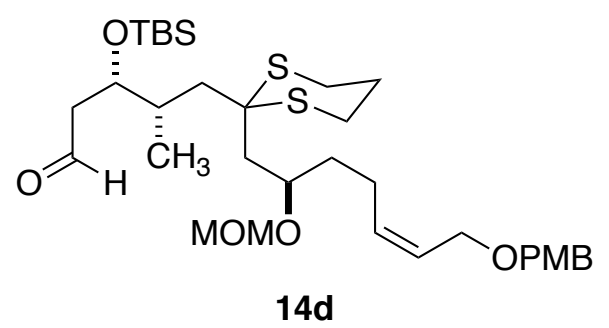

(3S,4S)-3-((Tert-butyldimethylsilyl)oxy)-5-(2-((R,Z)-7-((4-methoxybenzyl)oxy)-2-

(methoxymethoxy)hept-5-en-1-yl)-1,3-dithian-2-yl)-4-methylpentanal (14d).

The starting alcohol (13 mg; $0.02 \mathrm{mmol})$ was dried by azeotropic evaporation of benzene (twice) and dissolved in $\mathrm{CH}_{2} \mathrm{Cl}_{2}(400 \mu \mathrm{L})$. Then dry DMSO $(15 \mu \mathrm{L})$ and diisopropylethylamine $(18 \mu \mathrm{L})$ were added followed by the introduction of $\mathrm{SO}_{3} \bullet$ pyr $(8 \mathrm{mg})$ at $22 \cdot \mathrm{C}$. After stirring for 15 minutes, the reaction was quenched by addition of aqu $\mathrm{NaHCO}_{3}$ solution ( 5 drops). Water and $\mathrm{CH}_{2} \mathrm{Cl}_{2}$ were added $\left(1 \mathrm{~mL}\right.$ each) and after stirring, the separated $\mathrm{CH}_{2} \mathrm{Cl}_{2}$ phase was removed by syringe. This extraction was repeated with additional $\mathrm{CH}_{2} \mathrm{Cl}_{2}(1 \mathrm{~mL})$ and the combined organic extracts were concentrated under reduced pressure. The crude product was purified by flash chromatography (silica gel, 40\% EtOAc/hexanes) leading to the isolation of aldehyde 14d (13 mg, 97\% conversion). This experiment was not optimized on a larger scale, and 14d was only submitted for partial characterization before this line of inquiry was discontinued: ${ }^{1} \mathrm{H}$ NMR (400 $\left.\mathrm{Hz}, \mathrm{CDCl}_{3}\right) \delta 9.80(\mathrm{t}, J=2.3 \mathrm{~Hz}, 1 \mathrm{H}), 7.38-7.10(\mathrm{~d}, 2 \mathrm{H}), 6.94-6.75(\mathrm{~d}, 2 \mathrm{H}), 5.60(\mathrm{td}, J=4.2,2.3$ $\mathrm{Hz}, 2 \mathrm{H}), 4.78(\mathrm{~d}, J=6.8 \mathrm{~Hz}, 1 \mathrm{H}), 4.62(\mathrm{~d}, J=6.8 \mathrm{~Hz}, 1 \mathrm{H}), 4.44(\mathrm{~s}, 2 \mathrm{H}), 4.20(\mathrm{ddd}, J=6.7,5.2$, 3.1 Hz, 1H) 4.11-4.02 (m, 2H), $3.88(\mathrm{dd}, J=5.8,4.0 \mathrm{~Hz}, 1 \mathrm{H}), 3.80$ (s, 3H), 3.37 (s, 3H), 2.86$2.71(\mathrm{~m}, 5 \mathrm{H}), 2.63-2.44(\mathrm{~m}, 2 \mathrm{H}), 2.28-2.11(\mathrm{~m}, 4 \mathrm{H}), 2.08-1.95(\mathrm{~m}, 2 \mathrm{H}), 1.91(\mathrm{q}, J=5.4 \mathrm{~Hz}, 2 \mathrm{H})$, 1.83-1.59 (m, 2H), $1.05(\mathrm{~d}, J=6.9 \mathrm{~Hz}, 3 \mathrm{H}), 0.88(\mathrm{~s}, 9 \mathrm{H}), 0.12(\mathrm{~s}, 3 \mathrm{H}), 0.05(\mathrm{~s}, 3 \mathrm{H})$; HRMS (EI) $m / z:[\mathrm{M}]^{+}$Calcd for $\mathrm{C}_{33} \mathrm{H}_{56} \mathrm{O}_{6} \mathrm{~S}_{2} \mathrm{Si}$ 640.3298; Found 640.3294. 

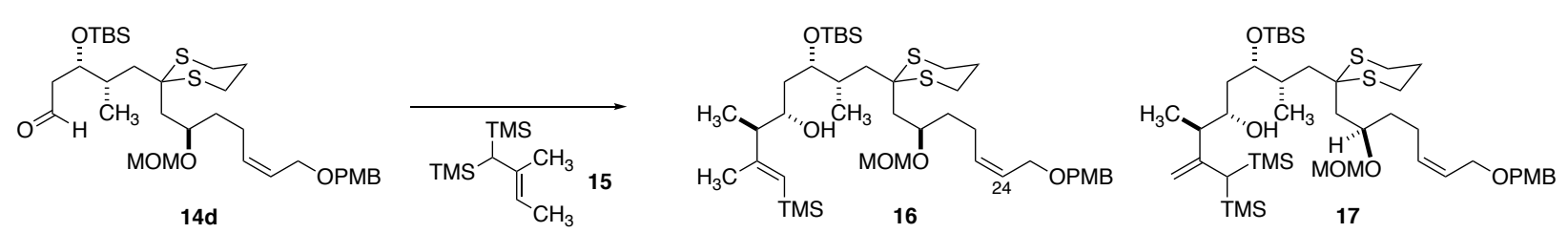

The aldehyde 14d (18 mg) was dried by azeotropic removal of benzene (twice) and dissolved in dry $\mathrm{CH}_{2} \mathrm{Cl}_{2}(200 \mu \mathrm{L})$. Upon cooling under argon atmosphere to $-78{ }^{\circ} \mathrm{C}$, the Lewis acid $\mathrm{Me}_{2} \mathrm{AlCl}$ was introduced as a $1.0 \mathrm{M}$ solution in hexanes $(72 \mu \mathrm{L})$. Within 3 minutes, the allylsilane 15 (6 mg in $50 \mu \mathrm{L}$ of $\left.\mathrm{CH}_{2} \mathrm{Cl}_{2}\right)$ was added to the reaction. After 25 minutes, starting $\mathbf{1 4 d}$ was consumed, and the reaction was quenched by adding several drops of $\mathrm{MeOH}$ and $\mathrm{CH}_{2} \mathrm{Cl}_{2}(2$ $\mathrm{mL}$ ) followed by aqu solution of Rochelle's salt. Stirring was continued until layers were readily separated and the organic layer was removed. Extraction with additional $\mathrm{CH}_{2} \mathrm{Cl}_{2}(1 \mathrm{~mL})$ was followed by combining the organic layers and concentration under reduced pressure which led to a thick oily residue. Purification via flash chromatography (silica gel, 10\% EtOAc/hexanes) afforded a mixture of allylation and ene products which coeluted. The ${ }^{1} \mathrm{H}$ NMR spectrum (SI) is included to indicate the TENTATIVE ASSIGNMENTS TO IDENTIFY the signals for allylation diastereomers and the ene product in this mixture. However, further attempts to improve this reaction were not investigated in favor of the use of bis-epoxide 19 in Scheme 6 . Further investigations of the Synthesis Route of Scheme 2 were terminated at this point.
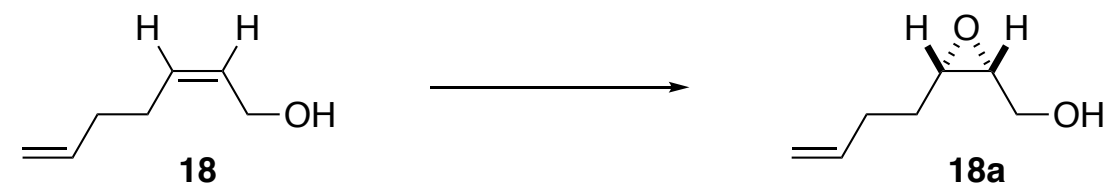

\section{Sharpless Asymmetric Epoxidation of 18.}

Powdered $4 \AA$ molecular sieves $(60 \mathrm{mg})$ were activated by flame drying under high vacuum. To a suspension of dry molecular sieves in dicholoromethane $(24 \mathrm{~mL})$ at $-25^{\circ} \mathrm{C}, \mathrm{D}-(-)-$ diethyl tartrate $(47 \mu \mathrm{L}, 0.273 \mathrm{mmol})$ and titanium isopropoxide $(56 \mu \mathrm{L}, 0.19 \mathrm{mmol})$ were added, 
and the mixture was stirred for $30 \mathrm{~min}$ at this temperature. To this mixture, $t$-butyl hydroperoxide (3.50 mL, $12.96 \mathrm{mmol}, 3.70 \mathrm{M}$ solution in toluene) was added, and the reaction was stirred for an additional $30 \mathrm{~min}$. A solution of (2Z)-2,6-heptadien-1-ol (1.32 g, $11.78 \mathrm{mmol})$ in dichloromethane $(5 \mathrm{~mL})$ was added dropwise over a period of fifteen minutes and stirred for an additional one hour at this temperature. The reaction flask was then sealed and kept in the freezer for three days at $40{ }^{\circ} \mathrm{C}$. The reaction was quenched with aqueous sodium hydroxide solution saturated with sodium chloride $(7 \mathrm{~mL})$ and stirred for $3 \mathrm{~h}$. The organic layer was separated and the aqueous layer was extracted with dichloromethane $(3 \times 50 \mathrm{~mL})$. The combined organic layers were dried over anhydrous magnesium sulfate, filtered, and concentrated in vacuo. Flash chromatography (silica gel) of the crude product (40\% diethyl ether/pentane) provided 2,3-epoxy alcohol 18a as a colorless oil. Mosher ester analysis of the epoxy alcohol indicated a 92:8 ratio of diastereomeric Mosher ester derivatives Yield $=1.27 \mathrm{~g}(84 \%) ; \mathrm{R} f=0.21(50 \%$ diethyl ether in pentane $)$; Yield $=$ $1.27 \mathrm{~g}(84 \%) ; \mathrm{R}_{f}=0.21\left(50 \%\right.$ diethyl ether in pentane); $[\alpha]_{\mathrm{D}}^{25}+10.8\left(c 0.98, \mathrm{CHCl}_{3}\right) ;{ }^{1} \mathrm{H}$ NMR $\left(400 \mathrm{MHz}, \mathrm{CDCl}_{3}\right) \delta 5.85-5.75(\mathrm{~m}, 1 \mathrm{H}), 5.04(\mathrm{~d}, J=17.2 \mathrm{~Hz}, 1 \mathrm{H}), 4.97(\mathrm{~d}, J=17.2 \mathrm{~Hz}, 1 \mathrm{H}), 3.80$ $(\mathrm{dd}, \mathrm{A}$ of $\mathrm{ABX}, \mathrm{JAB}=12.2 \mathrm{~Hz}, \mathrm{JAX}=3.6 \mathrm{~Hz}, 1 \mathrm{H}), 3.63(\mathrm{dd}, \mathrm{B}$ of $\mathrm{AB}, \mathrm{JAB}=12.2 \mathrm{~Hz}, \mathrm{JBX}=6.8$ $\mathrm{Hz}, 1 \mathrm{H}), 3.16-3.12(\mathrm{~m}, 1 \mathrm{H}), 3.05-3.01(\mathrm{~m}, 1 \mathrm{H}), 2.27-2.13(\mathrm{~m}, 2 \mathrm{H}), 1.66-1.59(\mathrm{~m}, 2 \mathrm{H}), 1.29-$ $1.22(\mathrm{~m}, 1 \mathrm{H}) ;{ }^{13} \mathrm{C} \mathrm{NMR}\left(100 \mathrm{MHz}, \mathrm{CDCl}_{3}\right) \delta 137.5,115.6,60.9,57.2,56.9,30.8,27.4 ; \mathrm{IR}(\mathrm{NaCl}$ plate, $\left.\mathrm{cm}^{-1}\right) 3423$ (br), 3075, 2977, 2923, 2866, 1748, 1640, 1448, 1420, 1274, 1037, 913, 878; HRMS (CI) $m / z:[\mathrm{M}+\mathrm{H}]^{+}$Calcd for $\mathrm{C}_{7} \mathrm{H}_{12} \mathrm{O}_{2}$ 129.0910; Found 129.0905. 


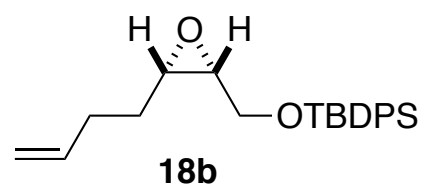

\section{Preparation of Silyl Ether 18b.}

To a solution of the epoxy-alcohol $\mathbf{1 8 a}(750 \mathrm{mg}, 5.85 \mathrm{mmol})$ in dichloromethane $(20 \mathrm{~mL})$ imidazole (796 mg, $11.70 \mathrm{mmol})$ was added, followed by TBDPSCl (1.60 mL, $6.14 \mathrm{mmol})$. The reaction mixture was stirred overnight at ambient temperature and quenched by addition of water. The aqueous layer was separated, and the organic layer was extracted with dichloromethane $(3 \mathrm{x}$ $20 \mathrm{~mL}$ ). The combined organic layers were dried over anhydrous magnesium sulfate, filtered, and concentrated in vacuo. Flash chromatography (silica gel) of the crude product (5\% ethyl acetate/hexanes) provided the alkene $\mathbf{1 8 b}$ as a colorless oil. Yield $=1.99 \mathrm{~g}(93 \%) ; \mathrm{R}_{f}=0.53(5 \%$ ethyl acetate/ hexane); $[\alpha]_{\mathrm{D}}^{25}-2.6\left(c\right.$ 0.78, $\left.\mathrm{CHCl}_{3}\right) ;{ }^{1} \mathrm{H} \mathrm{NMR}\left(400 \mathrm{MHz}, \mathrm{CDCl}_{3}\right) \delta 7.72-7.68(\mathrm{~m}$, 4H), 7.47-7.37 (m, 6H), 5.87-5.74 (m, 1H), 5.07-4.97 (m, 2H), 3.85-3.73 (dd, $J=8.1,5.4 \mathrm{~Hz}$ 2H), 3.20-3.15 (m, 1H), 3.01-2.96 (m, 1H), 2.27-2.14 (m, 2H), 1.55-1.44 (m, 2H), $1.08(\mathrm{~s}, 9 \mathrm{H})$; ${ }^{13} \mathrm{C} \mathrm{NMR}\left(100 \mathrm{MHz}, \mathrm{CDCl}_{3}\right) \delta 137.7,135.8,133.6,133.4,130.0,127.9,115.4,62.4,56.9,56.4$, 31.8, 30.9, 27.0, 19.4; IR ( $\mathrm{NaCl}$ plate) 3071, 3050, 3014, 2959, 2931, 2858, 1473, 1463, 1428 , 1362, 1261, 1113, 914, $823, \mathrm{~cm}^{-1}$; HRMS (ESI) $\mathrm{m} / z$ : $[\mathrm{M}+\mathrm{Na}]^{+}$Calcd for $\mathrm{C}_{23} \mathrm{H}_{30} \mathrm{O}_{2} \mathrm{NaSi} 389.1913$; Found 389.1914.

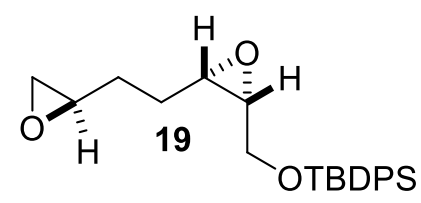

\section{Preparation of 19.}

To a solution of the alkene $\mathbf{1 8 b}(180 \mathrm{mg}, 0.47 \mathrm{mmol})$ in dichloromethane $(1 \mathrm{~mL})$ at ambient temperature the Katsuki catalyst $(S, S)-\mathbf{2 0}(17 \mathrm{mg}, 0.01 \mathrm{mmol})$ was added, followed by $30 \%$ 
aqueous $\mathrm{H}_{2} \mathrm{O}_{2}$ solution $(75 \mu \mathrm{L}, 0.71 \mathrm{mmol})$. The reaction mixture was stirred for 24 hours and diluted with dichloromethane $(5 \mathrm{~mL})$. The organic layer was separated and the aqueous layer was washed with dichloromethane $(3 \times 5 \mathrm{~mL})$. The combined organic layers were dried over anhydrous magnesium sulfate, filtered, and concentrated in vacuo. Flash chromatography (silica gel) of the crude product (15\% ethyl acetate/hexanes) provided the bis-epoxide 19 as a colorless oil. Yield = $124 \mathrm{mg}(66 \%) ; 84 \%(\mathrm{brsm}) ; \mathrm{R}_{f}=0.32(10 \%$ ethyl acetate/hexane mixture $) ;[\alpha]_{\mathrm{D}}^{25}+1.2(c 0.94$, $\left.\mathrm{CHCl}_{3}\right) ;{ }^{1} \mathrm{H} \mathrm{NMR}\left(400 \mathrm{MHz}, \mathrm{CDCl}_{3}\right) \delta$ 7.68-7.67 (m, 4H), 7.41-7.36 (m, 6H), 3.83-3.72 (m, 2H), 3.19-3.14 (m, 1H), 2.99-2.95 (m, 1H), 2.88-2.84 (m, 1H), 2.72-2.69 (m, 1H), 2.44-2.42 (m, 1H), 1.76-1.69 (m, 1H), 1.64-1.54 (m, 2H), 1.51-1.49 (m, 1H), $1.05(\mathrm{~s}, 9 \mathrm{H}) ;{ }^{13} \mathrm{C}$ NMR (100 MHz, $\left.\mathrm{CDCl}_{3}\right) \delta 135.8,133.5,133.3,130.0,127.9,62.2,60.5,56.9,56.4,51.9,47.2,30.0,26.9,24.8$ 19.4; IR (NaCl plate, $\left.\mathrm{cm}^{-1}\right)$ 3071, 3049, 2959, 2931, 2858, 1473, 1428, 1391, 1261, 1112, 1007 , 823; HRMS (CI) $m / z$ : $[\mathrm{M}+\mathrm{Na}]^{+}$Calcd for $\mathrm{C}_{23} \mathrm{H}_{30} \mathrm{O}_{3} \mathrm{NaSi}$ 405.1862; Found 405.1860.

The starting alkene $\mathbf{1 8 b}$ is recovered in $20-25 \%$ yield during the flash chromatography (silica gel) of the bis-epoxide 19. This material was routinely resubmitted to the reaction conditions described above. The recycling of $\mathbf{1 8 b}$ provided $80 \%$ overall conversion to product 19 (after two cycles). The bis-epoxide 19 was estimated to be a 90:10 mixture of diastereomers based upon the measurement of peak heights in the decoupled ${ }^{13} \mathrm{C}$ NMR spectrum.

Additionally, we have used the Jacobsen hydrolytic kinetic resolution (HRK), employing $(R, R)-\mathrm{Co}(\mathrm{II})$ (salen)OAc with the mixture of bis-epoxides (see below). This process afforded samples of 19 that indicated a comparable $91: 9 \mathrm{dr}$ based on our ${ }^{13} \mathrm{C}$ NMR analysis. Thus, the ratio of diastereomers reflects, to a significant degree, the stereoselectivity of the reaction. In practice, the enantioenriched bis-epoxide 19, produced via the Katsuki oxidation, was directly used in 
subsequent reactions followed by the chromatographic separation of the undesired minor diastereomers.

An Example of the Application of the Jacobsen Hydrolytic Kinetic Resolution (HKR).
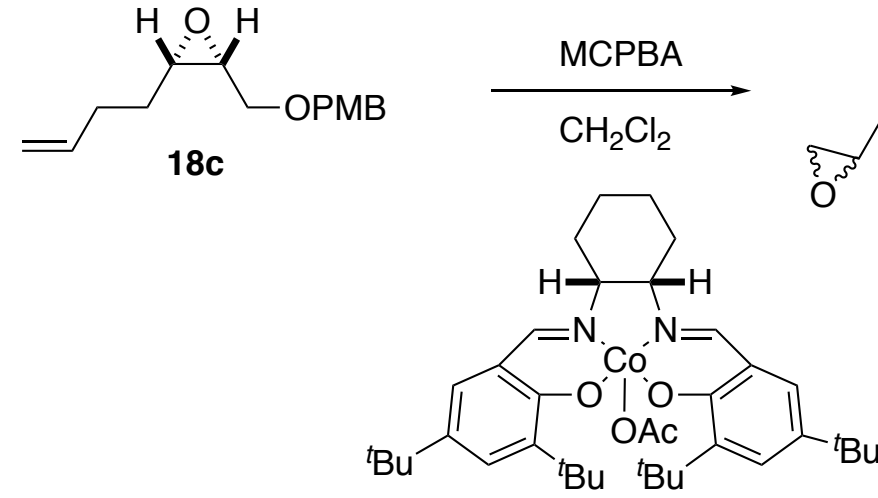

$(R, R)$-catalyst

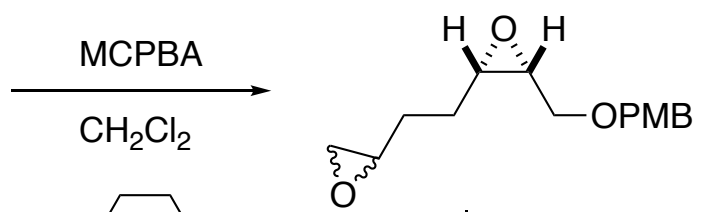

THF, $\mathrm{H}_{2} \mathrm{O}$

r.t.

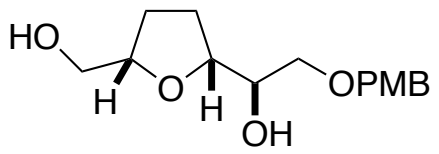

THF product $(46 \%)$

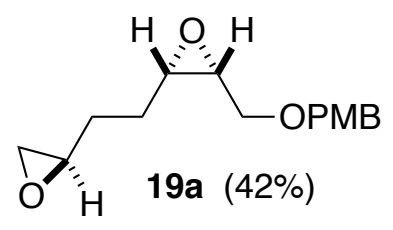

Following the use of Sharpless asymmetric epoxidation and protection to produce 18c, the nonselective oxidation with MCPBA provided a mixture of bis-epoxide diastereomers (3.08 g; $11.66 \mathrm{mmol}$ ). This mixture was submitted to hydrolytic conditions using the Jacobsen catalyst $(R, R)-\mathrm{Co}(\mathrm{II})$ (salen) OAc $(95.8 \mathrm{mg} ; 0.14 \mathrm{mmol})$ in THF $(3 \mathrm{~mL})$ followed by the introduction of a small amount of $\mathrm{H}_{2} \mathrm{O}(170 \mathrm{mg})$. The reaction was stirred for 24 hours at ambient temperature and led to the recovery of bis-epoxide 19a (PMB derivative) $(42 \%)$ as a clear liquid. The results of several experiments provided samples indicating a ratio of 91:9 dr to as high as 94:6 dr based on our ${ }^{13} \mathrm{C}$ NMR analysis. Spectral information is indistinguishable from data obtained via the Katsuki oxidation of 18c (PMB). Note that the hydrolysis product was characterized as the substituted tetrahydrofuran shown above ( $46 \%$ yield). For complete characterization of bisepoxide 19a (PMB derivative): $[\alpha]_{\mathrm{D}}^{25}-23.8\left(c\right.$ 1.08, $\left.\mathrm{CHCl}_{3}\right) ; \mathrm{R}_{f}=0.23 \quad(20 \%$ ethyl 
acetate/hexanes); ${ }^{1} \mathrm{H}$ NMR (400 MHz, $\left.\mathrm{CDCl}_{3}\right) \delta 7.27(\mathrm{~d}, J=8.4 \mathrm{~Hz}, 2 \mathrm{H}), 6.87(\mathrm{~d}, J=8.4 \mathrm{~Hz})$, $4.55\left(\mathrm{~d}, \mathrm{~A}\right.$ of $\left.\mathrm{AB}, J_{A B}=11.4 \mathrm{~Hz}, 1 \mathrm{H}\right), 4.46\left(\mathrm{~d}, \mathrm{~B}\right.$ of $\left.\mathrm{AB}, J_{A B}=11.4 \mathrm{~Hz}, 1 \mathrm{H}\right), 3.81(\mathrm{~s}, 3 \mathrm{H}), 3.65(\mathrm{dd}$, $\mathrm{A}$ of $\left.\mathrm{ABX}, J_{A B}=10.8 \mathrm{~Hz}, J_{A X}=4.8 \mathrm{~Hz}, 1 \mathrm{H}\right), 3.55\left(\mathrm{dd}, \mathrm{B}\right.$ of $\left.\mathrm{ABX} J_{A B}=10.8 \mathrm{~Hz}, J_{A X}=6.4 \mathrm{~Hz}, 1 \mathrm{H}\right)$, 3.18-3.22 (m, 1H), 2.93-3.05 (m, 2H), 2.76-2.78 (m, 1H), 2.48-2.50 (m, 1H), 1.59-1.86 (m, 4H); ${ }^{13} \mathrm{C} \mathrm{NMR}\left(100 \mathrm{MHz}, \mathrm{CDCl}_{3}\right) \delta 159.5,130.1,129.7,114.7,73.2,67.9,55.9,55.5,55.4$ 52.0, 47.3, 30.0, 25.0; IR (NaCl plate) 2973, 2881, 1465, 1270, 1203, 1173, 1077, $919 \mathrm{~cm}^{-1}$; HRMS (CI) m/z: $[\mathrm{M}]^{+}$Calcd for $\mathrm{C}_{15} \mathrm{H}_{20} \mathrm{O}_{4}$ 264.1356; Found 264.1346.

\section{(R)-1-((2S,5S)-5-(hydroxymethyl)tetrahydrofuran-2-yl)-2-(4-methoxybenzyloxy)ethanol.}

Flash chromatography (silica gel) of the hydrolysis product (50\% ethyl acetate/hexanes) also provided the THF diol as a colorless oil. Yield $=1.41 \mathrm{~g}(46 \%) ; \mathrm{R}_{f}=0.12(50 \%$ ethyl acetate/hexanes); $[\alpha]_{\mathrm{D}}^{25}-56.0\left(\mathrm{c} 1.16, \mathrm{CHCl}_{3}\right) ;{ }^{1} \mathrm{H} \mathrm{NMR}\left(400 \mathrm{MHz}, \mathrm{CDCl}_{3}\right) \delta 7.23(\mathrm{~d}, J=8.4 \mathrm{~Hz}$, 2H), $6.86(\mathrm{~d}, J=8.4 \mathrm{~Hz}, 2 \mathrm{H}), 4.47(\mathrm{~m}, 2 \mathrm{H}), 4.12-4.07(\mathrm{~m}, 1 \mathrm{H}), 4.00-3.95(\mathrm{~m}, 1 \mathrm{H}), 3.78(\mathrm{~s}, 3 \mathrm{H})$, 3.68-3.62 (m, 2H), 3.52-3.43 (m, 3H), 2.69 (br s, 1H), 2.25 (br s, 1H), 1.98-1.90 (m, 2H), 1.81$1.72(\mathrm{~m}, 2 \mathrm{H}) ;{ }^{13} \mathrm{C}$ NMR $\left(100 \mathrm{MHz}, \mathrm{CDCl}_{3}\right) \delta 159.5,130.2,129.6,114.0,80.1,79.9,77.4,73.3$, 73.0, 71.6, 65.0, 55.5, 28.5, 27.8; IR (NaCl plate) 3432 (br), 3036, 2922, 2881, 1513, 1461, 1303, 1246, 1175, $1039 \mathrm{~cm}^{-1}$; HRMS (CI) $m / z$ : $[\mathrm{M}+\mathrm{Na}]^{+}$Calcd for $\mathrm{C}_{15} \mathrm{H}_{22} \mathrm{O}_{5} \mathrm{Na}$ 305.1365; Found 305.1350 .

An experiment for application of HKR to the bis-epoxide 19 (TBDPS) provided similar results, and we chose to adopt the Katsuki reaction for improved conservation of mass in the conversion to bis-epoxide 19. 


\section{Scheme 6 SI Content}

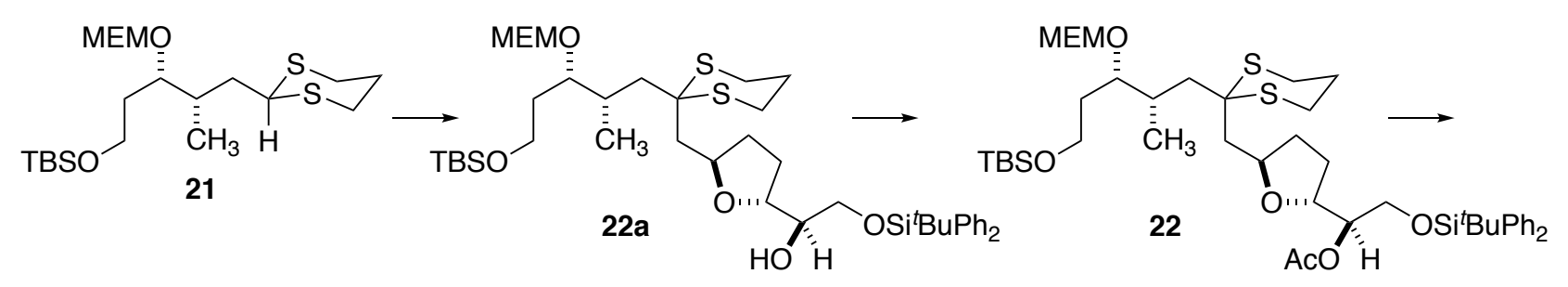

MEMO

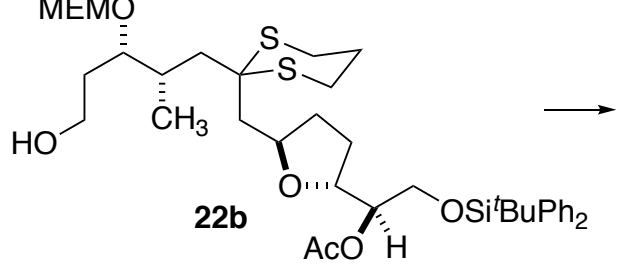

MEMO

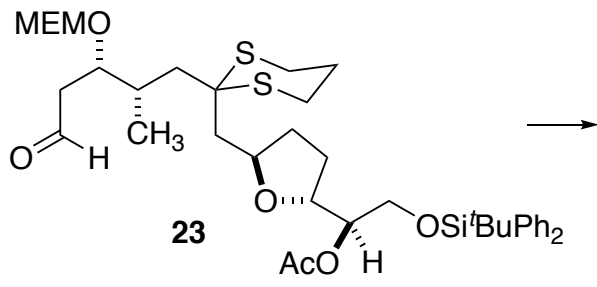

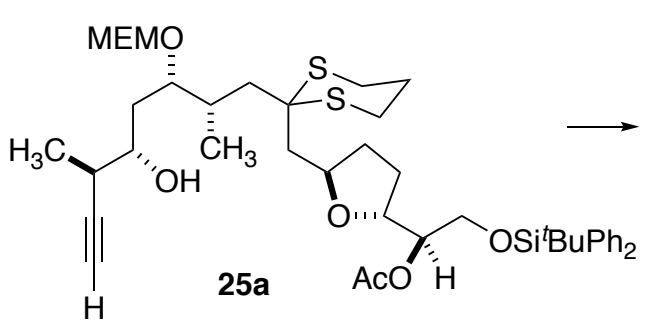

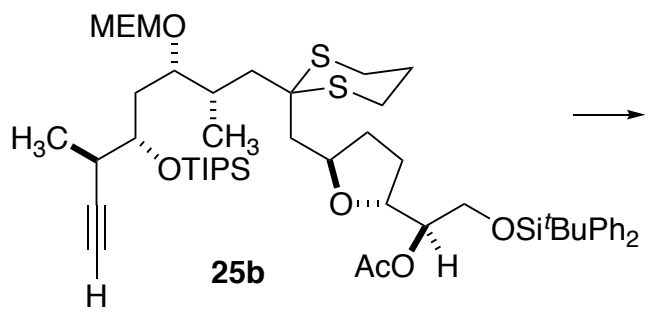

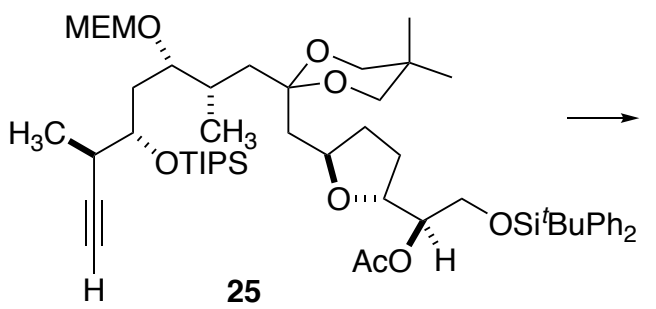

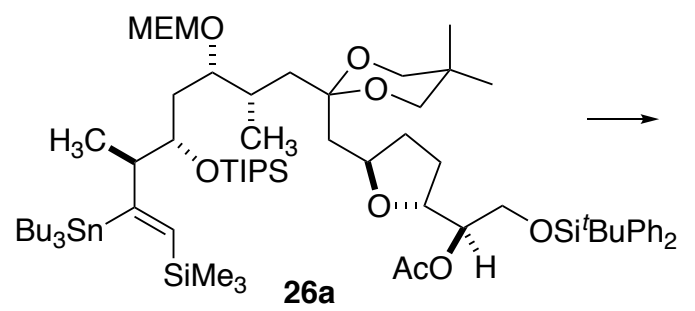

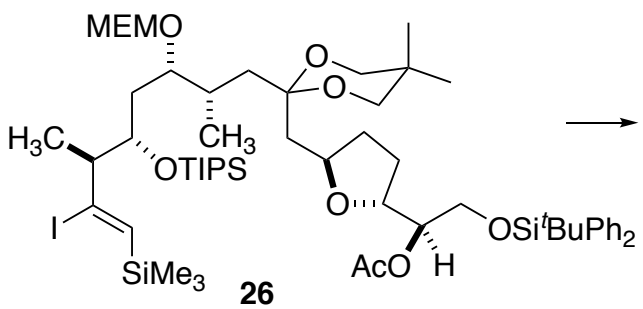

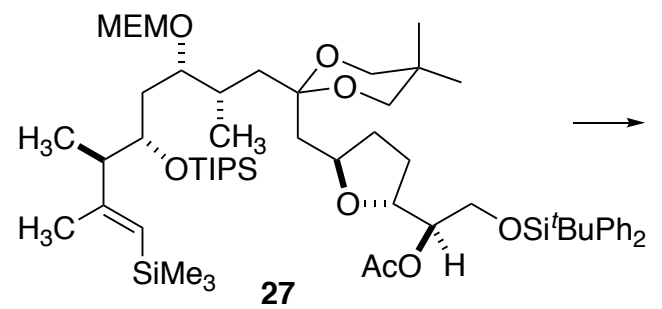

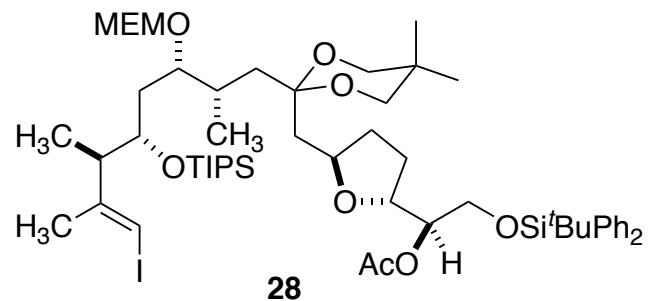


<smiles>C[C@@H](CC[C@H](O)CCO[R5](=O)[O-])C1SCCS1</smiles>

$$
\underset{\mathrm{CH}_{2} \mathrm{Cl}_{2}, 0^{\circ} \mathrm{C} \text { to r.t. }}{\stackrel{\text { MEMCl, }}{{ }^{2} \mathrm{Pr}_{2} \mathrm{NEt}}}
$$

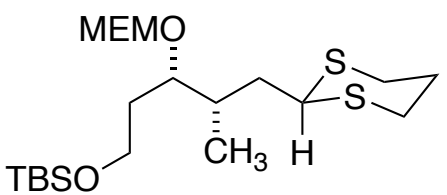

21

\section{$(S)-8-((R)-1-(1,3-D i t h i a n-2-y l) p r o p a n-2-y l)-12,12,13,13-t e t r a m e t h y l-2,5,7,11-t e t r a 0 x a-12-$}

\section{silatetradecane 21 .}

The dithiane 21 was prepared via the synthesis of Scheme 1 using the Brown asymmetric crotylation as previously described. In the case of 3-dimethyl-tert-butylsiloxy-propanal, this reaction has been published in the literature. ${ }^{3}$

A solution of the starting alcohol $(1.0 \mathrm{~g}, 4.10 \mathrm{mmol})$ in dimethylformamide $(5 \mathrm{~mL})$ was cooled to $0{ }^{\circ} \mathrm{C}$. To this, diisopropylamine $(1.43 \mathrm{~mL}, 8.20 \mathrm{mmol})$ was added, followed by $\operatorname{MEMCl}(0.52 \mathrm{~mL}, 4.51 \mathrm{mmol})$. The reaction mixture was warmed to room temperature, transferred to an oil bath and heated at $60{ }^{\circ} \mathrm{C}$ with stirring overnight. After cooling the flask, the reaction mixture was diluted with dithyl ether. The organic layer was separated and the aqueous layer was extracted with diethyl ether. The combined organic fractions were washed with brine (100 mL x 10), dried over anhydrous magnesium sulfate, filtered, and concentrated in vacuo. Flash chromatography (silica gel) of the crude product (20\% EtOAc/Hexanes) provided the desired MEM ether 21 as a clear oil. Yield $=1.67 \mathrm{~g}(93 \%): \mathrm{R}_{f}=0.5(25 \%$ ethyl acetate in hexanes); ${ }^{1} \mathrm{H}$ NMR (400 MHz, $\left.\mathrm{CDCl}_{3}\right) \delta 4.74(\mathrm{~s}, 2 \mathrm{H}), 4.13-4.09(\mathrm{~m}, 1 \mathrm{H}), 3.91-3.86(\mathrm{~m}, 1 \mathrm{H})$, $3.81-3.73(\mathrm{~m}, 2 \mathrm{H}), 3.22(\mathrm{~s}, 1 \mathrm{H}), 2.91-2.78(\mathrm{~m}, 4 \mathrm{H}), 2.11-2.08(\mathrm{~m}, 1 \mathrm{H}), 1.94-1.80(\mathrm{~m}, 3 \mathrm{H})$, $1.73-1.51(\mathrm{~m}, 3 \mathrm{H}), 0.92(\mathrm{~d}, J=6.4 \mathrm{~Hz}, 3 \mathrm{H}), 0.88(\mathrm{~s}, 9 \mathrm{H}), 0.06(\mathrm{~s}, 6 \mathrm{H}), 0.03(\mathrm{~s}, 6 \mathrm{H}) ;{ }^{13} \mathrm{C} \mathrm{NMR}$ $\left(100 \mathrm{MHz} \mathrm{CDCl}_{3}\right) \delta 94.9,77.5,71.6,67.0,59.7,58.8,45.3,37.5,33.8,32.5,30.2,30.0,26.0$, 25.8, 18.0, 14.6, -5.47, -5.53; IR (NaCl plate) 2957, 1467, 1421, 1384, 1363, 1276, 1253, 1173,

3. Kim, Y.-J.; Wang, P.; Navarro-Villalobos, M.; Rohde, B. D.; Derryberry, J.; Gin, D. Y. J. Am. Chem. Soc. 2006, $128,11906-11915$. 
1094, 1045, 939, 913, 834, 777, 723, $665 \mathrm{~cm}^{-1}$; HRMS (CI) $m / z:[\mathrm{M}+\mathrm{Na}]^{+}$Calcd for

$\mathrm{C}_{20} \mathrm{H}_{42} \mathrm{O}_{4} \mathrm{NaSiS}_{2}$ 461.2192; Found 461.2230.

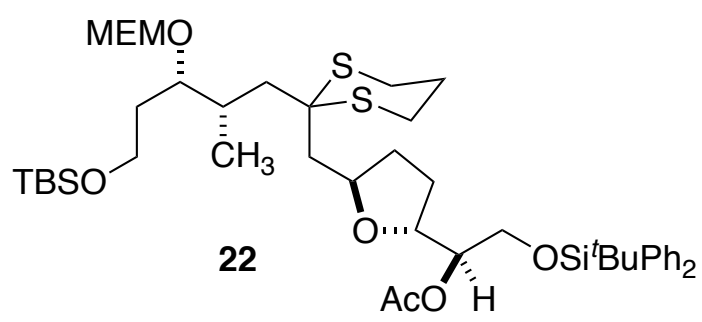

(R)-1-((2R,5R)-5-((2-((2S,3S)-5-(Tert-butyldimethylsilyloxy)-3-((2-

methoxyethoxy)methoxy)-2-methylpentyl-1,3-dithian-2-yl)methyl)tetrahydrofuran-2-yl)-2(tert-butyldiphenylsilyloxy)ethanol (22).

Dithiane 21 (3.50 g, $7.98 \mathrm{mmol})$ was dissolved in THF $(20.0 \mathrm{~mL})$ and cooled to $-45^{\circ} \mathrm{C}$. $n-\mathrm{BuLi}$ ( $3.5 \mathrm{~mL}, 2.50 \mathrm{M}$ in hexanes, $8.78 \mathrm{mmol}$ ) was added followed by addition of $n-\mathrm{Bu}_{2} \mathrm{Mg}$ (2.2 $\mathrm{mL}, 1 \mathrm{M}$ in heptanes, $2.2 \mathrm{mmol}$ ). The reaction mixture was allowed to come to room temperature for over $1 \mathrm{~h}$. The reaction was cooled to $0{ }^{\circ} \mathrm{C}$ and a solution of bis-epoxide 19 (2.80 $\mathrm{g}, 7.3 \mathrm{mmol})$ in THF $(10.0 \mathrm{~mL})$ was added for 5 minutes. The reaction was stirred for $1 \mathrm{~h}$ at that temperature and the allowed to come to room temperature and stirred for another $3 \mathrm{~h}$. DMAP and Acetyl chloride was added to the reaction mixture and stirred for another $2 \mathrm{~h}$ at room temperature. The reaction mixture was diluted with hexanes and quenched by slow addition of saturated sodium bicarbonate solution $(10 \mathrm{~mL})$. The organic layer was separated and the aqueous layer was washed with diethyl ether $(3 \times 25 \mathrm{~mL})$. The combined organic layers were dried over anhydrous magnesium sulfate, filtered, and concentrated in vacuo. Flash chromatography (silica gel) of the crude product ( $15 \%$ ethyl acetate/hexanes) provided the acetate 22 as a colorless oil. Yield $=4.63$ $\mathrm{g}(76 \%) .[\alpha]_{\mathrm{D}}^{25}+21.7\left(c\right.$ 1.45, $\left.\mathrm{CHCl}_{3}\right) ;{ }^{1} \mathrm{H} \mathrm{NMR}\left(400 \mathrm{MHz}, \mathrm{CDCl}_{3}\right) \delta 7.67-7.64(\mathrm{~m}, 4 \mathrm{H}), 7.44-$ $7.35(\mathrm{~m}, 6 \mathrm{H}), 4.95$ (app. q, $J=5.4 \mathrm{~Hz}, 1 \mathrm{H}), 4.81(\mathrm{~d}, J=7.2 \mathrm{~Hz}, 1 \mathrm{H}), 4.70(\mathrm{~d}, J=6.8 \mathrm{~Hz}, 1 \mathrm{H}), 4.22$ (app. q, $J=5.1 \mathrm{~Hz}, 1 \mathrm{H}), 4.18-4.12(\mathrm{~m}, 1 \mathrm{H}), 3.78(\mathrm{~d}, J=4.8 \mathrm{~Hz}, 2 \mathrm{H}), 3.75-3.61(\mathrm{~m}, 4 \mathrm{H}), 3.55(\mathrm{t}$, 
$J=5.2 \mathrm{~Hz}, 2 \mathrm{H}), 3.38(\mathrm{~s}, 3 \mathrm{H}), 2.86-2.70(\mathrm{~m}, 4 \mathrm{H}), 2.35(\mathrm{dd}, J=14.8,2.4 \mathrm{~Hz}, 1 \mathrm{H}), 2.25(\mathrm{dd}, J=$ 14.8, 4.8 Hz, 1H), 2.20-2.13 (m, 1H), 2.07-1.97 (m, 6H), 1.90 (app. t, $J=5.4 \mathrm{~Hz}, 2 \mathrm{H}), 1.68-1.51$ $(\mathrm{m}, 7 \mathrm{H}), 1.03(\mathrm{~s}, 3 \mathrm{H}), 1.00(\mathrm{~d}, J=7.2 \mathrm{~Hz}, 3 \mathrm{H}), 0.88(\mathrm{~s}, 9 \mathrm{H}) ;{ }^{13} \mathrm{C} \mathrm{NMR}\left(100 \mathrm{MHz}, \mathrm{CDCl}_{3}\right) \delta 170.6$, $135.6,135.5,133.3,129.7,127.68,127.65,94.5,79.1,76.2,76.0,75.9,71.8,67.2,63.2,60.3,59.0$, $45.0,41.1,34.3,34.1,32.2,28.3,26.7,26.2,26.1,25.9,25.0,21.2,19.2,18.2,17.6,-5.27,-5.33$; IR ( $\mathrm{NaCl}$ plate) 3068, 3044, 2958, 2931, 2889, 2860, 1742, 1467, 1427, 1368, 1238, 1107, 1039, 834, 777, 742, $704 \mathrm{~cm}^{-1}$; HRMS (CI) $m / z$ : $[\mathrm{M}+\mathrm{Na}]^{+}$Calcd for $\mathrm{C}_{45} \mathrm{H}_{74} \mathrm{O}_{8} \mathrm{NaSi}_{2} \mathrm{~S}_{2}$ 885.4261; Found 885.4222 .

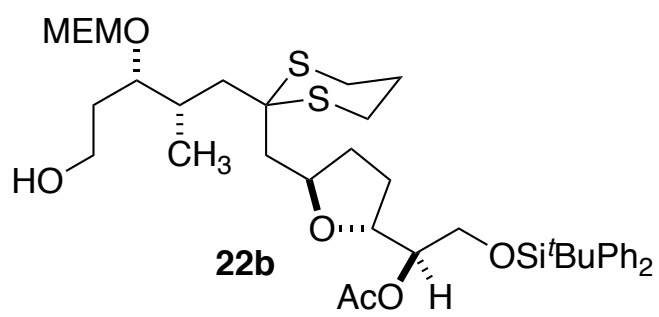

(R)-2-(Tert-butyldiphenylsilyloxy)-1-((2R,5R)-5-((2-((2S,3S)-5-hydroxy-3-((2methoxyethoxy)methoxy)-2-methylpentyl-5,5-dimethyl-1,3-dioxan-2yl)methyl)tetrahydrofuran-2-yl)ethyl acetate (22b).

Silyl ether 22 (1.2 g, $1.39 \mathrm{mmol})$ was dissolved in methanol (12 mL) and PPTS (209.0 mg, $0.348 \mathrm{mmol}$ ) was added in one portion. The reaction was stirred for $5 \mathrm{~h}$ at $40{ }^{\circ} \mathrm{C}$, brought to room temperature, diluted with diethyl ether and then quenched with aqueous saturated sodium bicarbonate solution. The organic layer was separated and the aqueous layer was extracted with diethyl ether $(3 \times 50 \mathrm{~mL})$. The combined organic layers were dried over sodium sulfate, filtered and concentrated in vacuo. Flash chromatography (silica gel, 25\% ethyl acetate/hexanes) of the crude product provided the intermediate alcohol $\mathbf{2 2 b}$ as a colorless oil. Yield $=960 \mathrm{mg}(87 \%)$ : $\mathrm{R}_{f}$ $=0.20(50 \%$ ethyl acetate in hexanes $) ;[\alpha]_{\mathrm{D}}^{25}-18.8\left(c\right.$ 0.24, $\left.\mathrm{CHCl}_{3}\right) ;{ }^{1} \mathrm{H} \mathrm{NMR}\left(400 \mathrm{MHz}, \mathrm{CDCl}_{3}\right)$ 
$\delta$ 7.67-7.63 (m, 4H), 7.44-7.36 (m, 6H), $4.96(\mathrm{dd}, J=10.8,5.2 \mathrm{~Hz}, 1 \mathrm{H}), 4.88(\mathrm{~d}, J=7.2 \mathrm{~Hz}, 1 \mathrm{H})$, $4.64(\mathrm{~d}, J=6.8 \mathrm{~Hz}, 1 \mathrm{H}), 4.22$ (app. q, $J=6.4 \mathrm{~Hz}, 1 \mathrm{H}), 4.17-4.11(\mathrm{~m}, 1 \mathrm{H}), 3.89-3.85(\mathrm{~m}, 1 \mathrm{H})$, 3.80-3.73 ( m, 4H), 3.69-3.64 (m, 1H), 3.62-3.52 (m, 3H), $3.39(\mathrm{~s}, 3 \mathrm{H}), 2.87(\mathrm{t}, J=6.2 \mathrm{~Hz}, 1 \mathrm{H})$, $2.78(\mathrm{t}, J=5.4 \mathrm{~Hz}, 4 \mathrm{H}), 2.31(\mathrm{~d}, J=14.8 \mathrm{~Hz}, 2 \mathrm{H}), 2.25-1.96(\mathrm{~m}, 6 \mathrm{H}), 1.90$ (app. q, $J=5.4 \mathrm{~Hz}$ 2H), $1.72-1.49(\mathrm{~m}, 4 \mathrm{H}), 1.03(\mathrm{~s}, 9 \mathrm{H}), 1.00(\mathrm{~d}, J=7.2 \mathrm{~Hz}, 3 \mathrm{H}) ;{ }^{13} \mathrm{C} \mathrm{NMR}\left(100 \mathrm{MHz}, \mathrm{CDCl}_{3}\right) \delta$ $170.6,135.6,135.5,133.3,133.2,129.69,127.68,127.65,93.8,78.5,76.3,76.1,75.9,71.8,67.3$, $63.2,59.3,59.0,53.2,45.1,40.3,34.1,32.3,31.3,28.2,26.7,26.2,26.1,25.0,21.2,19.2,18.4$; IR ( $\mathrm{NaCl}$ plate) 3475 (br), 3065, 2937, 2887, 1739, 1452, 1430, 1373, 1240, 1105, 1040, 817, 743, $703 \mathrm{~cm}^{-1}$; HRMS (CI) m/z: [M+Na] ${ }^{+}$Calcd for $\mathrm{C}_{39} \mathrm{H}_{60} \mathrm{O}_{8} \mathrm{NaSiS}_{2}$ 771.3397; Found 771.3417.

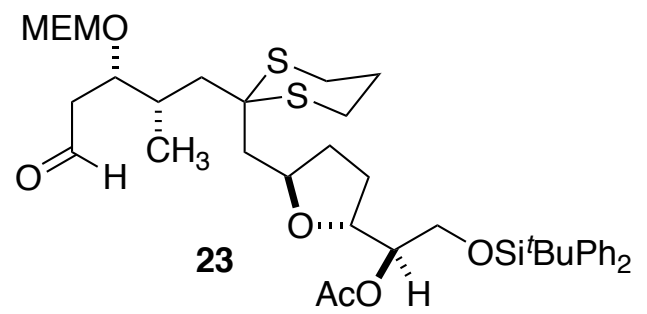

(R)-2-(Tert-butyldiphenylsilyloxy)-1-((2R,5R)-5-((2-((2S,3S)-3-((2-methoxyethoxy)methoxy)2-methyl-5-oxopentyl)-1,3-dithian-2-yl)methyl)tetrahydrofuran-2-yl)ethyl acetate (23).

A solution of alcohol 22b (1.86 g, $2.49 \mathrm{mmol})$ in dichloromethane $(50 \mathrm{~mL})$ was cooled to $0{ }^{\circ} \mathrm{C}$. To this diisoproylethylamine $(2.16 \mathrm{~mL}, 12.45 \mathrm{mmol})$ and dimethyl sulfoxide $(1.77 \mathrm{~mL}, 24.9$ mmol) were added. Then, $\mathrm{SO}_{3} \cdot \mathrm{Pyr}(990 \mathrm{mg}, 6.21 \mathrm{mmol})$ was added in one portion. The reaction was warmed to room temperature and stirred three hours. The reaction mixture was diluted with dichloromethane and quenched with sodium bicarbonate solution. The organic layer was separated and the aqueous layer was extracted with dichloromethane $(3 \times 100 \mathrm{~mL})$. The combined organic layers were dried over anhydrous magnesium sulfate, filtered and concentrated in vacuo. Flash chromatography (silica gel) of the crude product using $20 \%$ ethyl acetate/hexanes mixture provided aldehyde 23 as a light yellow oil. Yield $=1.58 \mathrm{~g}(85 \%): \mathrm{R}_{f}=0.6(50 \%$ ethyl acetate in 
hexanes); $[\alpha]_{\mathrm{D}}^{25}-22.1\left(\mathrm{c} 1.12, \mathrm{CHCl}_{3}\right) ;{ }^{1} \mathrm{H} \mathrm{NMR}\left(400 \mathrm{MHz}, \mathrm{CDCl}_{3}\right) \delta 9.73(\mathrm{dd}, J=3.1,1.6 \mathrm{~Hz}$ 1H), 7.63 (ddd, $J=7.9,4.9,1.6 \mathrm{~Hz}, 4 \mathrm{H}), 7.37$ (dddd, $J=13.9,8.3,4.2,1.7 \mathrm{~Hz}, 6 \mathrm{H}), 4.94(\mathrm{q}, J=$ $5.3 \mathrm{~Hz}, 1 \mathrm{H}), 4.83(\mathrm{~d}, J=7.3 \mathrm{~Hz}, 1 \mathrm{H}), 4.65(\mathrm{~d}, J=7.3 \mathrm{~Hz}, 1 \mathrm{H}), 4.27-4.03(\mathrm{~m}, 3 \mathrm{H}), 3.75(\mathrm{~d}, J=5.1$ $\mathrm{Hz}, 2 \mathrm{H}), 3.69$ (dt, $J=10.4,4.3 \mathrm{~Hz}, 1 \mathrm{H}), 3.61-3.52(\mathrm{~m}, 1 \mathrm{H}), 3.51$ (dd, $J=5.1,3.8 \mathrm{~Hz}, 2 \mathrm{H}), 3.35$ (s, 3H), $2.76(\mathrm{dt}, J=7.0,4.2 \mathrm{~Hz}, 4 \mathrm{H}), 2.58(\mathrm{ddd}, J=16.2,8.7,3.1 \mathrm{~Hz}, 1 \mathrm{H}), 2.44-2.22(\mathrm{~m}, 2 \mathrm{H})$, 2.22-2.06 (m, 4H), $2.04(\mathrm{~s}, 3 \mathrm{H}), 2.01-1.79(\mathrm{~m}, 2 \mathrm{H}), 1.69-1.43(\mathrm{~m}, 4 \mathrm{H}), 1.01(\mathrm{~s}, 9 \mathrm{H}), 0.98(\mathrm{~d}, J=$ $6.9 \mathrm{~Hz}, 3 \mathrm{H}) ;{ }^{13} \mathrm{C} \mathrm{NMR}\left(100 \mathrm{MHz}, \mathrm{CDCl}_{3}\right) \delta 201.6,170.5,135.6,135.5,133.3,133.2,129.7$, $127.68,127.66,76.6,76.4,76.0,75.8,71.7,67.3,63.2,59.0,52.9,45.6,45.0,40.9,34.0,32.6$, 28.1, 26.7, 26.2, 26.1, 24.9, 21.1, 19.2, 17.7; IR (NaCl plate) 3060, 2933, 2889, 1736, 1468, 1427 , 1369, 1238, 1109, 1037, 822, 742, $704 \mathrm{~cm}^{-1}$; HRMS (CI) $m / z:[\mathrm{M}+\mathrm{Na}]^{+}$Calcd for $\mathrm{C}_{39} \mathrm{H}_{58} \mathrm{O}_{8} \mathrm{NaS}_{2} \mathrm{Si}$ 769.3240; Found 769.3275.
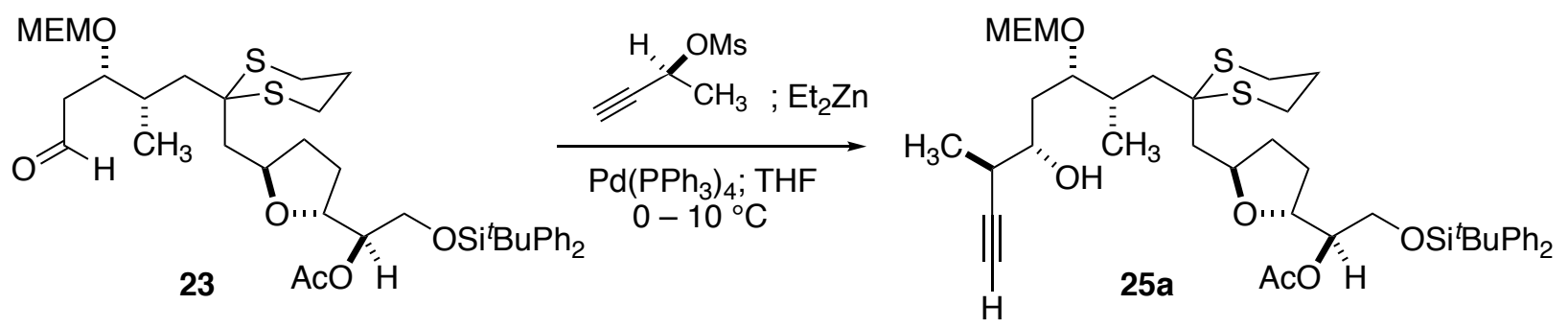

(R)-2-(Tert-butyldiphenylsilyloxy)-1-((2R,5R)-5-((2-((2S,3S,5S,6R)-5-hydroxy-3-((2methoxyethoxy)methoxy)-2,6-dimethyloct-7-ynyl)-1,3-dithian-2-yl)methyl)tetrahydrofuran2-yl)ethyl acetate (25a).

Propargyl mesylate $24(149 \mathrm{mg}, 1.01 \mathrm{mmol})$ was added to a THF $(5.0 \mathrm{~mL})$ solution of aldehyde 23 (340 mg, $0.455 \mathrm{mmol}$ ). The solution was cooled to $0{ }^{\circ} \mathrm{C}$ prior to single portion addition of $\mathrm{Pd}\left(\mathrm{PPh}_{3}\right)_{4}(37 \mathrm{mg}, 0.032 \mathrm{mmol})$. Addition of $\mathrm{Et}_{2} \mathrm{Zn}$ as a $1.0 \mathrm{M}$ in hexanes solution $(1.35 \mathrm{~mL}, 1.35 \mathrm{mmol})$ immediately followed. The reaction vessel was then transferred to an ice bath at $7{ }^{\circ} \mathrm{C}$. The reaction was stirred between $7{ }^{\circ} \mathrm{C}$ and $12{ }^{\circ} \mathrm{C}$ for 5 hours before removal of the 
ice bath. The solution was stirred 15 minutes at room temperature prior to cooling to $10{ }^{\circ} \mathrm{C}$ and dilution with hexanes. The reaction was then quenched with aqueous $\mathrm{NH}_{4} \mathrm{Cl}$. The product was extracted via repeated diethyl ether extractions and dried over anhydrous $\mathrm{Na}_{2} \mathrm{SO}_{4}$. Column chromatography (silica gel, gradient of $10-40 \%$ ethyl acetate/hexanes) yielded the intermediate alcohol 25a as a light yellow oil (241 mg, 66\% yield). $\mathrm{R}_{f}=0.5$ (ethyl acetate/hexanes $\left.1: 1\right) ;[\alpha]_{\mathrm{D}}^{25}$ $-36.3\left(c=1.0, \mathrm{CH}_{2} \mathrm{Cl}_{2}\right) ;{ }^{1} \mathrm{H} \mathrm{NMR}\left(400 \mathrm{MHz}, \mathrm{CDCl}_{3}\right) \delta 1.02(\mathrm{~s}, 12 \mathrm{H}), 1.24(\mathrm{~d}, J=2.8 \mathrm{~Hz}, 3 \mathrm{H})$, 1.45-1.77 (m, 6H), 1.85-1.95 (m, 2H), 1.95-2.05 (m, 2H), $2.05(\mathrm{~s}, 3 \mathrm{H}), 2.08(\mathrm{~d}, J=2.8 \mathrm{~Hz}, 1 \mathrm{H})$, 2.13-2.15 (m, 2H), $2.25(\mathrm{dd}, J=14.8,4.8 \mathrm{~Hz}, 1 \mathrm{H}), 2.31$ (app. d, $J=13.6,1 \mathrm{H}), 2.47-2.54(\mathrm{~m}, 1 \mathrm{H})$, 2.70-2.84 (m, 4H), $3.39(\mathrm{~s}, 4 \mathrm{H}), 3.50-3.63(\mathrm{~m}, 3 \mathrm{H}), 3.68-3.76(\mathrm{~m}, 1 \mathrm{H}), 3.77$ (app. d, $J=5.2 \mathrm{~Hz}$ 2H), 3.83-3.91 (m, 1H), 4.08-4.18 (m, 1H), 4.18-4.26 (m, 1H), $4.62(\mathrm{~d}, J=7.0 \mathrm{~Hz}, 1 \mathrm{H}), 4.86(\mathrm{~d}$, $J=7.0 \mathrm{~Hz}, 1 \mathrm{H}), 4.95$ (app. q, $J=5.2 \mathrm{~Hz}, 1 \mathrm{H}), 7.34-7.42(\mathrm{~m}, 6 \mathrm{H}), 7.63-7.67(\mathrm{~m}, 4 \mathrm{H}) ;{ }^{13} \mathrm{C} \mathrm{NMR}$ $\left(100 \mathrm{MHz}_{\mathrm{CDCl}}\right): 170.5,135.6,135.5,133.3,133.2,129.7,129.6,127.64,127.62,93.8,85.9$, $78.2,71.8,70.2,69.2,67.3,63.1,59.0,53.1,59.0,53.1,45.0,40.2,34.9,34.0,32.9,31.7,28.3$, 26.7, 26.2, 26.0, 24.9, 24.1, 19.2, 18.6, 17.; IR (NaCl plate) 3473, 3303, 3070, 2932, 2359, 1737 , 1589, 1428, 1368, 1239, 1033, 848, 823, 823, 739, $703 \mathrm{~cm}^{-1}$; HRMS (ESI) m/z: [M+Na $]^{+}$Calcd for $\mathrm{C}_{43} \mathrm{H}_{64} \mathrm{O}_{8} \mathrm{~S}_{2} \mathrm{SiNa} 823.3710$; Found 823.3729.
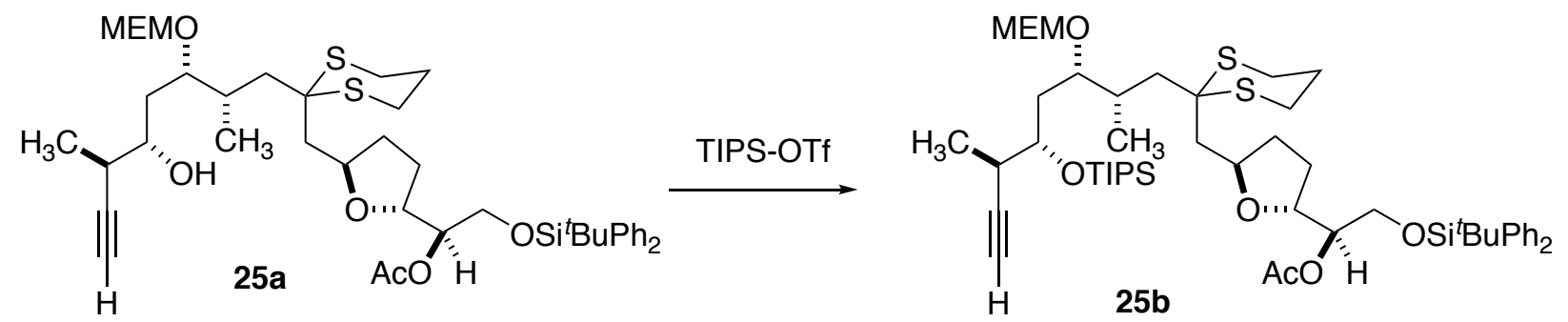

(R)-2-(Tert-butyldiphenylsilyloxy)-1-((2R,5R)-5-((2-((2S,3S,5S,6R)-3-((2-

methoxyethoxy)methoxy)-2,6-dimethyl-5-(triisopropylsilyloxy)-oct-7-ynyl)-1,3-dithian-2yl)methyl)tetrahydrofuran-2-yl)ethyl acetate (25b). 
The product of the previous experiment is identified as the homopropargyl alcohol 25a (1.25 g, $1.57 \mathrm{mmol})$, and was dissolved in dichloromethane $(3.0 \mathrm{~mL})$ and Hunig's base $(1.5 \mathrm{~mL}$, $8.6 \mathrm{mmol})$. TIPS-OTf $(0.51 \mathrm{~mL}, 1.89 \mathrm{mmol})$ was added dropwise over 2 minutes at room temperature. The solution was stirred 3.5 hours prior to dilution with hexanes and aqueous (saturated) sodium bicarbonate. After vigorous stirring, the organic layer was collected and repeated diethyl ether extraction of the aqueous layer was performed. The combined organics were dried over sodium sulfate and concentrated. Column chromatography (silica gel, gradient of 10\%-30\% EtOAc/hexanes) provided the desired silyl ether product $\mathbf{2 5} \mathbf{b}$ as a light yellow oil, which formed a white foam upon exposure to high vacuum $\left(1.065 \mathrm{~g}, 71 \%\right.$ yield). $\mathrm{R}_{f}=0.3$ (ethyl acetate/hexanes 1:3); $[\alpha]_{\mathrm{D}}^{25}-3.7\left(c=1.0, \mathrm{CH}_{2} \mathrm{Cl}_{2}\right) ;{ }^{1} \mathrm{H} \mathrm{NMR}\left(400 \mathrm{MHz}, \mathrm{CDCl}_{3}\right) \delta 7.69-7.63(\mathrm{~m}$, 4H), 7.45-7.34 (m, 6H), 4.95 (app. q, $J=5.2 \mathrm{~Hz}, 1 \mathrm{H}), 4.77(\mathrm{~s}, 2 \mathrm{H}), 4.23(\mathrm{dd}, J=12.8,6.8 \mathrm{~Hz}$, 1H), 4.19-4.10 (m, 1H), 3.98-3.91(m, 1H), 3.79 (app. d, J=4.8 Hz, 2H), 3.77-3.67 (m, 2H), 3.67$3.62(\mathrm{~m}, 1 \mathrm{H}), 3.55$ (app. t, $J=5.2 \mathrm{~Hz}, 2 \mathrm{H}), 3.37(\mathrm{~s}, 3 \mathrm{H}), 2.85-2.72(\mathrm{~m}, 5 \mathrm{H}), 2.34-2.23(\mathrm{~m}, 2 \mathrm{H})$, $2.22-2.14(\mathrm{~m}, 1 \mathrm{H}), 2.08-1.85(\mathrm{~m}, 10 \mathrm{H}), 1.70-1.50(\mathrm{~m}, 4 \mathrm{H}), 1.20(\mathrm{~d}, J=6.8 \mathrm{~Hz}, 3 \mathrm{H}), 1.08(\mathrm{~s}, 21 \mathrm{H})$, 1.04-1.00 (m, 12H), ${ }^{13} \mathrm{C}$ NMR $\left(100 \mathrm{MHz}, \mathrm{CDCl}_{3}\right) \delta 170.5,135.6,135.5,133.31,133.25,129.67$, $129.66,127.67,127.64,94.7,85.7,80.1,76.2,76.0,75.8,72.4,71.8,69.9,67.4,63.2,59.0,53.0$, $45.2,41.8,36.5,34.1,32.6,32.2,28.3,26.7,26.3,26.2,25.0,21.1,19.2,16.9,16.0,13.0 ; \mathrm{IR}(\mathrm{NaCl}$ plate) $3308,2932,2865,1743,1459,1428,1370,1237,1113,1040,824,741,703,680,613 \mathrm{~cm}^{-}$ 1; HRMS (ESI) $m / z$ : [M+Na] $]^{+}$Calcd for $\mathrm{C}_{52} \mathrm{H}_{84} \mathrm{O}_{8} \mathrm{~S}_{2} \mathrm{Si}_{2} \mathrm{Na} 979.5044$; Found 979.5073. 


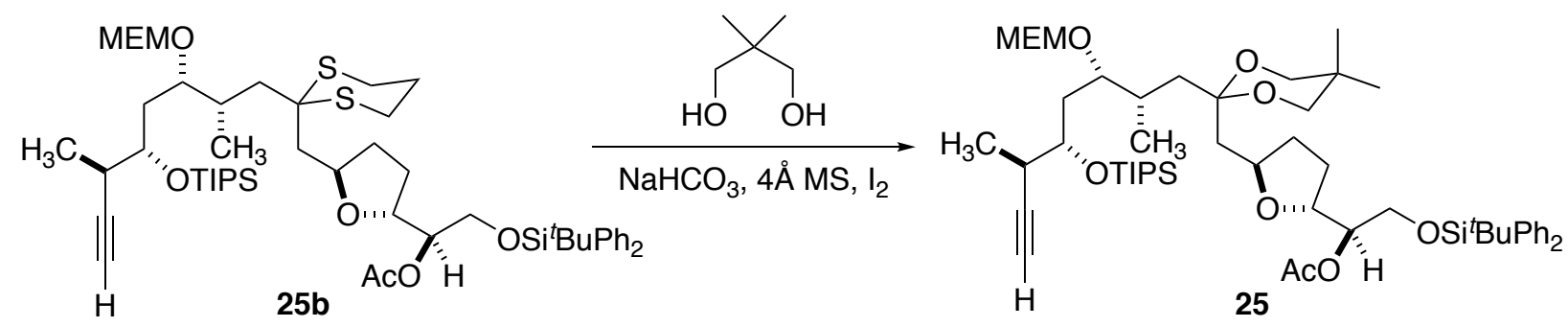

(R)-2-(Tert-butyldiphenylsilyloxy)-1-((2R,5R)-5-((2-((2S,3S,5S,6R)-3-((2-

methoxyethoxy)methoxy)-2,6-dimethyl-5-(triisopropylsilyloxy)oct-7-ynyl)-5,5-dimethyl-

1,3,dioxan-2-yl)methyl)tetrahydrofuran-2-yl)ethyl acetate (25).

To a suspension of flame-dried powdered molecular sieves ( $4 \AA$ ) and sodium bicarbonate (3.28 g, $39.04 \mathrm{mmol})$ in dichloromethane $(20 \mathrm{~mL})$, dithiane $25 \mathbf{b}(1.2 \mathrm{~g}, 1.17 \mathrm{mmol})$ and 2,2dimethyl-1,3-propanediol $(4.26 \mathrm{~g}, 40.96 \mathrm{mmol})$ were added at room temperature. The reaction mixture was further diluted with dichloromethane $(10 \mathrm{~mL})$ and was stirred at room temperature for 15 minutes prior to cooling to $0^{\circ} \mathrm{C}$. $\mathrm{I}_{2}$ was quickly added in one portion to the cold reaction mixture. After stirring 35 minutes, a saturated aqueous solution of sodium thiosulfate was added to the cold reaction mixture with vigorous stirring. The reaction mixture was diluted with hexanes and quenched with saturated aqueous solution of sodium bicarbonate. The organic layer was separated and the aqueous layer was extracted with diethyl ether $(3 \times 100 \mathrm{~mL})$. The combined organic layers were dried over anhydrous magnesium sulfate, filtered and concentrated in vacuo. Flash chromatography (silica gel) of the crude product using 10\% ethyl acetate/hexanes mixture provided the alkyne 25 as a colorless oil. Yield $=1.58 \mathrm{~g},(95 \%) . \mathrm{R}_{f}=0.3$ (ethyl acetate/hexanes $1: 3) ;[\alpha]_{\mathrm{D}}^{25}-5.0(c=1.0, \mathrm{DCM}) ;{ }^{1} \mathrm{H} \mathrm{NMR}\left(400 \mathrm{MHz}, \mathrm{C}_{6} \mathrm{D}_{6}\right) \delta 7.83-7.80(\mathrm{~m}, 2 \mathrm{H}), 7.80-7.75(\mathrm{~m}$ 2H), 7.25-7.21 (m, 6H), $5.22(\mathrm{dd}, J=10.2,5.8 \mathrm{~Hz}, 1 \mathrm{H}), 4.93(\mathrm{~d}, J=6.8 \mathrm{~Hz}, 1 \mathrm{H}), 4.88(\mathrm{~d}, J=6.8$ $\mathrm{Hz}, 1 \mathrm{H}), 4.31-4.22(\mathrm{~m}, 2 \mathrm{H}), 4.18(\mathrm{dd}, J=12.4,6.8 \mathrm{~Hz}, 1 \mathrm{H}), 3.95-3.86(\mathrm{~m}, 3 \mathrm{H}), 3.78$ (app. t, $J=$ $5.2 \mathrm{~Hz}, 2 \mathrm{H}), 3.46-3.29(\mathrm{~m}, 6 \mathrm{H}), 3.14(\mathrm{~s}, 3 \mathrm{H}), 2.96-2.88(\mathrm{~m}, 1 \mathrm{H}), 2.39-2.23(\mathrm{~m}, 4 \mathrm{H}), 2.01-1.90$ 
$(\mathrm{m}, 3 \mathrm{H}), 1.90(\mathrm{~d}, J=2.8 \mathrm{~Hz}, 1 \mathrm{H}), 1.86(\mathrm{~s}, 3 \mathrm{H}), 1.80(\mathrm{dd}, J=14.4,7.2 \mathrm{~Hz}, 1 \mathrm{H}), 1.73-1.63(\mathrm{~m}, 1 \mathrm{H})$, $1.47-1.37(\mathrm{~m}, 2 \mathrm{H}), 1.33(\mathrm{~d}, J=7.2 \mathrm{~Hz}, 3 \mathrm{H}), 1.28$ (d, $J=6.8 \mathrm{~Hz}, 3 \mathrm{H}), 1.18-1.11(\mathrm{~m}, 30 \mathrm{H}), 0.87$ (s, 3H), 0.63 (s, 3H); ${ }^{13} \mathrm{C}$ NMR (100 MHz, C6 $\left.\mathrm{D}_{6}\right)$ 169.9, 136.0, 135.9, 133.81, 133.78, 130.04, 130.00, 128.11, 128.10, (127.99 benzene reference), 100.4, 95.5, 85.8, 80.3, 76.5, 76.1, 76.0, 73.1, $72.3,70.7,70.2,70.1,67.9,63.9,58.7,39.5,38.5,36.9,34.0,32.9,32.0,29.5,28.5,27.0,23.1$, 22.6, 20.9, 19.4, 18.5, 16.6, 15.9, 13.4; IR (NaCl plate) 2936, 1735, 1459, 1427, 1364, 1238, 1037 , 739, $702 \mathrm{~cm}^{-1}$; HRMS (ESI) m/z: [M+Na] ${ }^{+}$Calcd for $\mathrm{C}_{54} \mathrm{H}_{88} \mathrm{O}_{10} \mathrm{Si}_{2} \mathrm{Na}$ 975.5814; Found 975.5818.
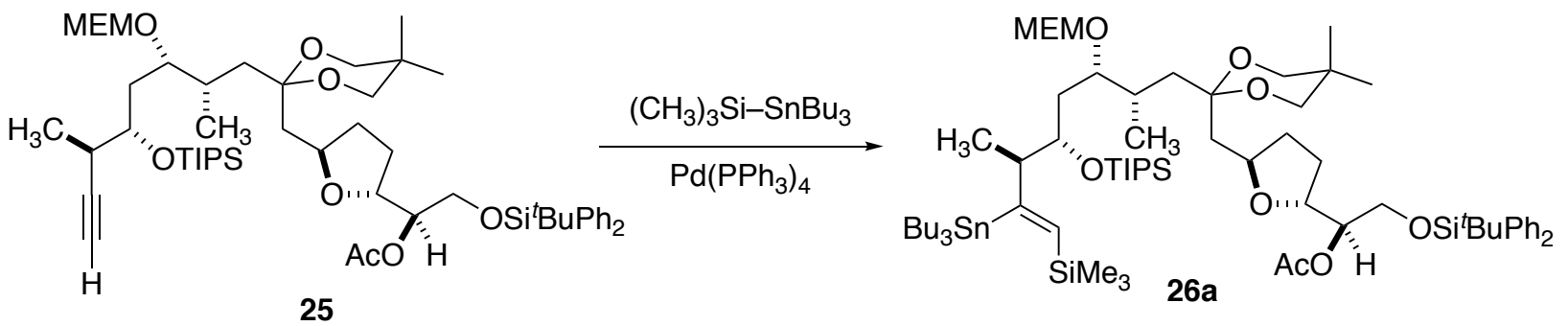

(R)-2-(Tert-butyldiphenylsilyloxy-1-((2R,5R)-5-((2-((2S,3S,5S,6S,Z)-3-((2-

methoxyethoxy)methoxy)-2,6-dimethyl-7-(tributylstannyl)-5-(triisopropylsilyloxy)-8(trimethylsilyl)oct-7-enyl)-5,5-dimethyl-1,3-dioxan-2-yl)methyl)tetrahydrofuran-2-yl)ethyl acetate (26a).

Alkyne 25 was concentrated from a benzene/triethylamine solution under reduced pressured immediately prior to use. The alkyne 25 (400 mg, $0.42 \mathrm{mmol})$ was dissolved in THF $(2.0 \mathrm{~mL})$ and $\left(\mathrm{CH}_{3}\right)_{3} \mathrm{Si}-\mathrm{SnBu}_{3}(0.10 \mathrm{~mL}, 0.283 \mathrm{mmol})$ was added as a neat solution under argon. $\mathrm{Pd}\left(\mathrm{PPh}_{3}\right)_{4}(30 \mathrm{mg}, 0.026 \mathrm{mmol})$ was added in one portion at room temperature and the reaction vessel was immediately transferred to a $45^{\circ} \mathrm{C}$ oil bath. The reaction was monitored hourly by TLC. Periodically, additional $\mathrm{Pd}\left(\mathrm{PPh}_{3}\right)_{4}(60 \mathrm{mg}, 0.052 \mathrm{mmol}$; in $20 \mathrm{mg}$ portions $)$ and $\left(\mathrm{CH}_{3}\right)_{3} \mathrm{Si}-$ $\mathrm{SnBu}_{3}(0.82,2.32 \mathrm{mmol}$; in $0.1 \mathrm{~mL}$ portions $)$ were added to the vigorously stirred solution. Over the 12 hour reaction time, the solution turned from bright yellow to brown/black. After cooling to 
room temperature the solution was filtered through a plug of celite and concentrated for chromatography. Silica gel chromatography (5-15\% EtOAc/hexanes) gave the desired silyl stannane 26a as an oil (535 mg, 97\%). $\mathrm{R}_{f}=0.7$ (ethyl acetate/hexanes 1:3); $[\alpha]_{\mathrm{D}}^{25}-20.4(c=1.0$,$) ;$ ${ }^{1} \mathrm{H}$ NMR(400 MHz, $\left.\mathrm{CDCl}_{3}\right) \delta$ 7.69-7.64 (m, 4H), 7.49- $7.35(\mathrm{~m}, 6 \mathrm{H}), 6.60(\mathrm{~s}, 1 \mathrm{H})$ [117Sn and 119Sn observed], $4.97(\mathrm{dd}, J=10.6,5.0 \mathrm{~Hz}, 1 \mathrm{H}), 4.80(\mathrm{~d}, J=6.8 \mathrm{~Hz}, 1 \mathrm{H}), 4.74(\mathrm{~d}, J=6.8 \mathrm{~Hz}$, 1H), 4.27-4.19 (m, 2H), 4.19-4.10 (m, 1H), 3.80 (app. d, $J=5.2 \mathrm{~Hz}, 2 \mathrm{H}), 3.78-3.62$ (m, 3H), 3.60-3.40 (m, 6H), $3.38(\mathrm{~s}, 3 \mathrm{H}), 2.57(\mathrm{dd}, J=13.4,6.2 \mathrm{~Hz}, 1 \mathrm{H}), 2.18-2.10(\mathrm{~m}, 3 \mathrm{H}), 2.07(\mathrm{~s}, 3 \mathrm{H})$, 2.04-1.89 (m, 2H), $1.83(\mathrm{dd}, J=14.2,7.4 \mathrm{~Hz}, 1 \mathrm{H}), 1.68-1.42(\mathrm{~m}, 10 \mathrm{H}), 1.40-1.24(\mathrm{~m}, 6 \mathrm{H}), 1.07$ $(\mathrm{s}, 21 \mathrm{H}), 1.04(\mathrm{~s}, 9 \mathrm{H}), 1.02-0.88(\mathrm{~m}, 28 \mathrm{H}), 0.09(\mathrm{~s}, 9 \mathrm{H}) ;{ }^{13} \mathrm{C} \mathrm{NMR}\left(100 \mathrm{MHz}, \mathrm{CDCl}_{3}\right) \delta 170.6$ $168.1,141.9,135.6,135.5,133.4,133.3,129.7,127.7,127.6,99.8,95.3,81.5,76.2,76.1,75.8$, $72.8,71.8,70.0,69.9,67.6,63.3,59.0,50.5,40.1,35.3,34.8,33.5,31.2,29.6,29.2,28.5,27.6$, 26.7, 22.8, 21.2, 19.2, 18.4, 17.2, 15.0, 13.6, 13.1, 11.5, 0.3; IR (NaCl plate) 2955, 2867, 1745, 1463, 1427, 1367, 1238, 1112, 1041, 864, 834, $741 \mathrm{~cm}^{-1}$; HRMS (ESI) $m / z:[\mathrm{M}+\mathrm{Na}]^{+}$Calcd for $\mathrm{C}_{69} \mathrm{H}_{124} \mathrm{O}_{10} \mathrm{Si}_{3} \mathrm{SnNa} 1339.7422$, Found 1339.7416.
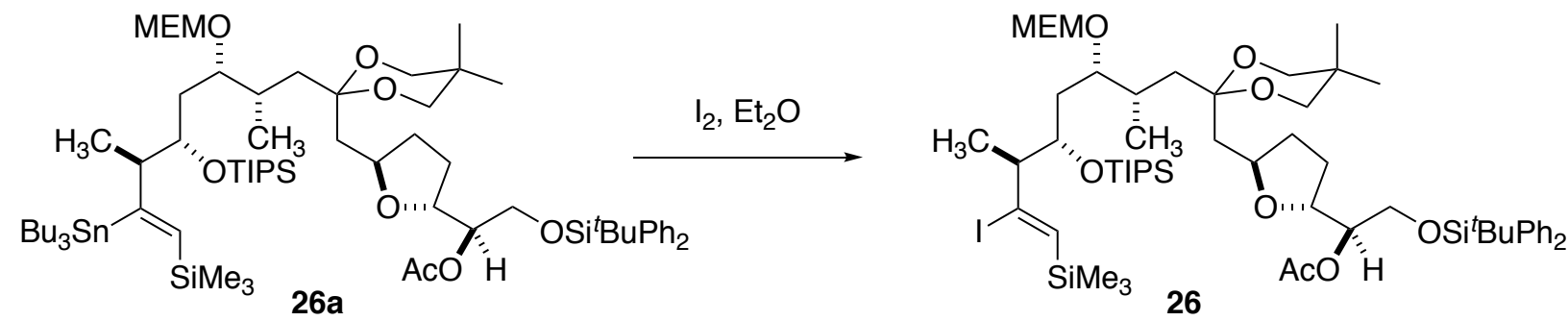

(R)-2-(Tert-butyldiphenylsilyloxy)-1-((2R,5R)-5-((2-((2S,3S,5S,6S,Z)-7-iodo-3-((2methoxyethoxy)methoxy)-2,6-dimethyl-5-(triisopropylsilyloxy)-8-(trimethylsilyl)oct-7enyl)-5,5-dimethyl-1,3-dioxan-2-yl)methyl)tetrahydrofuran-2-yl)ethyl acetate (26).

A diethyl ether $(10.0 \mathrm{~mL}$ ) solution of stannane 26a ( $530 \mathrm{mg}, 0.4025 \mathrm{mmol}$ ) was prepared at room temperature. 2,6-Lutidine $(0.075 \mathrm{~mL})$ was added and the solution was cooled to $0{ }^{\circ} \mathrm{C}$. 
Iodine (142 mg, $0.5595 \mathrm{mmol})$ was added in one portion with vigorous stirring. TLC indicated greater than $90 \%$ conversion after 15 minutes. After stirring 30 minutes, aqueous sodium thiosulfate (saturated solution) was added and the ice bath removed. Repeated diethyl ether extraction was performed and the combined organics were dried over anhydrous sodium sulfate. The crude reaction mixture was purified by gradient column chromatography (silica gel, 5\% EtOAc/hexanes) to remove residual 2,6-lutidine, then elution using 15\% EtOAc) to give the desired vinyl iodide 26 as an oil (436 mg, 94\%). $\mathrm{R}_{f}=0.6$ (ethyl acetate/hexanes $\left.1: 3\right) ;[\alpha]_{\mathrm{D}}^{25}-5.5(c$ $\left.=1.0, \mathrm{CH}_{2} \mathrm{Cl}_{2}\right) ;{ }^{1} \mathrm{H}$ NMR $\left(400 \mathrm{MHz}, \mathrm{CDCl}_{3}\right): \delta 7.70-7.64(\mathrm{~m}, 4 \mathrm{H}), 7.45-7.32(\mathrm{~m}, 6 \mathrm{H}), 6.63(\mathrm{~s}$, 1H), 4.97 (app. q, $J=5.2 \mathrm{~Hz}, 1 \mathrm{H}), 4.81(\mathrm{~d}, J=6.4 \mathrm{~Hz}, 1 \mathrm{H}), 4.77$ (d, $J=6.4 \mathrm{~Hz}, 1 \mathrm{H}), 4.30-4.20$ (m, 2H), 4.17-4.10 (m, 1H), 3.81 (app. d, $J=4.8 \mathrm{~Hz}, 2 \mathrm{H}), 3.80-3.71(\mathrm{~m}, 2 \mathrm{H}), 3.67-3.62(\mathrm{~m}, 1 \mathrm{H})$, 3.57-3.53 (m, 2H), 3.47 (s, 4H), $3.38(\mathrm{~s}, 3 \mathrm{H}), 2.84-2.76(\mathrm{~m}, 1 \mathrm{H}), 2.19-1.91(\mathrm{~m}, 8 \mathrm{H}), 1.84$ (dd, $J$ $=14.4,7.6 \mathrm{~Hz}, 1 \mathrm{H}), 1.69-1.40(\mathrm{~m}, 5 \mathrm{H}), 1.14(\mathrm{~d}, J=6.8,3 \mathrm{H}), 1.11(\mathrm{~s}, 21 \mathrm{H}), 1.05(\mathrm{~s}, 9 \mathrm{H}), 0.97(\mathrm{~d}$, $J=6.4 \mathrm{~Hz}, 3 \mathrm{H}), 0.95(\mathrm{~s}, 3 \mathrm{H}), 0.91(\mathrm{~s}, 3 \mathrm{H}), 0.20(\mathrm{~s}, 9 \mathrm{H}) ;{ }^{13} \mathrm{C} \mathrm{NMR}\left(100 \mathrm{MHz}, \mathrm{CDCl}_{3}\right)$ 170.6, 137.4, $135.6,135.5,133.2,129.6,127.64,127.61,125.1,99.7,95.2,80.4,76.2,76.1,75.7,72.0,71.8$ $70.0,67.5,63.3,59.0,57.0,39.8,36.2,34.1,33.5,31.2,29.5,28.4,26.7,22.9,22.7,21.1,19.2$, 18.39, 18.36, 16.6, 14.6, 13.0, -1.1; IR (film) $v_{\max }: 2955,1742,1589,1459,1427,1364,1238$, 1112, 845, 739, $702 \mathrm{~cm}^{-1}$; HRMS (ESI) $\mathrm{m} / z$ : $[\mathrm{M}+\mathrm{Na}]^{+}$Calcd for $\mathrm{C}_{57} \mathrm{H}_{97} \mathrm{O}_{10} \mathrm{ISi}_{3} \mathrm{Na} 1175.5332$; Found 1175.5330. 

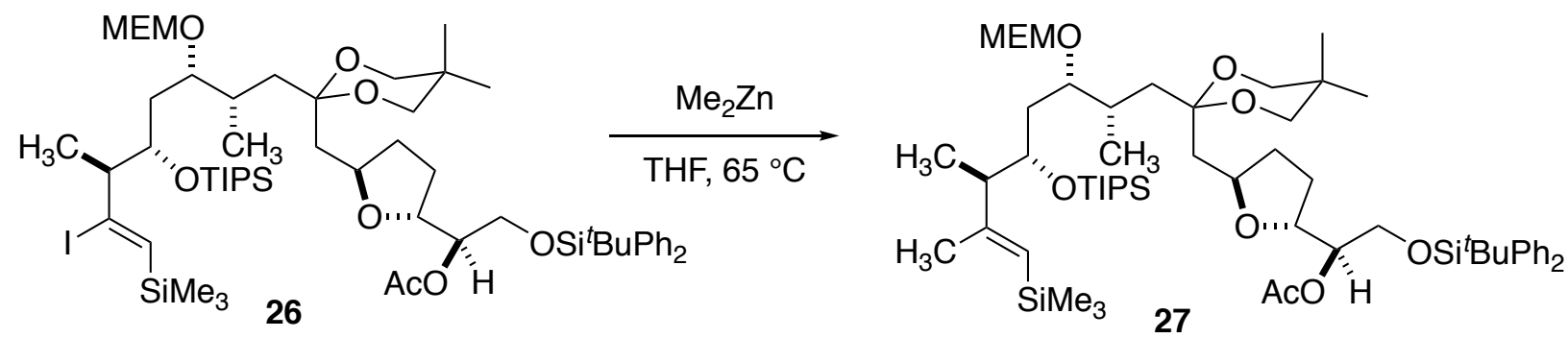

(R)-2-(Tert-butyldiphenylsilyloxy)-1-((2R,5R)-5-((2-((2S,3S,5S,6R,E)-3-((2-

methoxyethoxy)methoxy)-2,6,7-trimethyl-5-(triisopropylsilyloxy)-8-(trimethylsilyl)oct-7enyl)-5,5-dimethyl-1,3-dioxan-2-yl)methyl)tetrahydrofuran-2-yl)ethyl acetate (27).

Alkenyl iodide 26 (464 mg, $0.4023 \mathrm{mmol}$ ) was dissolved in THF (5.5 mL) and $\mathrm{Pd}\left(\mathrm{PPh}_{3}\right)_{4}$ (28 $\mathrm{mg}, 0.0242 \mathrm{mmol}$ ) was added in one portion at room temperature. A toluene solution of dimethylzinc $(0.5 \mathrm{~mL}, 1.0 \mathrm{mmol})$ was then added dropwise over 60 seconds. The reaction was transferred to $55{ }^{\circ} \mathrm{C}$ oil bath and stirred 3 hours prior to be cooled to $0{ }^{\circ} \mathrm{C}$. The reaction was quenched by dropwise addition of aqueous sodium bicarbonate and warmed to room temperature. Repeated diethyl ether extraction $(3 \times 15 \mathrm{~mL})$ was performed and the combined organics were dried over anhydrous sodium sulfate. The crude reaction mixture was purified by gradient column chromatography (silica gel, 5\% EtOAc/Hexanes; then 15\% EtOAc/Hexanes) to provide the silane 27 as an oil (402 mg, 96\%). TLC (ethyl acetate/hexanes 1:3) $\left.\mathrm{R}_{f}=0.6 ;{ }^{1} \mathrm{H} \mathrm{NMR} \mathrm{(400} \mathrm{MHz,} \mathrm{CDCl}_{3}\right)$

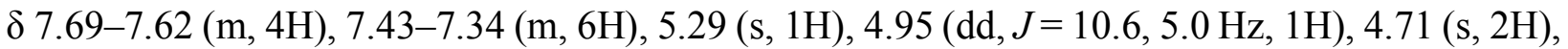
4.22 (app. q, $J=6.4 \mathrm{~Hz}, 1 \mathrm{H}), 4.15-4.01$ (m, 2H), 3.79 (app. d, $J=5.2 \mathrm{~Hz}, 2 \mathrm{H}), 3.76-3.69$ (m, 1H), 3.68-3.58 (m, 2H), 3.54-3.50 (m, 2H), $3.45(\mathrm{~s}, 4 \mathrm{H}), 3.36(\mathrm{~s}, 3 \mathrm{H}), 2.44-2.36(\mathrm{~m}, 1 \mathrm{H}), 2.17-1.95$ $(\mathrm{m}, 7 \mathrm{H}), 1.91(\mathrm{dd}, J=14.6,2.6 \mathrm{~Hz}, 1 \mathrm{H}), 1.85-1.78(\mathrm{~m}, 4 \mathrm{H}), 1.68-1.39(\mathrm{~m}, 5 \mathrm{H}), 1.09-1.03(\mathrm{~m}$, 33H), 0.96-0.92 (m, 6H), 0.90 (s, 3H), 0.09 (s, 9H); $\left.{ }^{13} \mathrm{C} \mathrm{NMR} \mathrm{(100} \mathrm{MHz,} \mathrm{CDCl}_{3}\right):$ 170.6, 156.5, $135.6,135.5,133.4,133.3,129.7,127.7,127.6,124.2,99.8,95.1,80.3,76.2,76.1,75.7,72.0,71.8$ $70.0,69.9,67.4,63.3,59.0,49.7,39.8,36.5,34.6,33.5,31.0,29.6,28.4,26.7,22.9,22.8,21.5$, 
$21.2,19.2,18.4,16.4,13.5,13.0,0.09$; IR (film) $v_{\max }: 2954,1742,1457,1238,1112 ;[\alpha]_{\mathrm{D}}^{25}-5.7$ $\left(c=1.0, \mathrm{CH}_{2} \mathrm{Cl}_{2}\right)$; HRMS (ESI) $m / z$ : $[\mathrm{M}+\mathrm{Na}]^{+}$Calcd for $\mathrm{C}_{58} \mathrm{H}_{100} \mathrm{O}_{10} \mathrm{Si}_{3} \mathrm{Na}$ 1063.6522; Found 1063.6558.
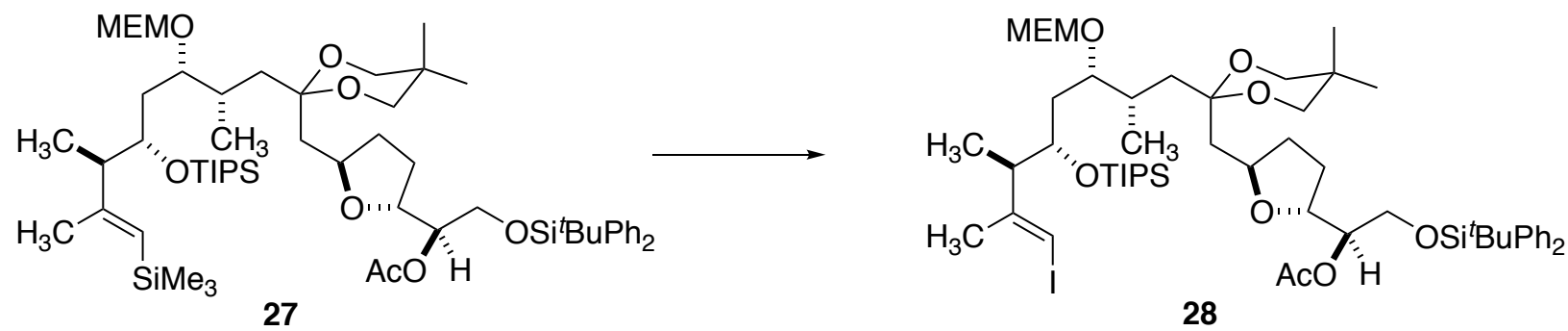

(R)-2-(Tert-butyldiphenylsilyloxy)-1-((2R,5R)-5-((2-((2S,3S,5S,6R,E)-8-iodo-3-((2methoxyethoxy)methoxy)-2,6,7-trimethyl-5-(triisopropylsilyloxy)oct-7-enyl)-5,5-dimethyl-

\section{1,3-dioxan-2-yl)methyl)tetrahydrofuran-2-yl)ethyl acetate (28).}

Alkenylsilane 27 (400 mg, $0.3840 \mathrm{mmol})$ was dissolved in THF (1.5 mL) and acetonitrile (3.0 mL), then 2,6-lutidine $(0.1 \mathrm{~mL})$ was added at room temperature. $N$-iodosuccinimide $(135 \mathrm{mg}$, $0.6000 \mathrm{mmol}$ ) was added in oned portion at room temperature with vigorous stirring. Additional NIS (45 mg, $0.2000 \mathrm{mmol}$ ) was added after three hours. At five hours, NIS (38 mg, $0.1689 \mathrm{mmol}$ [2.5 equivalents total]) was again added. After stirring seven hours, aqueous (saturated) sodium thiosulfate was added at room temperature. Diethyl ether extractions $(3 \times 20 \mathrm{~mL})$ were performed and the combined organics were dried over anhydrous sodium sulfate. Gradient column chromatography (silica gel, 5\% EtOAc/Hexanes, then rapidly increased to 25\% EtOAc/Hexanes) gave the desired alkenyliodide $\mathbf{2 8}$ as an oil (374 mg, 89\%). TLC (ethyl acetate/hexanes 1:3) $\mathrm{R}_{f}=$ $0.4 ;[\alpha]_{\mathrm{D}}^{25}-1.6\left(c 1.0, \mathrm{CH}_{2} \mathrm{Cl}_{2}\right) ;{ }^{1} \mathrm{H} \mathrm{NMR}\left(400 \mathrm{MHz}, \mathrm{CDCl}_{3}\right) \delta 7.66(\mathrm{t}, J=6.2 \mathrm{~Hz}, 4 \mathrm{H}), 7.44-7.33$ $(\mathrm{m}, 6 \mathrm{H}), 6.05(\mathrm{~s}, 1 \mathrm{H}), 4.97(\mathrm{dd}, J=10.6,5.0 \mathrm{~Hz}, 1 \mathrm{H}), 4.73(\mathrm{~d}, J=6.6 \mathrm{~Hz}, 1 \mathrm{H}), 4.69(\mathrm{~d}, J=6.6 \mathrm{~Hz}$, 1H), 4.23 (dd, $J=13.0,7.0 \mathrm{~Hz}, 1 \mathrm{H}), 4.12-4.03(\mathrm{~m}, 1 \mathrm{H}), 4.02-3.97$ (m, 1H), 3.81 (app. d, $J=4.8$ Hz, 2H), 3.74-3.63 (m, 2H), 3.63-3.57 (m, 1H), 3.56-3.52 (m, 2H), $3.49(\mathrm{~d}, 11.2 \mathrm{~Hz}, 2 \mathrm{H}), 3.42$ 
$(\mathrm{d}, J=11.2 \mathrm{~Hz}, 2 \mathrm{H}), 3.38(\mathrm{~s}, 3 \mathrm{H}), 2.67-2.58(\mathrm{~m}, 1 \mathrm{H}), 2.16-1.78(\mathrm{~m}, 14 \mathrm{H}), 1.70-1.57(\mathrm{~m}, 1 \mathrm{H})$, 1.57-1.52 (m, 2H), $1.43(\mathrm{dd}, J=14.0,6.8 \mathrm{~Hz}, 1 \mathrm{H}), 1.12(\mathrm{~d}, J=6.4 \mathrm{~Hz}, 3 \mathrm{H}), 1.08(\mathrm{~s}, 21 \mathrm{H}), 1.04$ (s, 9H), $0.98(\mathrm{~s}, 3 \mathrm{H}), 0.95$ (d, $J=6.4 \mathrm{~Hz}, 3 \mathrm{H}), 0.87(\mathrm{~s}, 3 \mathrm{H}) ;{ }^{13} \mathrm{C}$ NMR $\left(100 \mathrm{MHz}, \mathrm{CDCl}_{3}\right): 170.5$, 149.4, 135.5, 135.5, 133.3, 133.2, 129.6, 127.6, 127.6, 99.8, 94.9, 79.8, 77.6, 76.2, 76.0, 75.6, 72.6, 71.8, 70.0, 69.9, 67.4, 63.2, 59.0, 47.9, 39.0, 37.3, 23.0, 22.7, 21.1, 19.1, 18.3, 16.4, 14.7, 12.9; IR (film) $v_{\max }: 2942,2866,1743,1465,1427,1366,1237,1112,1040,833,824,740,702,681 \mathrm{~cm}^{-1}$; HRMS (ESI) m/z: [M+Na] $]^{+}$Calcd for $\mathrm{C}_{55} \mathrm{H}_{91} \mathrm{IO}_{10} \mathrm{Si}_{2} \mathrm{Na}$ 1117.5093; Found 1117.5089. 


\section{TBDPSO OTBS

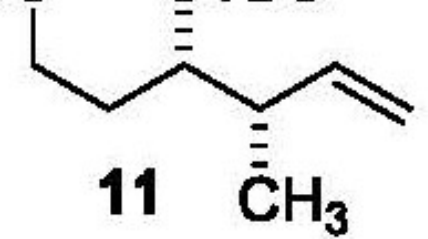

[Scheme 3]

${ }^{1} \mathrm{H} \mathrm{NMR}\left(400 \mathrm{MHz}, \mathrm{CDCl}_{3}\right)$ $)$ 7.67-7.64 (m, 4H), 7.42-7.34 (m, 6H), 5.91-5.82 (m,

$1 \mathrm{H}), 5.00-4.94(\mathrm{~m}, 2 \mathrm{H}), 3.81-3.77(\mathrm{~m}, 1 \mathrm{H}), 3.73-3.67(\mathrm{~m}, 3 \mathrm{H}), 2.32-2.28(\mathrm{~m}, 1 \mathrm{H})$,

$1.69-1.54(\mathrm{~m}, 2 \mathrm{H}), 1.28-1.24(\mathrm{~m}, 2 \mathrm{H}), 1.04$ (s, 9H), 0.94 (d, $J=6.8 \mathrm{~Hz}, 3 \mathrm{H}), 0.85$ (s,

$9 \mathrm{H}), 0.03(\mathrm{~s}, 3 \mathrm{H}),-0.01(\mathrm{~s}, 3 \mathrm{H})$ 
${ }^{13} \mathrm{C} \mathrm{NMR}\left(100 \mathrm{MHz}, \mathrm{CDCl}_{3}\right) \delta 141.4,135.8,134.3,134.2,129.7,127.8,114.2,72.9,64.9,61.1,43.0,36.6$,

$27.1,26.2,19.4,18.3,14.8,-4.2,-4.3$ 


\section{TBDPSO OTBS

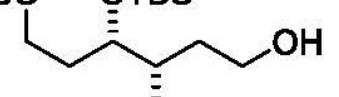 \\ 11a $\overline{\mathrm{C}} \mathrm{H}_{3}$}

[Scheme 3\}

${ }^{1} \mathrm{H} \mathrm{NMR}\left(400 \mathrm{MHz}, \mathrm{CDCl}_{3}\right) \delta$ 7.69-7.66 (m, 4H), 7.46-7.38 (m, 6H), 3.89-3.86 (m, 1H),

$3.73(\mathrm{t}, J=6.4 \mathrm{~Hz}, 2 \mathrm{H}), 3.68(\mathrm{~m}, 1 \mathrm{H}), 3.64-3.59(\mathrm{~m}, 1 \mathrm{H}), 2.67(\mathrm{br} \mathrm{s}, 1 \mathrm{H}), 1.80-1.74(\mathrm{~m}, 2 \mathrm{H})$,

$1.70-1.64(\mathrm{~m}, 2 \mathrm{H}), 1.40-1.36(\mathrm{~m}, 1 \mathrm{H}), 1.07(\mathrm{~s}, 9 \mathrm{H}), 0.88(\mathrm{~s}, 9 \mathrm{H}), 0.88(\mathrm{~d}, J=6.8 \mathrm{~Hz}, 3 \mathrm{H})$,

$0.09(\mathrm{~s}, 3 \mathrm{H}), 0.04(\mathrm{~s}, 3 \mathrm{H})$ 


\section{TBDPSO \\ OTBS

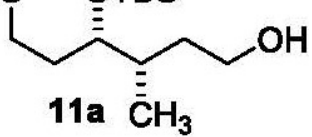

\section{[Scheme 3]}

${ }^{13} \mathrm{C} \mathrm{NMR}\left(100 \mathrm{MHz}, \mathrm{CDCl}_{3}\right) \delta$ 135.7, 134.2, 129.7, 127.8, 73.2, 62.2, 60.2, 37.6, 35.6, 35.1, $27.1,26.1,19.4,18.2,17.3,-3.8,-4.5$

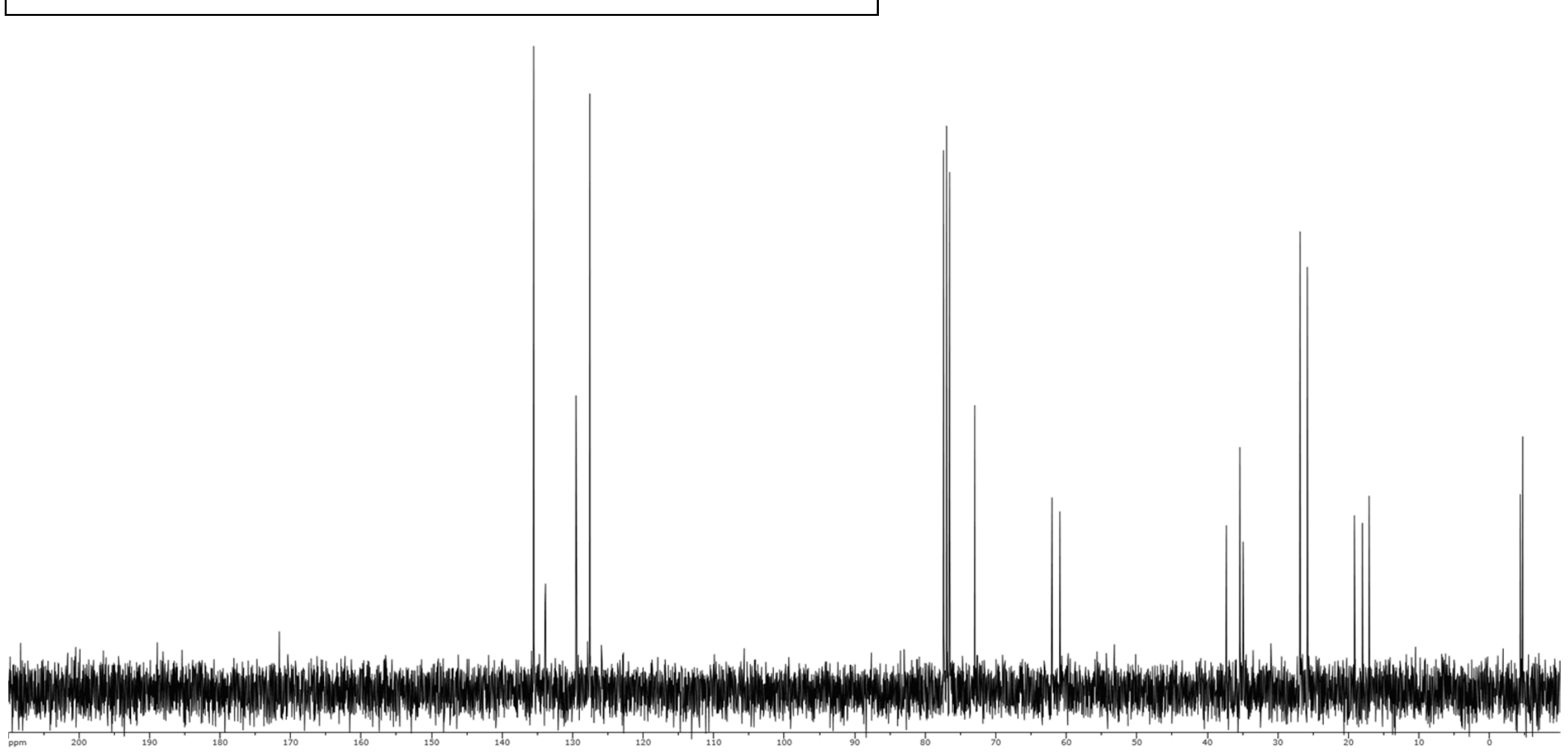




\section{TBDPSO OTBS

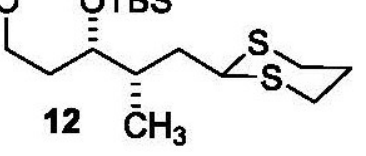

\section{[Scheme 3]}

${ }^{1} \mathrm{H} \mathrm{NMR}\left(400 \mathrm{MHz}, \mathrm{CDCl}_{3}\right) \delta 7.69-7.65(\mathrm{~m}, 4 \mathrm{H}), 7.43-7.35(\mathrm{~m}, 6 \mathrm{H}), 4.08(\mathrm{dd}, J=9.2,5.6 \mathrm{~Hz}, 1 \mathrm{H})$, 3.87-3.83 (m, 1H), $3.70(\mathrm{t}, J=6.2 \mathrm{~Hz}, 2 \mathrm{H}), 2.91-2.78(\mathrm{~m}, 4 \mathrm{H}), 2.13-2.08(\mathrm{~m}, 1 \mathrm{H}), 2.08-1.85(\mathrm{~m}, 3 \mathrm{H})$,

$1.67-1.48(\mathrm{~m}, 3 \mathrm{H}), 1.06(\mathrm{~s}, 9 \mathrm{H}), 0.86(\mathrm{~s}, 9 \mathrm{H}), 0.84(\mathrm{~d}, \mathrm{~J}=6.8 \mathrm{~Hz}, 3 \mathrm{H}), 0.07(\mathrm{~s}, 3 \mathrm{H}), 0.01(\mathrm{~s}, 3 \mathrm{H})$ 


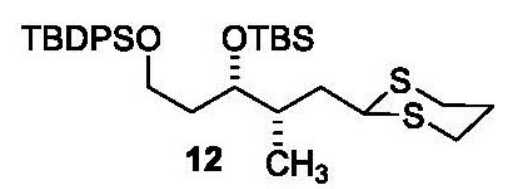

[Scheme 3]

${ }^{13} \mathrm{C} \mathrm{NMR}\left(100 \mathrm{MHz}, \mathrm{CDCl}_{3}\right) \delta 135.8,134.2,129.8,127.8,72.2,61.3$,

$46.0,38.0,36.2,35.0,30.8,30.5,27.1,26.4,26.2,19.4,18.3,14.6,-4.1,-4.3$

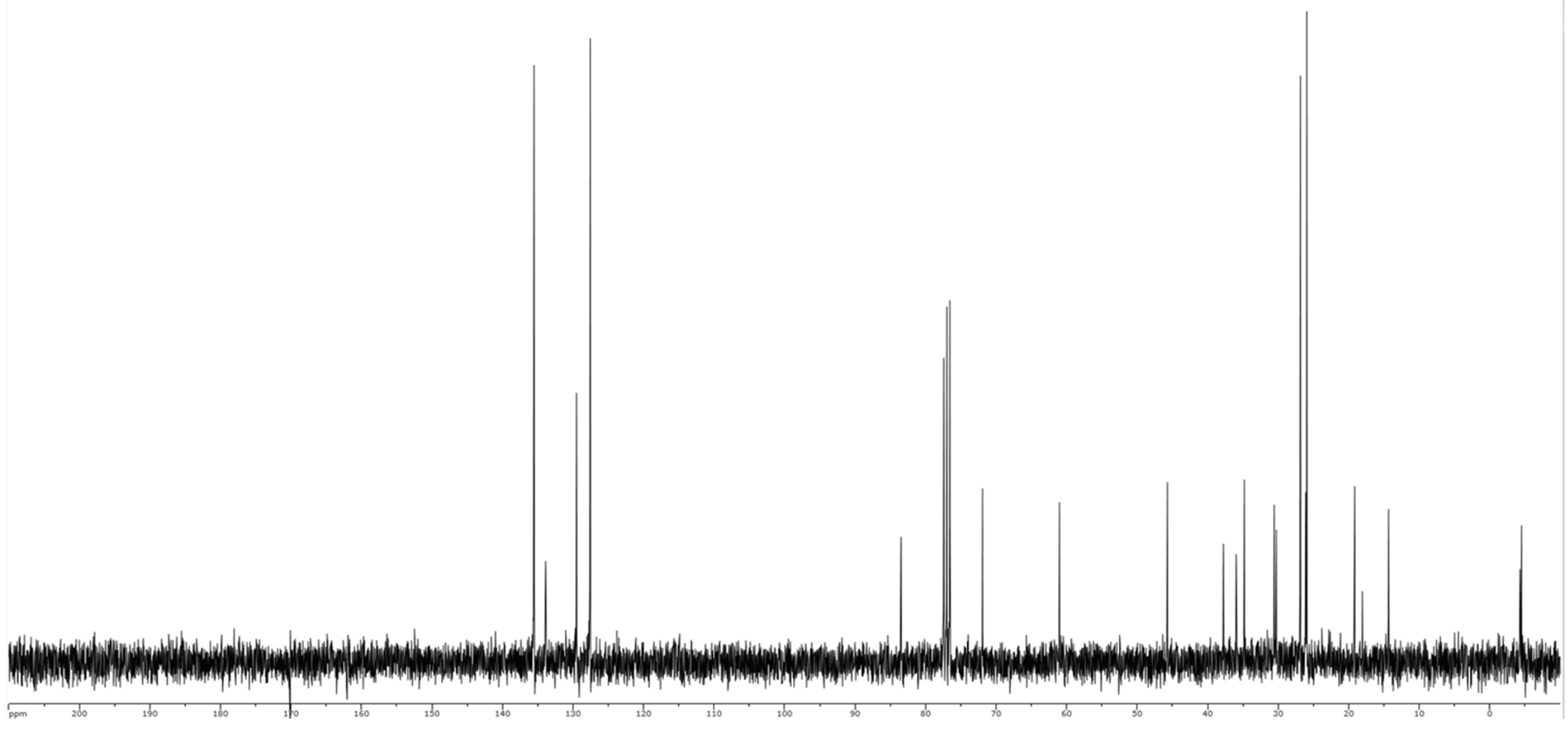




\begin{tabular}{|lll|}
\hline \multicolumn{1}{|c}{ Parameter } & \multicolumn{1}{c|}{ Value } \\
1 & Origin & Varian \\
2 & Spectrometer & vxrs \\
3 & Solvent & cdcl3 \\
4 & Temperature & 25.0 \\
5 & Experiment & $1 \mathrm{D}$ \\
6 & Number of Scans & 16 \\
7 & Relaxation Delay & 1.0000 \\
8 & Spectrometer & 399.75 \\
& Frequency & \\
9 & Spectral Width & 5999.7 \\
10 & Lowest Frequency & -1000.5 \\
11 & Nucleus & $1 \mathrm{H}$ \\
12 Acquired Size & 11999 \\
13 & Spectral Size & 65536 \\
\hline
\end{tabular}

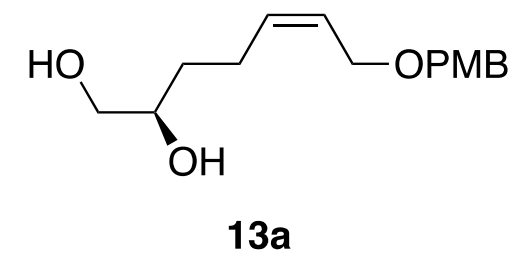

${ }^{1} \mathrm{H}$ NMR (400 MHz, CDCl 3$) \delta$ 7.40-7.17 (m, 2H), 6.99-6.75 (m, 2H), 5.80-5.49 (m, $2 \mathrm{H}), 4.46(\mathrm{~s}, 2 \mathrm{H}), 4.10(\mathrm{dd}, J=11.5,6.6 \mathrm{~Hz}, 1 \mathrm{H}), 3.96(\mathrm{dd}, J=11.6,6.3 \mathrm{~Hz}, 1 \mathrm{H}), 3.80$ (s, $3 \mathrm{H}), 3.66(\mathrm{qt}, J=9.2,4.9 \mathrm{~Hz}, 1 \mathrm{H}), 3.56(\mathrm{dd}, J=11.0,3.2 \mathrm{~Hz}, 1 \mathrm{H}), 3.40(\mathrm{dt}, J=$ $11.0,7.1 \mathrm{~Hz}, 1 \mathrm{H}), 3.01(\mathrm{~s}, 2 \mathrm{H}), 2.22(\mathrm{ddt}, J=49.8,13.6,6.6 \mathrm{~Hz}, 2 \mathrm{H}), 1.57-1.34(\mathrm{~m}$, 2H)

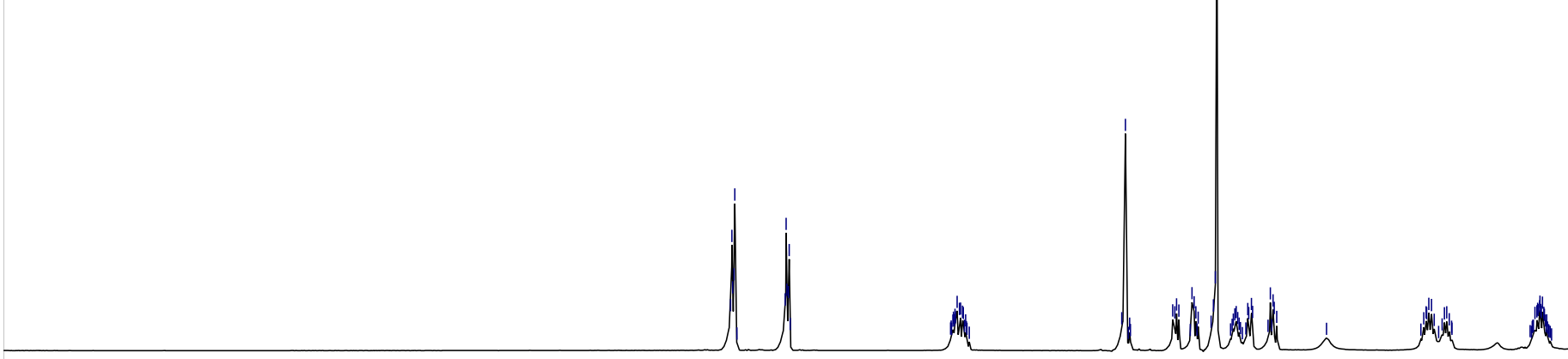




\begin{tabular}{|lll|}
\hline \multicolumn{1}{|c}{ Parameter } & \multicolumn{1}{c|}{ Value } \\
1 & Origin & Varian \\
2 & Spectrometer & vxrs \\
3 & Solvent & cdcl3 \\
4 & Temperature & 25.0 \\
5 & Experiment & $1 \mathrm{D}$ \\
6 & Number of Scans & 16 \\
7 & Relaxation Delay & 1.0000 \\
8 & Spectrometer Frequency & 399.75 \\
9 & Spectral Width & 5999.7 \\
10 & Lowest Frequency & -998.3 \\
11 & Nucleus & $1 \mathrm{H}$ \\
12 & Acquired Size & 11999 \\
13 Spectral Size & 65536 \\
\hline
\end{tabular}

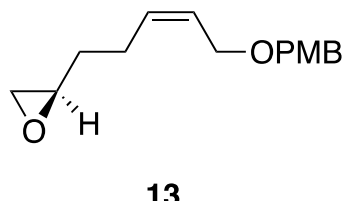

${ }^{1} \mathrm{H}$ NMR $\left(400 \mathrm{MHz}, \mathrm{CDCl}_{3}\right)$ d 7.37-7.09 (m, 2H), 6.96-6.78 (m, 2H), 5.75-5.49 (m, $2 \mathrm{H}), 4.45(\mathrm{~s}, 2 \mathrm{H}), 4.14-4.00(\mathrm{~m}, 2 \mathrm{H}), 3.81(\mathrm{~s}, 3 \mathrm{H}), 2.97-2.84(\mathrm{~m}, 1 \mathrm{H}), 2.75(\mathrm{t}, J=4.5$ $\mathrm{Hz}, 1 \mathrm{H}), 2.47(\mathrm{dd}, J=5.0,2.7 \mathrm{~Hz}, 1 \mathrm{H}), 2.29-2.13(\mathrm{~m}, 2 \mathrm{H}), 1.72-1.50(\mathrm{~m}, 2 \mathrm{H})$ 


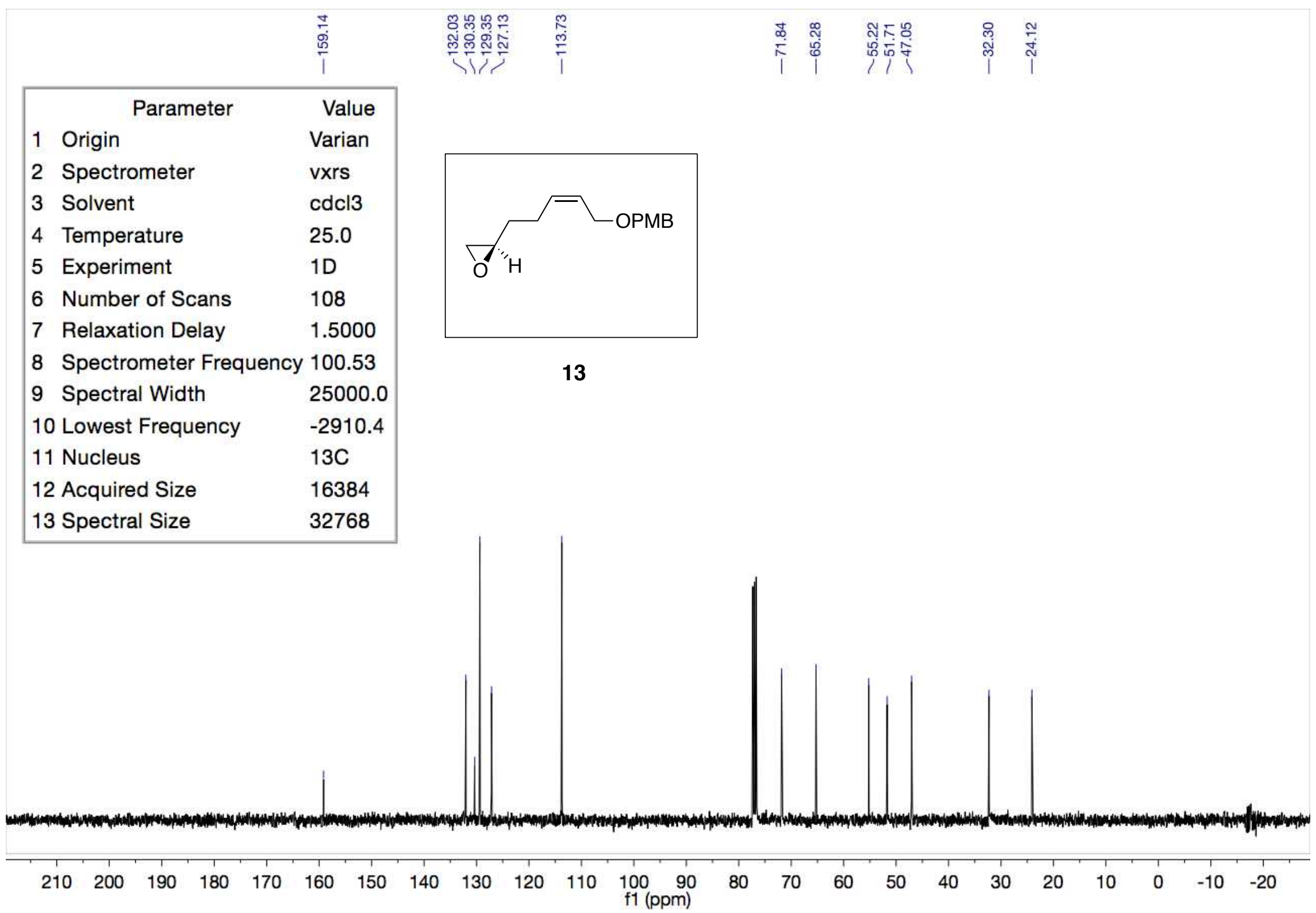


Williams et al.

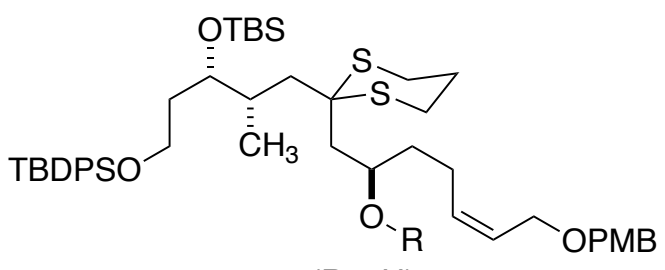

14a $(R=H)$

[Scheme 4]

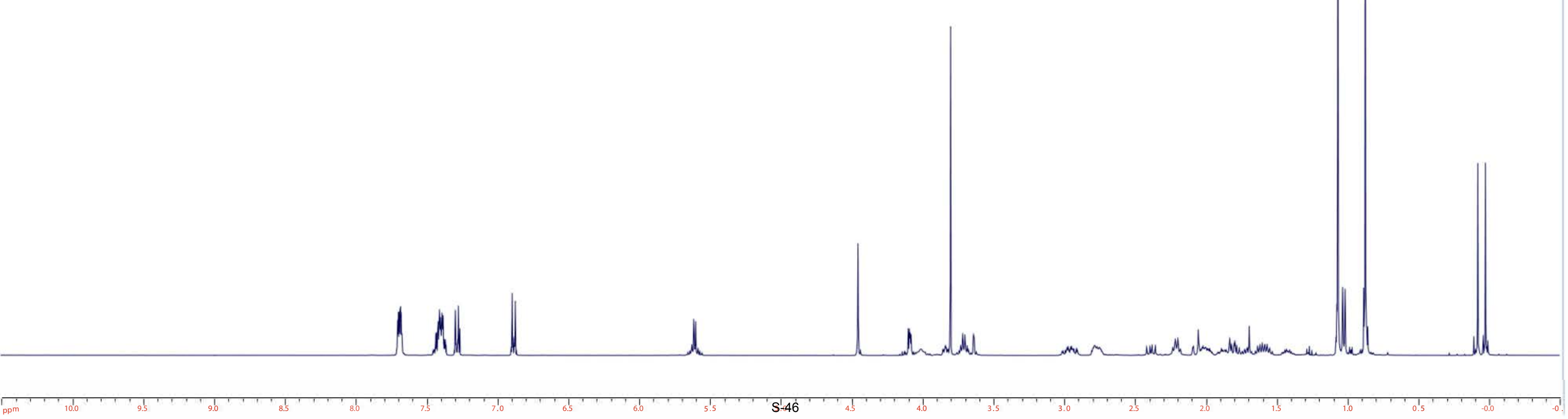




\begin{tabular}{|lll|}
\hline \multicolumn{1}{|c}{ Parameter } & $\begin{array}{c}\text { Value } \\
\text { Varian } \\
1\end{array}$ Origin & inova \\
2 & Spectrometer & cdcl3 \\
3 & Solvent & 25.0 \\
4 & Temperature & $1 \mathrm{D}$ \\
5 & Experiment & 16 \\
6 & Number of Scans & 1.0000 \\
7 & Relaxation Delay & 400.12 \\
8 & Spectrometer Frequency \\
9 & Spectral Width & 6402.0 \\
10 Lowest Frequency & -806.2 \\
11 Nucleus & $1 \mathrm{H}$ \\
12 Acquired Size & 12824 \\
13 Spectral Size & 65536 \\
\hline
\end{tabular}

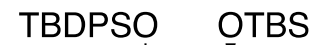

${ }^{1} \mathrm{H}$ NMR $\left(400 \mathrm{MHz}, \mathrm{CDCl}_{3}\right) \delta 7.69(\mathrm{ddt}, J=7.9,3.3,1.7 \mathrm{~Hz}, 4 \mathrm{H}), 7.47-7.31(\mathrm{~m}, 6 \mathrm{H})$ $7.31-7.23(\mathrm{~m}, 2 \mathrm{H}), 6.98-6.70(\mathrm{~m}, 2 \mathrm{H}), 5.60(\mathrm{q}, J=6.4,5.9 \mathrm{~Hz}, 2 \mathrm{H}), 4.45(\mathrm{~s}, 2 \mathrm{H})$

4.14-4.05 (m, 2H), 4.05-3.95 (m, 1H), $3.84(\mathrm{td}, J=5.2,2.7 \mathrm{~Hz}, 1 \mathrm{H}), 3.80(\mathrm{~s}, 3 \mathrm{H})$, $3.70(\mathrm{q}, J=6.3 \mathrm{~Hz}, 2 \mathrm{H}), 3.63(\mathrm{dd}, J=2.1,1.0 \mathrm{~Hz}, 1 \mathrm{H}), 2.96(\mathrm{dddd}, J=17.0,14.2$, 9.7, $3.0 \mathrm{~Hz}, 2 \mathrm{H}), 2.84-2.67(\mathrm{~m}, 2 \mathrm{H}), 2.38(\mathrm{dd}, J=15.2,9.3 \mathrm{~Hz}, 1 \mathrm{H}), 2.20(\mathrm{q}, J=6.8$, $6.4 \mathrm{~Hz}, 2 \mathrm{H}), 2.11-1.94(\mathrm{~m}, 3 \mathrm{H}), 1.92-1.66(\mathrm{~m}, 4 \mathrm{H}), 1.66-1.50(\mathrm{~m}, 2 \mathrm{H}), 1.48-1.35(\mathrm{~m}$, $1 \mathrm{H}), 1.07(\mathrm{~s}, 9 \mathrm{H}), 1.02(\mathrm{~d}, J=6.8 \mathrm{~Hz}, 3 \mathrm{H}), 0.87(\mathrm{~s}, 9 \mathrm{H}), 0.08(\mathrm{~s}, 3 \mathrm{H}), 0.02(\mathrm{~s}, 3 \mathrm{H})$
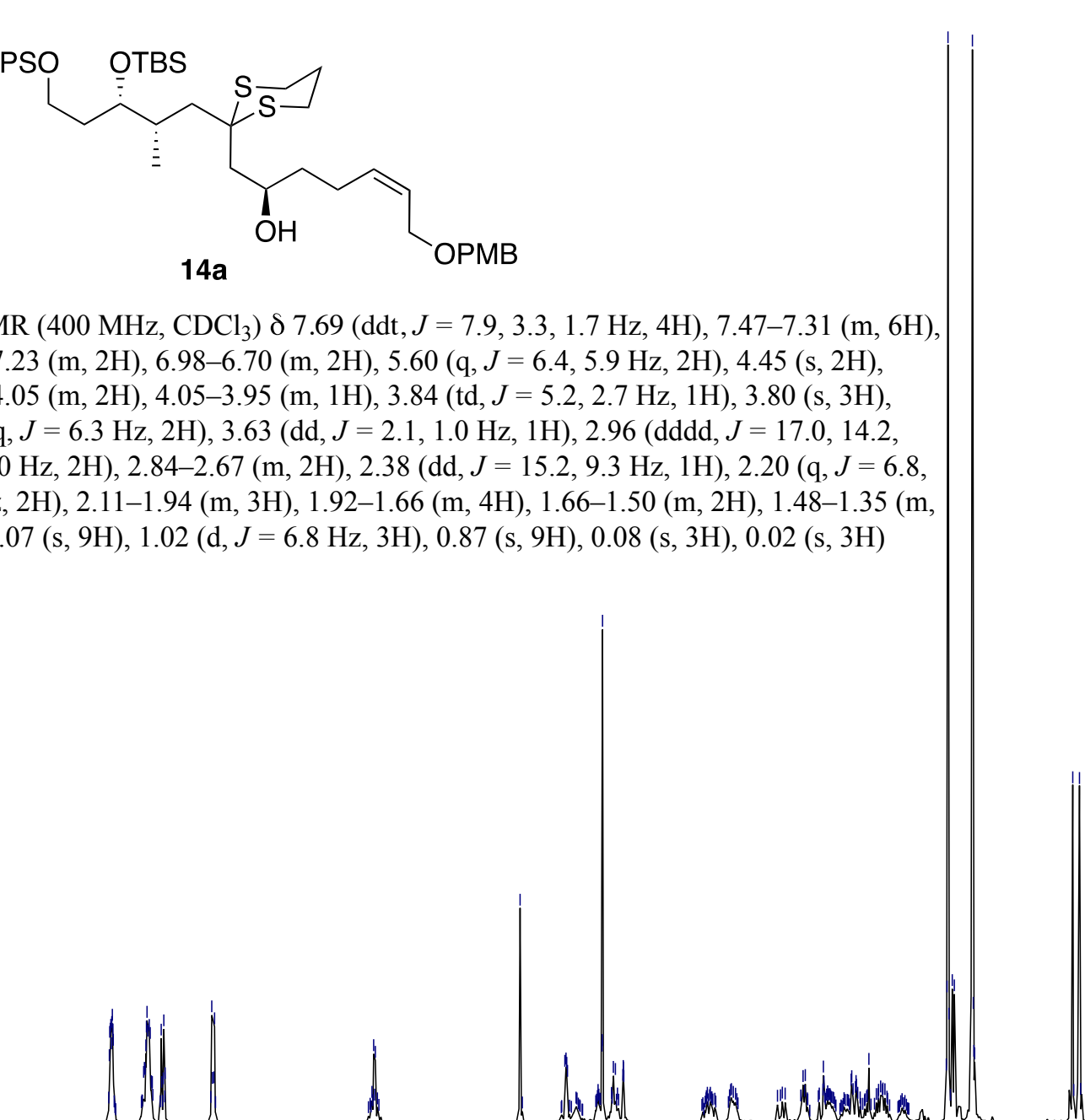

13

12

11

10

9

8

7

6
f1- $(\mathrm{ppm})$

5

(

3

3

2

1 


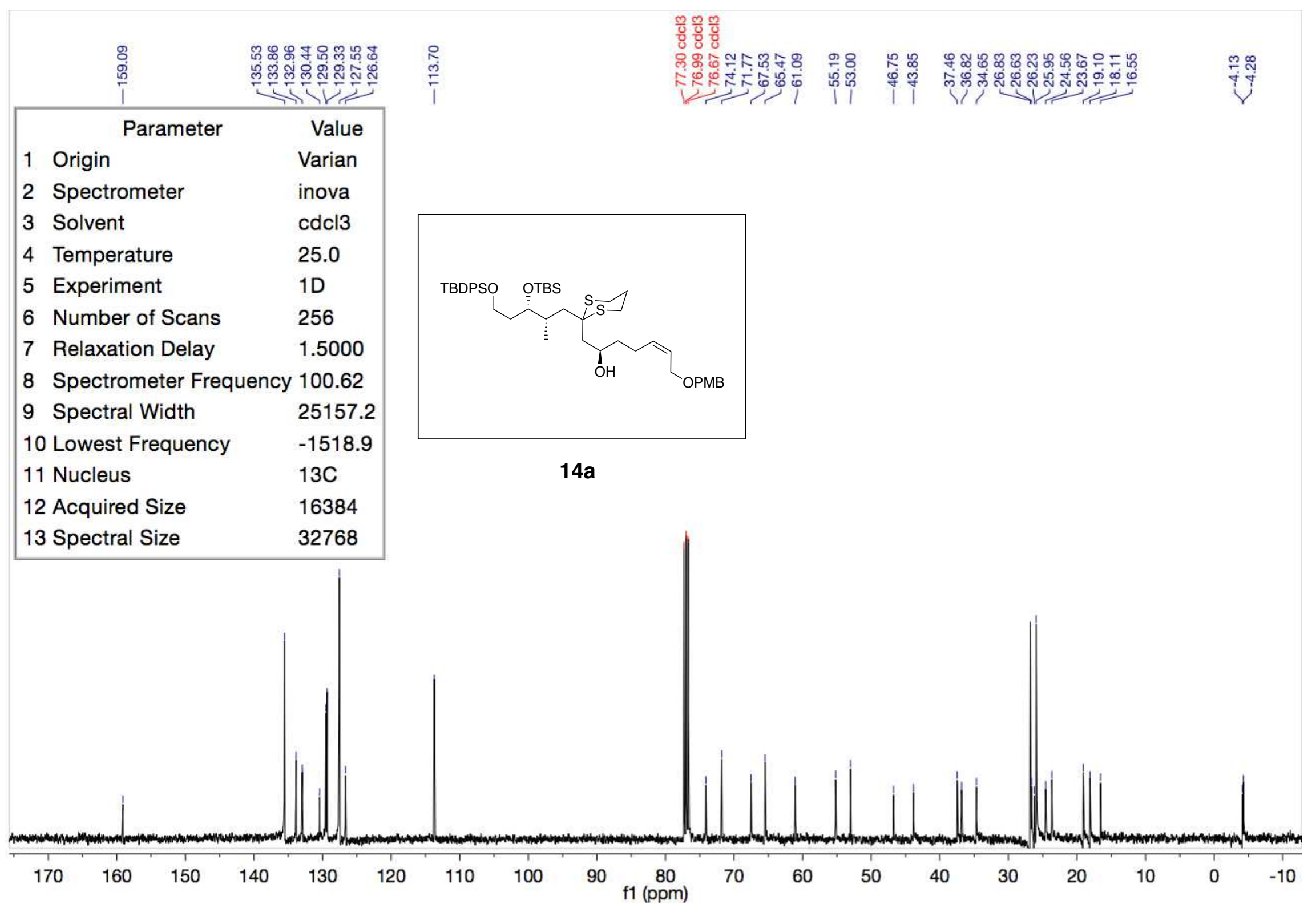




$$
\text { TBDPSO }
$$

14b ( $R=M O M)$

[Scheme 4]

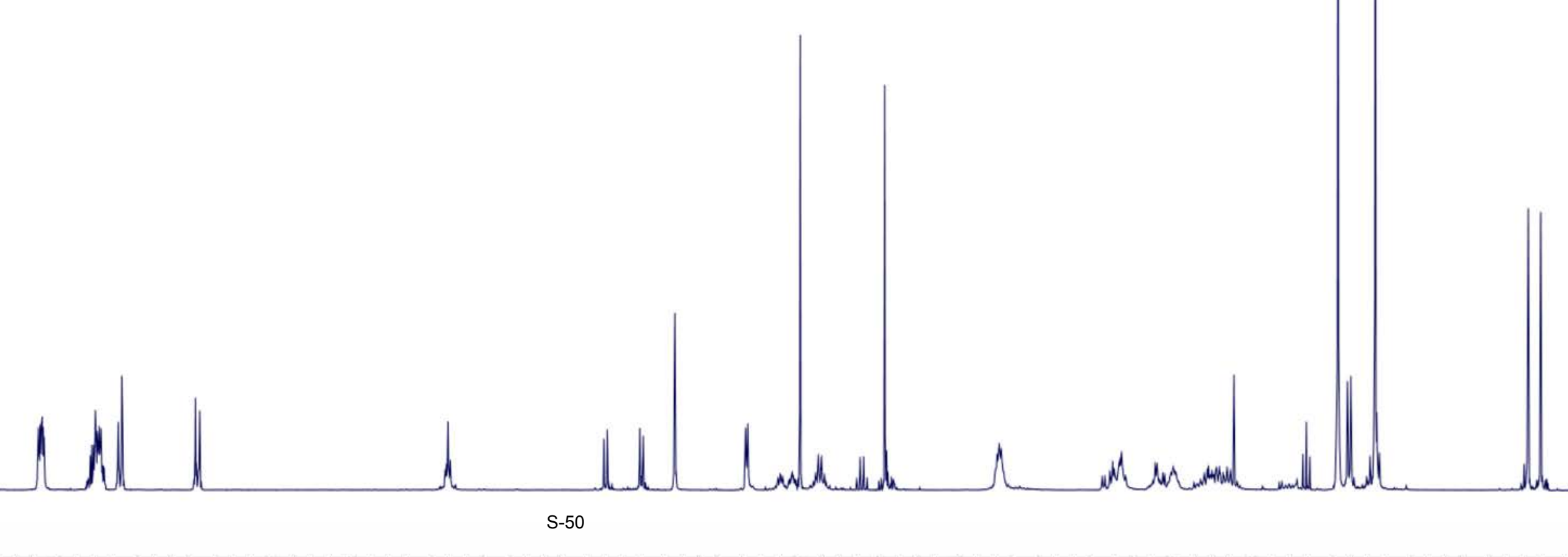




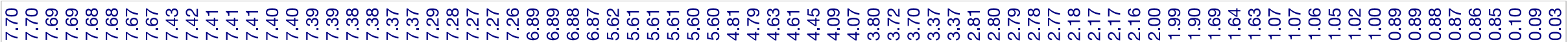

\begin{tabular}{|c|c|c|}
\hline & Parameter & Value \\
\hline 1 & Origin & Varian \\
\hline 2 & Spectrometer & vxrs \\
\hline 3 & Solvent & $\mathrm{cdcl} 3$ \\
\hline 4 & Temperature & 25.0 \\
\hline 5 & Experiment & $1 \mathrm{D}$ \\
\hline 6 & Number of Scans & 16 \\
\hline 7 & Relaxation Delay & 1.0000 \\
\hline 8 & Spectrometer Frequency & 399.74 \\
\hline 9 & Spectral Width & 5999.7 \\
\hline & Lowest Frequency & -1001.3 \\
\hline & Nucleus & $1 \mathrm{H}$ \\
\hline & Acquired Size & 11999 \\
\hline & Spectral Size & 65536 \\
\hline
\end{tabular}

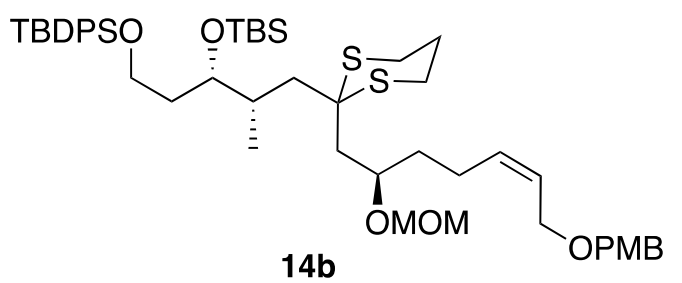

${ }^{1} \mathrm{H}$ NMR $\left(400 \mathrm{MHz}, \mathrm{CDCl}_{3}\right) \delta 7.68$ (ddd, $\left.J=7.8,3.3,1.6 \mathrm{~Hz}, 4 \mathrm{H}\right), 7.39$ (dddd, $J=$ $12.0,9.8,5.8,2.2 \mathrm{~Hz}, 6 \mathrm{H}), 7.32-7.18(\mathrm{~m}, 2 \mathrm{H}), 6.93-6.80(\mathrm{~m}, 2 \mathrm{H}), 5.61(\mathrm{td}, J=4.1$, $2.2 \mathrm{~Hz}, 2 \mathrm{H}), 4.84-4.74(\mathrm{~m}, 1 \mathrm{H}), 4.65-4.54(\mathrm{~m}, 1 \mathrm{H}), 4.45(\mathrm{~s}, 2 \mathrm{H}), 4.08(\mathrm{~d}, J=4.5 \mathrm{~Hz}$ $2 \mathrm{H}), 3.95-3.88(\mathrm{~m}, 1 \mathrm{H}), 3.85(\mathrm{p}, J=2.8 \mathrm{~Hz}, 1 \mathrm{H}), 3.80(\mathrm{~s}, 3 \mathrm{H}), 3.70(\mathrm{dt}, J=10.7,5.0$ $\mathrm{Hz}, 2 \mathrm{H}), 3.37$ (s, 3H), $2.79(\mathrm{dq}, J=5.7,3.3,2.5 \mathrm{~Hz}, 4 \mathrm{H}), 2.30-2.10(\mathrm{~m}, 4 \mathrm{H}), 2.07-$ $1.93(\mathrm{~m}, 2 \mathrm{H}), 1.90(\mathrm{p}, J=6.1 \mathrm{~Hz}, 2 \mathrm{H}), 1.82-1.54(\mathrm{~m}, 5 \mathrm{H}), 1.06(\mathrm{~s}, 9 \mathrm{H}), 1.01(\mathrm{~d}, J=$ $6.8 \mathrm{~Hz}, 3 \mathrm{H}), 0.87$ (s, 9H), 0.09 (s, 3H), $0.03(\mathrm{~s}, 3 \mathrm{H})$

10 Lowest Frequency
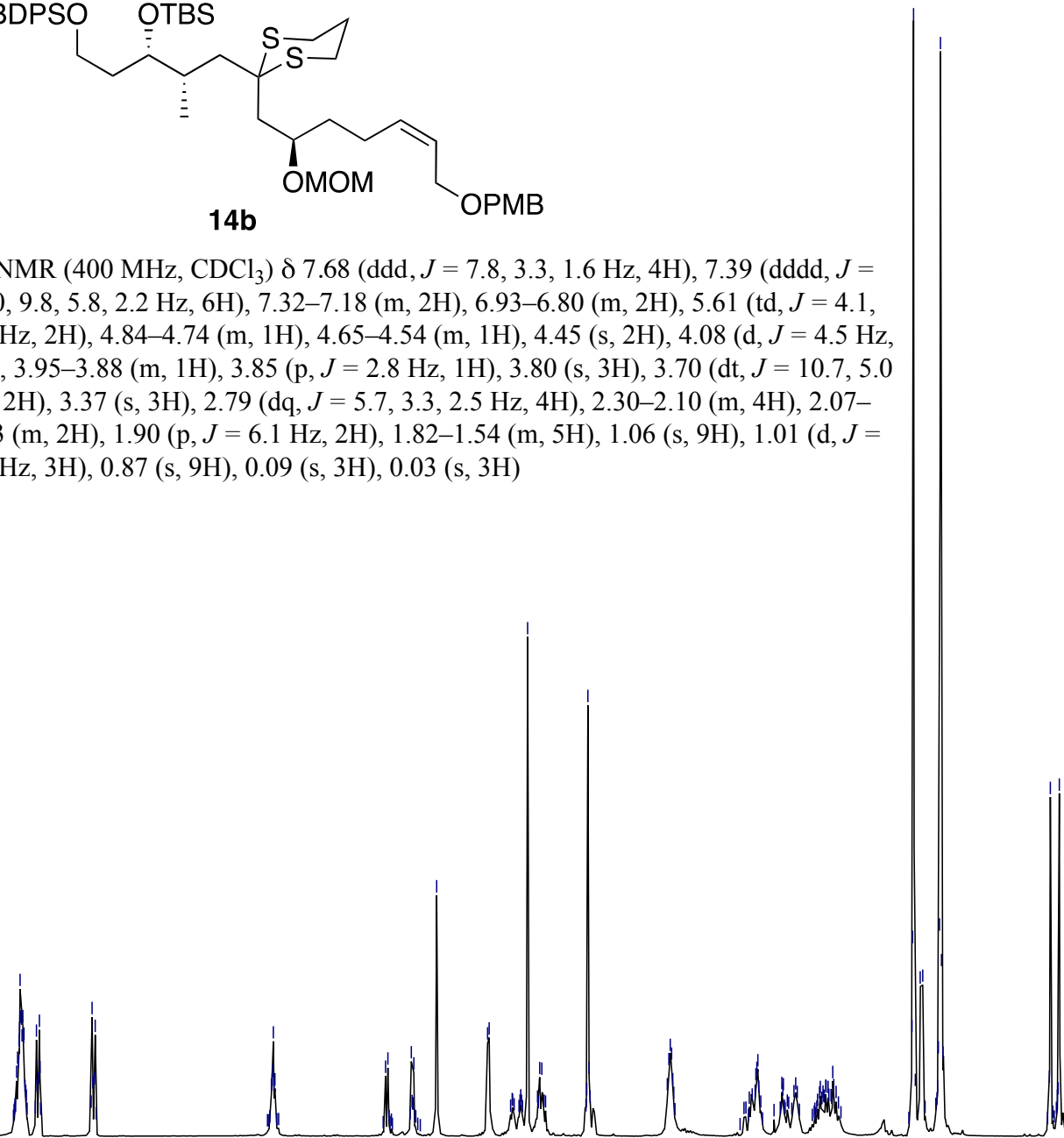

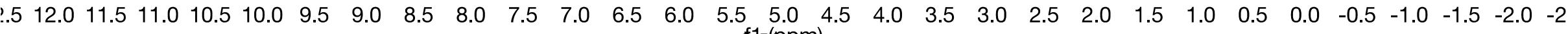
$\$ 15(\mathrm{ppm})$ 


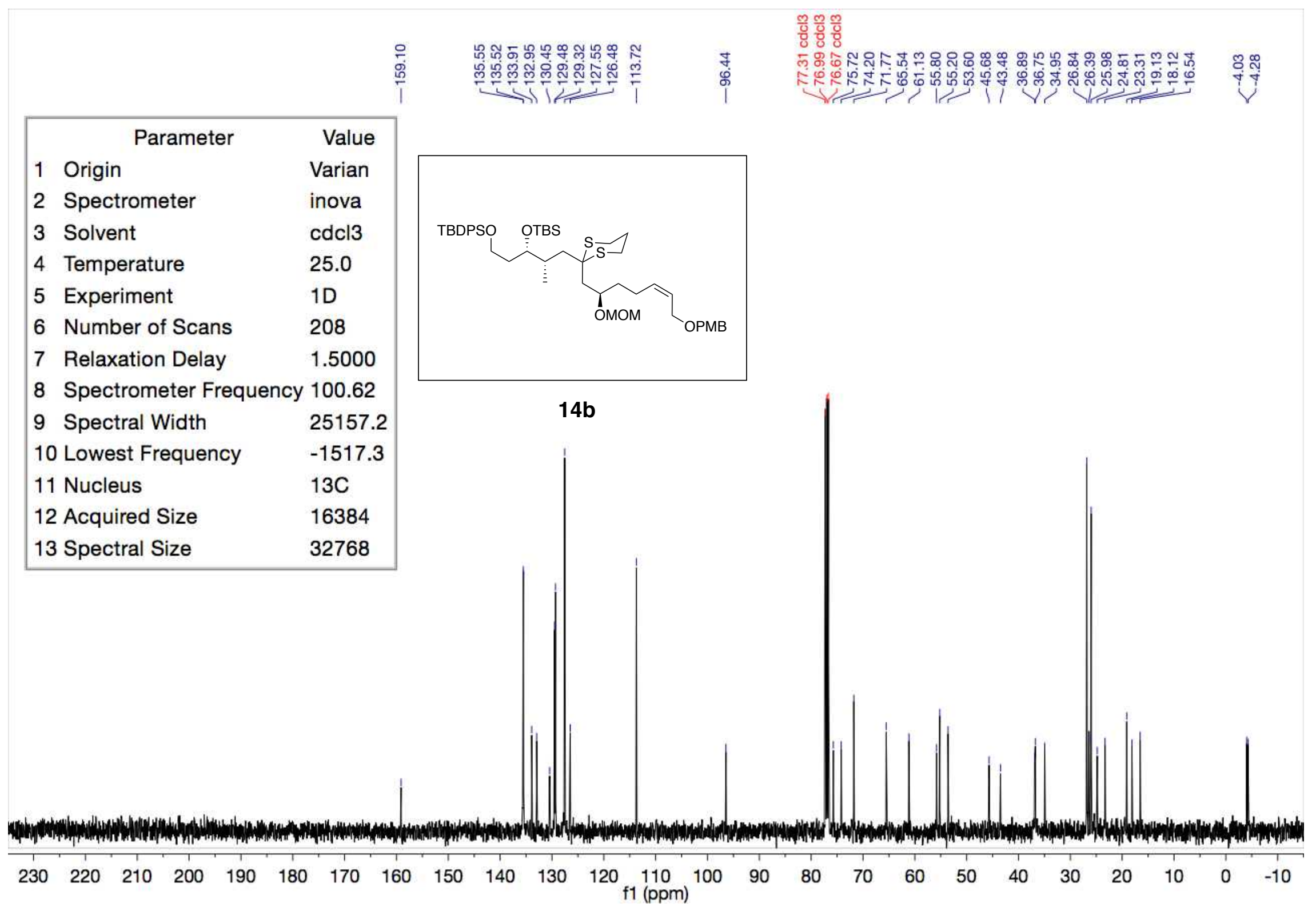




\begin{tabular}{|lll|}
\hline & \multicolumn{1}{|c}{ Parameter } & \multicolumn{1}{c|}{ Value } \\
1 & Origin & Varian \\
2 & Spectrometer & vxrs \\
3 & Solvent & cdcl3 \\
4 & Temperature & 25.0 \\
5 & Experiment & $1 \mathrm{D}$ \\
6 & Number of Scans & 16 \\
7 & Relaxation Delay & 1.0000 \\
8 & Spectrometer Frequency & 399.74 \\
9 & Spectral Width & 5999.7 \\
10 Lowest Frequency & -1000.6 \\
11 Nucleus & $1 \mathrm{H}$ \\
12 Acquired Size & 11999 \\
13 Spectral Size & 65536 \\
\hline
\end{tabular}

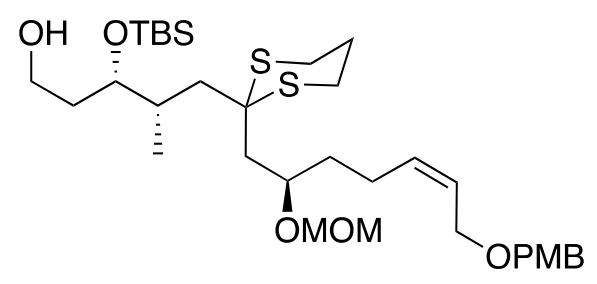

14c

${ }^{1} \mathrm{H}$ NMR $\left(400 \mathrm{MHz}, \mathrm{CDCl}_{3}\right) \delta 7.27$ (d, $\left.J=7.0,1.4 \mathrm{~Hz}, 2 \mathrm{H}\right), 6.92-6.79(\mathrm{~d}, 2 \mathrm{H}), 5.66-$ $5.51(\mathrm{~m}, 2 \mathrm{H}), 4.78(\mathrm{~d}, J=6.8 \mathrm{~Hz}, 1 \mathrm{H}), 4.62(\mathrm{~d}, J=6.8 \mathrm{~Hz}, 1 \mathrm{H}), 4.44(\mathrm{~s}, 2 \mathrm{H}), 4.07(\mathrm{~d}$, $J=4.6 \mathrm{~Hz}, 2 \mathrm{H}), 3.87(\mathrm{dd}, J=5.7,4.0 \mathrm{~Hz}, 1 \mathrm{H}), 3.82(\mathrm{dd}, J=6.5,2.6 \mathrm{~Hz}, 1 \mathrm{H}), 3.80(\mathrm{~s}$, $3 \mathrm{H}), 3.69$ (p, $J=5.3,4.9 \mathrm{~Hz}, 2 \mathrm{H}), 3.37(\mathrm{~s}, 3 \mathrm{H}), 2.79(\mathrm{td}, J=5.0,2.9 \mathrm{~Hz}, 4 \mathrm{H}), 2.28(\mathrm{~d}$, $J=5.6 \mathrm{~Hz}, 1 \mathrm{H}), 2.24(\mathrm{~d}, J=5.7 \mathrm{~Hz}, 1 \mathrm{H}), 2.16(\mathrm{dq}, J=10.8,4.6,3.0 \mathrm{~Hz}, 4 \mathrm{H}), 2.06-$ $1.97(\mathrm{~m}, 2 \mathrm{H}), 1.91(\mathrm{q}, J=4.7 \mathrm{~Hz}, 1 \mathrm{H}), 1.81(\mathrm{t}, J=5.4 \mathrm{~Hz}, 1 \mathrm{H}), 1.75-1.61(\mathrm{~m}, 4 \mathrm{H})$, $1.07-0.96(\mathrm{~m}, 3 \mathrm{H}), 0.90(\mathrm{~s}, 9 \mathrm{H}), 0.11(\mathrm{~s}, 3 \mathrm{H}), 0.09(\mathrm{~s}, 3 \mathrm{H})$

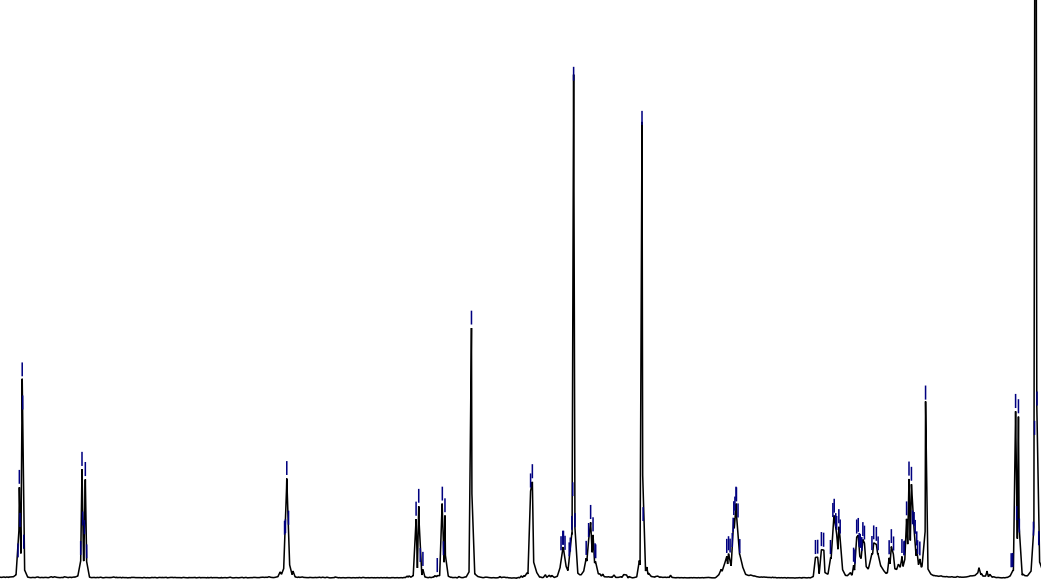




\begin{tabular}{|c|c|c|}
\hline & Parameter & Value \\
\hline 1 & Origin & Varian \\
\hline 2 & Spectrometer & vxrs \\
\hline 3 & Solvent & $\mathrm{cdcl} 3$ \\
\hline 4 & Temperature & 25.0 \\
\hline 5 & Experiment & $1 \mathrm{D}$ \\
\hline 6 & Number of Scans & 16 \\
\hline 7 & Relaxation Delay & 1.0000 \\
\hline 8 & Spectrometer Frequency & 399.74 \\
\hline 9 & Spectral Width & 5999.7 \\
\hline & Lowest Frequency & -1001.7 \\
\hline & 1 Nucleus & $1 \mathrm{H}$ \\
\hline & Acquired Size & 11999 \\
\hline & 3 Spectral Size & 65536 \\
\hline
\end{tabular}

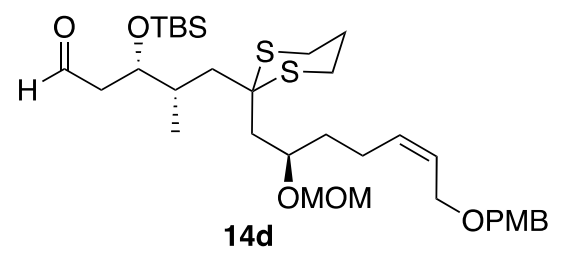

${ }^{1} \mathrm{H} \mathrm{NMR}\left(400 \mathrm{MHz}, \mathrm{CDCl}_{3}\right) \delta 9.80(\mathrm{t}, J=2.3 \mathrm{~Hz}, 1 \mathrm{H}), 7.38-7.10(\mathrm{~d}, 2 \mathrm{H}), 6.94-6.75$ $(\mathrm{d}, 2 \mathrm{H}), 5.60(\mathrm{td}, J=4.2,2.3 \mathrm{~Hz}, 2 \mathrm{H}), 4.78(\mathrm{~d}, J=6.8 \mathrm{~Hz}, 1 \mathrm{H}), 4.62(\mathrm{~d}, J=6.8 \mathrm{~Hz}$ $1 \mathrm{H}), 4.44(\mathrm{~s}, 2 \mathrm{H}), 4.20(\mathrm{ddd}, J=6.7,5.2,3.1 \mathrm{~Hz}, 1 \mathrm{H}), 4.11-4.02(\mathrm{~m}, 2 \mathrm{H}), 3.88(\mathrm{dd}, J$ $=5.8,4.0 \mathrm{~Hz}, 1 \mathrm{H}), 3.80(\mathrm{~s}, 3 \mathrm{H}), 3.37(\mathrm{~s}, 3 \mathrm{H}), 2.86-2.71(\mathrm{~m}, 5 \mathrm{H}), 2.63-2.44(\mathrm{~m}, 2 \mathrm{H})$, $2.28-2.11(\mathrm{~m}, 4 \mathrm{H}), 2.08-1.95(\mathrm{~m}, 2 \mathrm{H}), 1.91(\mathrm{q}, J=5.4 \mathrm{~Hz}, 2 \mathrm{H}), 1.83-1.59(\mathrm{~m}, 2 \mathrm{H})$,

$1.05(\mathrm{~d}, J=6.9 \mathrm{~Hz}, 3 \mathrm{H}), 0.88(\mathrm{~s}, 9 \mathrm{H}), 0.12(\mathrm{~s}, 3 \mathrm{H}), 0.05(\mathrm{~s}, 3 \mathrm{H})$

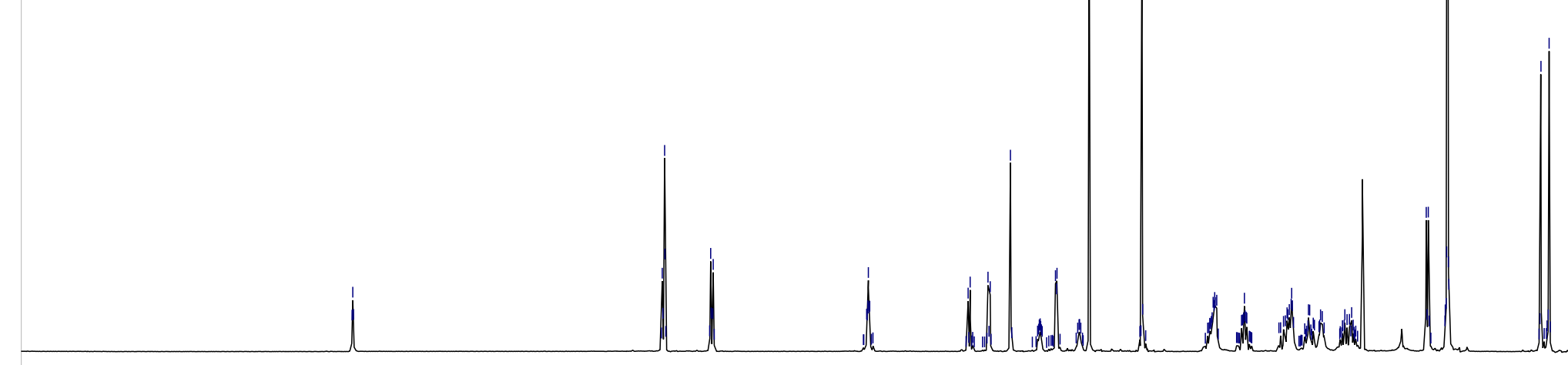

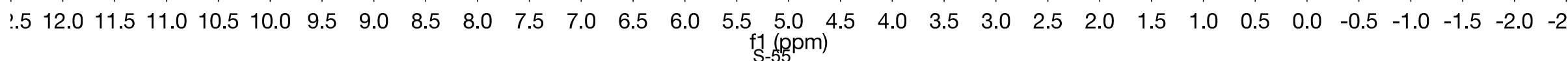




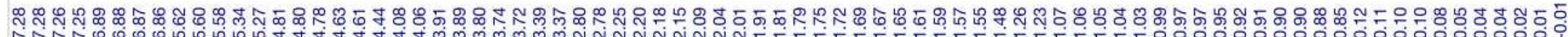

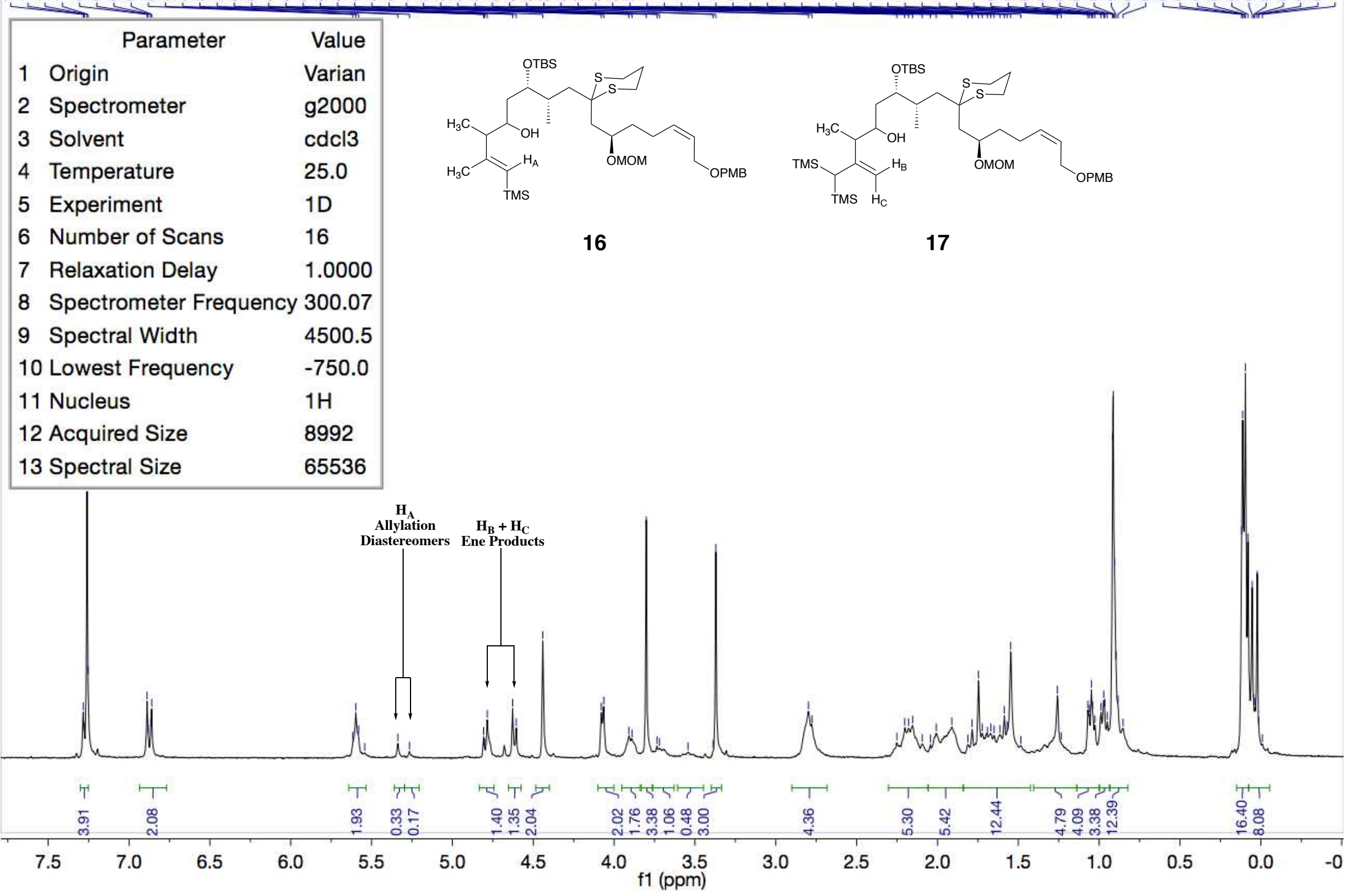




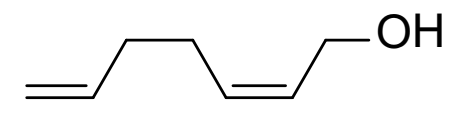

18

${ }^{1} \mathrm{H}$ NMR $\left(400 \mathrm{MHz}, \mathrm{CDCl}_{3}\right) \delta$ 5.88-5.75 (m, 1H), 5.64-5.51 (m, 2H), 5.05-4.96 (m, 2H), $4.21(\mathrm{~d}, J=5.7 \mathrm{~Hz}, 2 \mathrm{H})$ 2.19-2.11(m, 4H), $1.50(\mathrm{br}, \mathrm{s})$

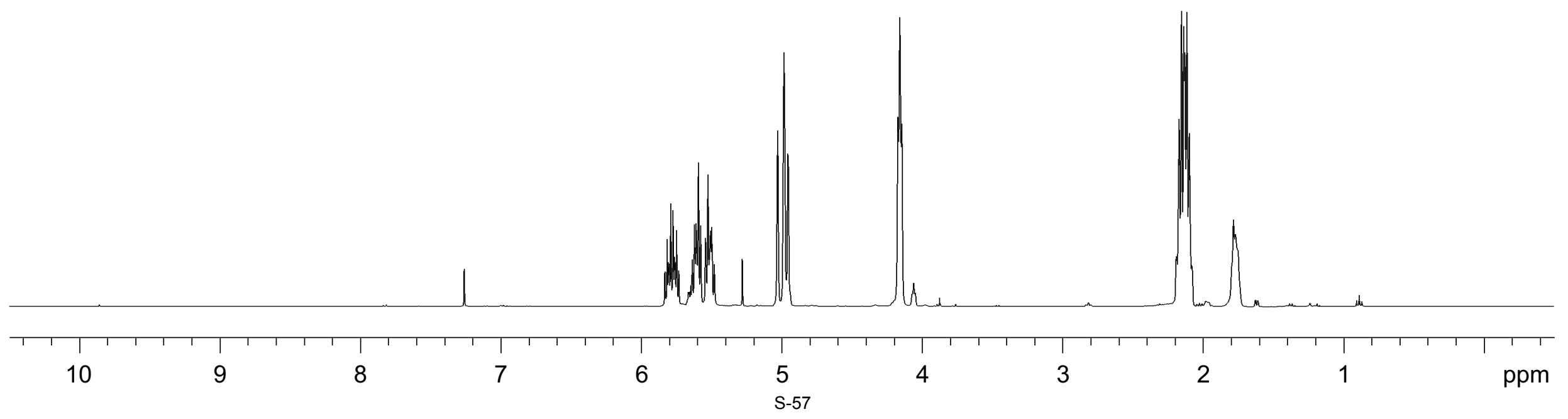




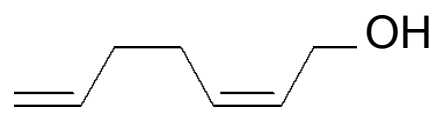

18

13C NMR (100 MHz, $\left.\mathrm{CDCl}_{3}\right)$ d 138.1, 132.2, 129.1, 115.3, 58.7, 33.8, 27.0

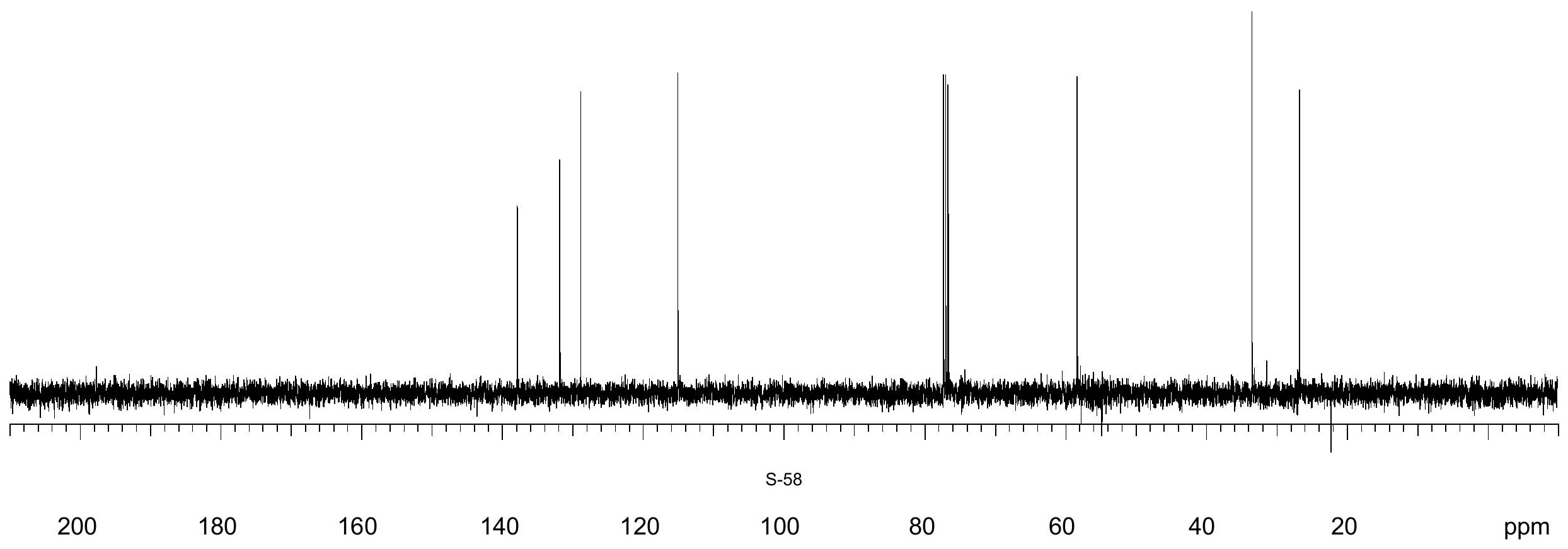




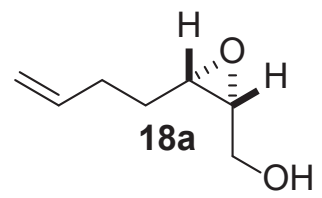

$\mathrm{OH}$
${ }^{1} \mathrm{H}$ NMR $\left(400 \mathrm{MHz}, \mathrm{CDCl}_{3}\right) \boldsymbol{\delta} 5.85-5.75(\mathrm{~m}, 1 \mathrm{H}), 5.04(\mathrm{~d}, J=17.2 \mathrm{~Hz}$, $1 \mathrm{H}), 4.97(\mathrm{~d}, J=17.2 \mathrm{~Hz}, 1 \mathrm{H}), 3.80\left(\mathrm{dd}, \mathrm{A}\right.$ of ABX, $J_{\mathrm{AB}}=12.2 \mathrm{~Hz}, J_{\mathrm{AX}}=$ $3.6 \mathrm{~Hz}, 1 \mathrm{H}), 3.63\left(\mathrm{dd}, \mathrm{B}\right.$ of $\left.\mathrm{AB}, J_{\mathrm{AB}}=12.2 \mathrm{~Hz}, J_{\mathrm{BX}}=6.8 \mathrm{~Hz}, 1 \mathrm{H}\right), 3.16$ $-3.12(\mathrm{~m}, 1 \mathrm{H}), 3.05-3.01(\mathrm{~m}, 1 \mathrm{H}), 2.27-2.13(\mathrm{~m}, 2 \mathrm{H}), 1.66-1.59(\mathrm{~m}, 2 \mathrm{H})$, $1.29-1.22(\mathrm{~m}, 1 \mathrm{H})$ 


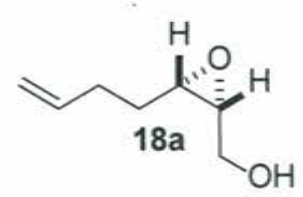

${ }^{13} \mathrm{C} \mathrm{NMR}\left(100 \mathrm{MHz}, \mathrm{CDCl}_{3}\right) \delta 137.5,115.6,60.9,57.2$,

$56.9,30.8,27.4$

1.6.

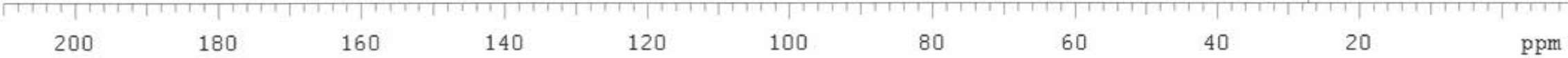




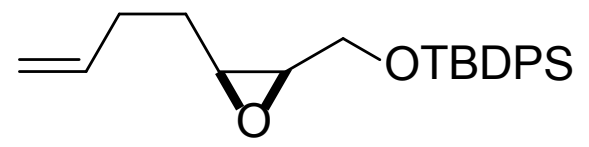

$18 b$
${ }^{1} \mathrm{H}$ NMR (400 MHz, $\left.\mathrm{CDCl}_{3}\right) \delta$ 7.72-7.68 (m, 4H), 7.47- 7.37 (m, 6H), 5.87-5.74 (m, $1 \mathrm{H}), 5.07-4.97(\mathrm{~m}, 2 \mathrm{H}), 3.85-3.73(\mathrm{dd}, J=8.1,5.4 \mathrm{~Hz}, 2 \mathrm{H}), 3.20-3.15(\mathrm{~m}, 1 \mathrm{H}), 3.01-$ $2.96(\mathrm{~m}, 1 \mathrm{H}), 2.27-2.14(\mathrm{~m}, 2 \mathrm{H}), 1.55-1.44(\mathrm{~m}, 2 \mathrm{H}), 1.08(\mathrm{~s}, 9 \mathrm{H})$

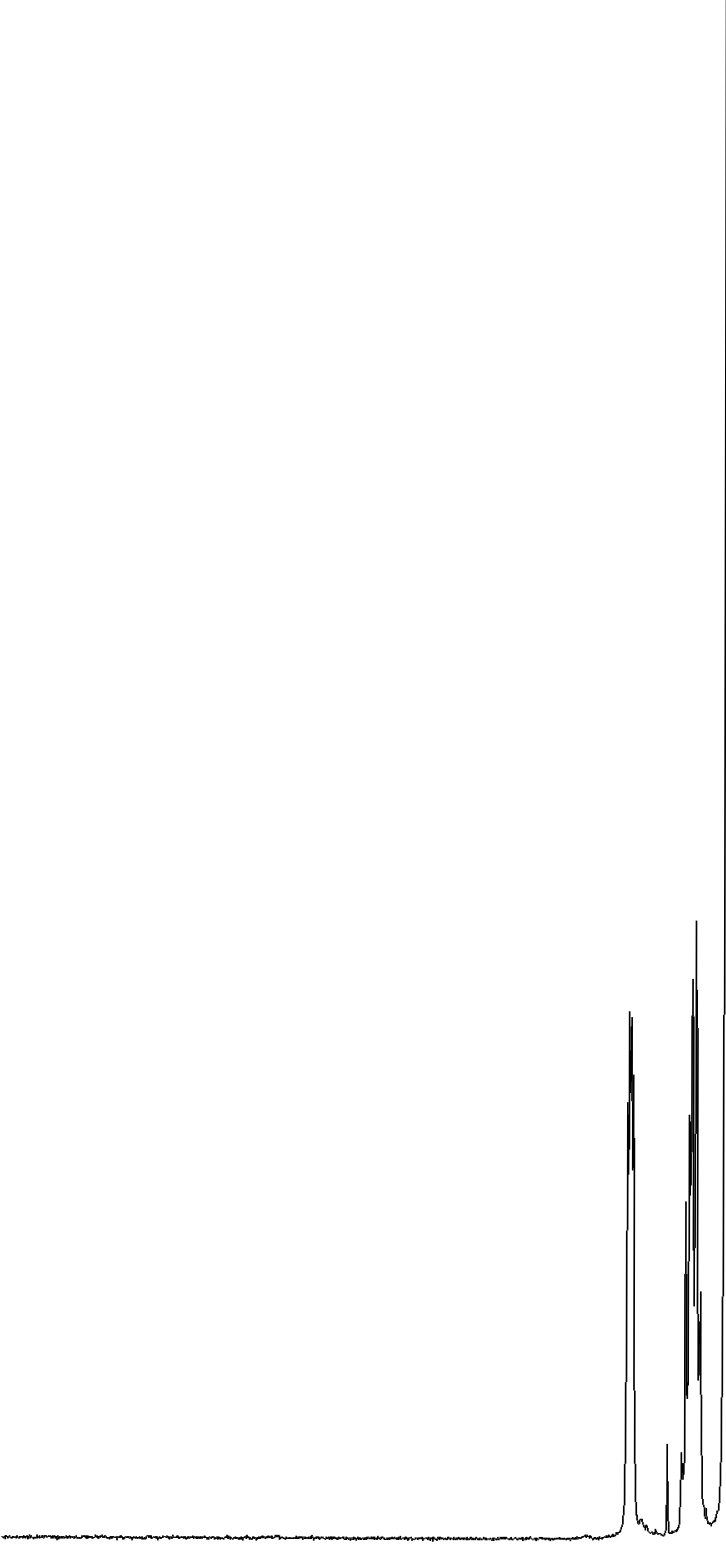




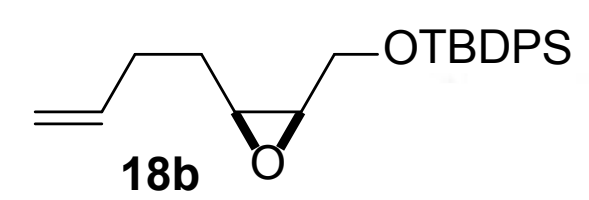

\section{${ }^{13} \mathrm{C}$ NMR $\left(100 \mathrm{MHz}, \mathrm{CDCl}_{3}\right) \delta 137.7$,} 135.8, 133.6, 133.4, 130.0, 127.9, $115.4,62.4,56.9,56.4,31.8,30.9$, 27.0, 19.4;

27.0, 19.4;

4

$\begin{array}{llllllllllll}220 & 200 & 180 & 160 & 140 & 120 & 100 & 80 & 60 & 40 & 20 & 0\end{array}$




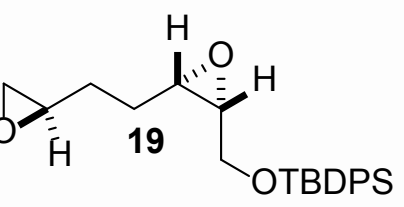

${ }^{1} \mathrm{H}$ NMR $\left(400 \mathrm{MHz}, \mathrm{CDCl}_{3}\right) \delta 7.68-7.67(\mathrm{~m}, 4 \mathrm{H}), 7.41-7.36(\mathrm{~m}, 6 \mathrm{H}), 3.83-3.72(\mathrm{~m}, 2 \mathrm{H}), 3.19-3.14(\mathrm{~m}, 1 \mathrm{H}), 2.99-2.95(\mathrm{~m}, 1 \mathrm{H})$, 2.88-2.84 (m, 1H), 2.72-2.69 (m, 1H), 2.44-2.42 (m, 1H), 1.76-1.69 (m, 1H), 1.64-1.54 (m, 2H), 1.51-1.49 (m, 1H), 1.05 (s, 9H);

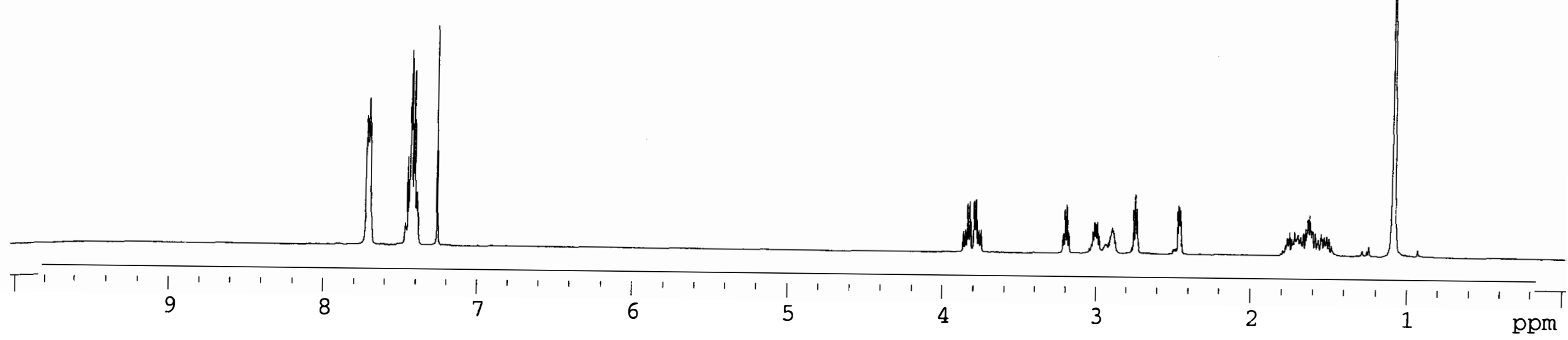




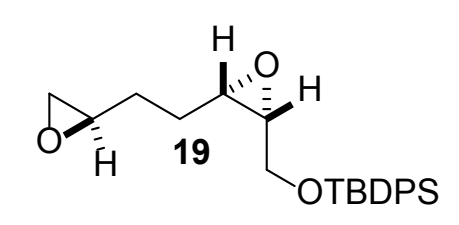
62.2, 60.5, 56.9, 56.4, 51.9, 47.2, 30.0, 26.9, 24.8, 19.4

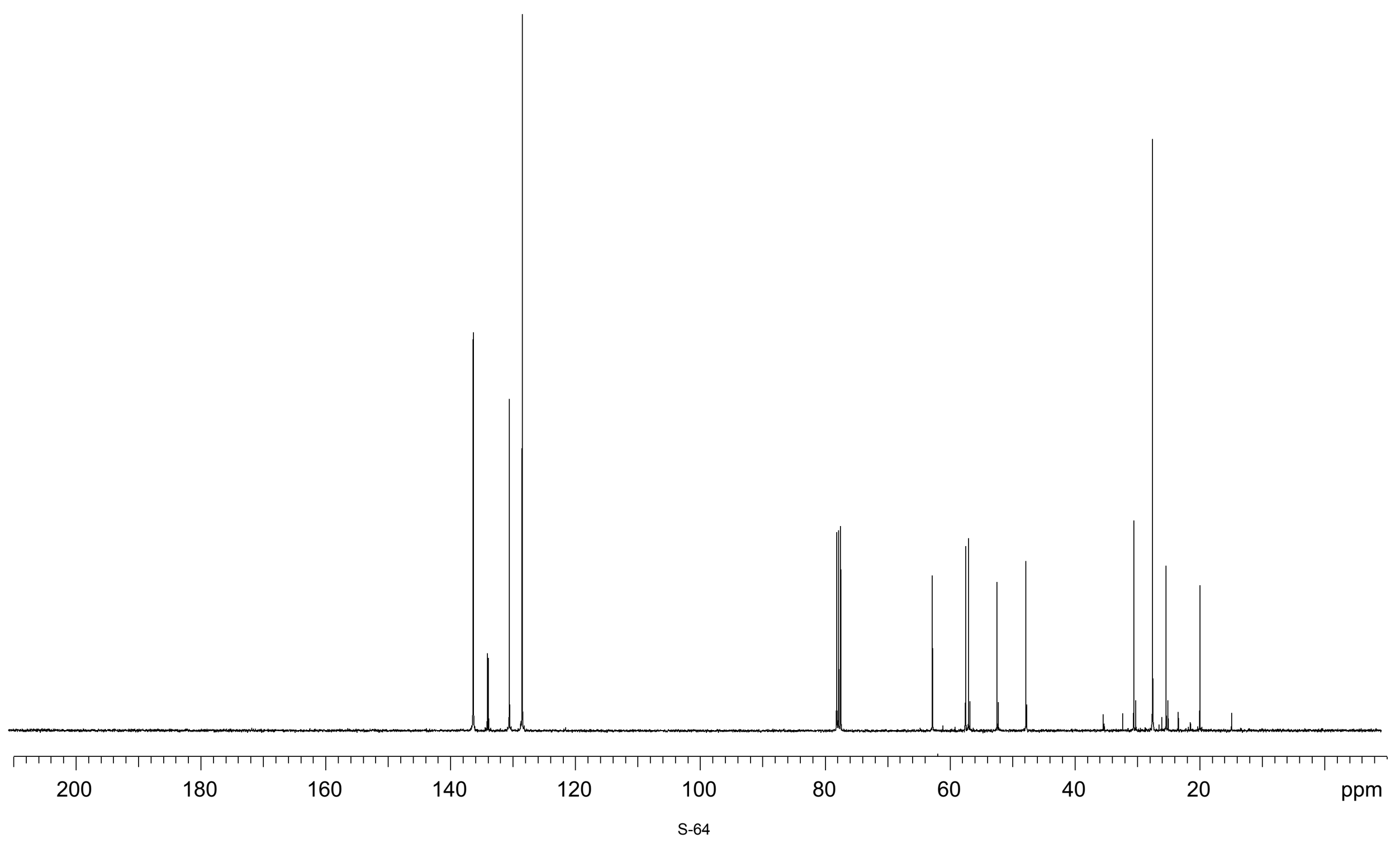




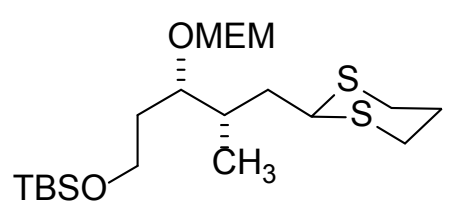

21

\section{[Scheme 6]}

${ }^{1} \mathrm{H}$ NMR $\left(400 \mathrm{MHz}, \mathrm{CDCl}_{3}\right) \delta 4.74(\mathrm{~s}, 2 \mathrm{H}), 4.13-4.09(\mathrm{~m}, 1 \mathrm{H}), 3.91-3.86(\mathrm{~m}, 1 \mathrm{H}), 3.81-3.73(\mathrm{~m}, 2 \mathrm{H}), 3.22(\mathrm{~s}$, $1 \mathrm{H}), 2.91-2.78(\mathrm{~m}, 4 \mathrm{H}), 2.11-2.08(\mathrm{~m}, 1 \mathrm{H}), 1.94-1.80(\mathrm{~m}, 3 \mathrm{H}), 1.73-1.51(\mathrm{~m}, 3 \mathrm{H}), 0.92(\mathrm{~d}, J=6.4 \mathrm{~Hz}, 3 \mathrm{H}), 0.88$

$(\mathrm{s}, 9 \mathrm{H}), 0.06(\mathrm{~s}, 6 \mathrm{H}), 0.03(\mathrm{~s}, 6 \mathrm{H})$

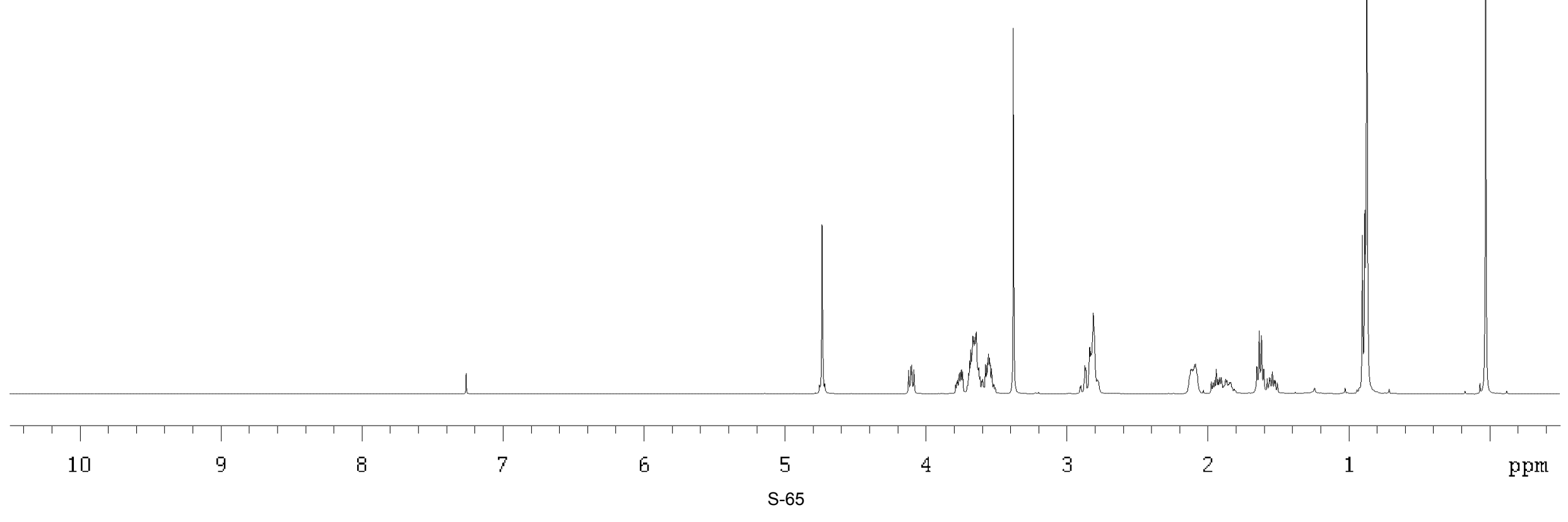




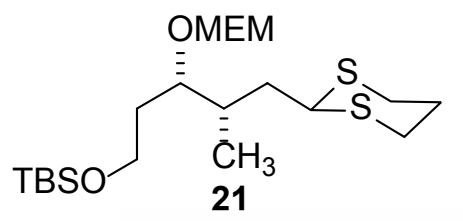

[Scheme 6]

${ }^{13} \mathrm{C}$ NMR $\left(100 \mathrm{MHz}, \mathrm{CDCl}_{3}\right) \boldsymbol{\delta} 94.9,77.5,71.6,67.0,59.7,58.8$

$45.3,37.5,33.8,32.5,30.2,30.0,26.0,25.8,18.0,14.6,-5.47,-5.53$

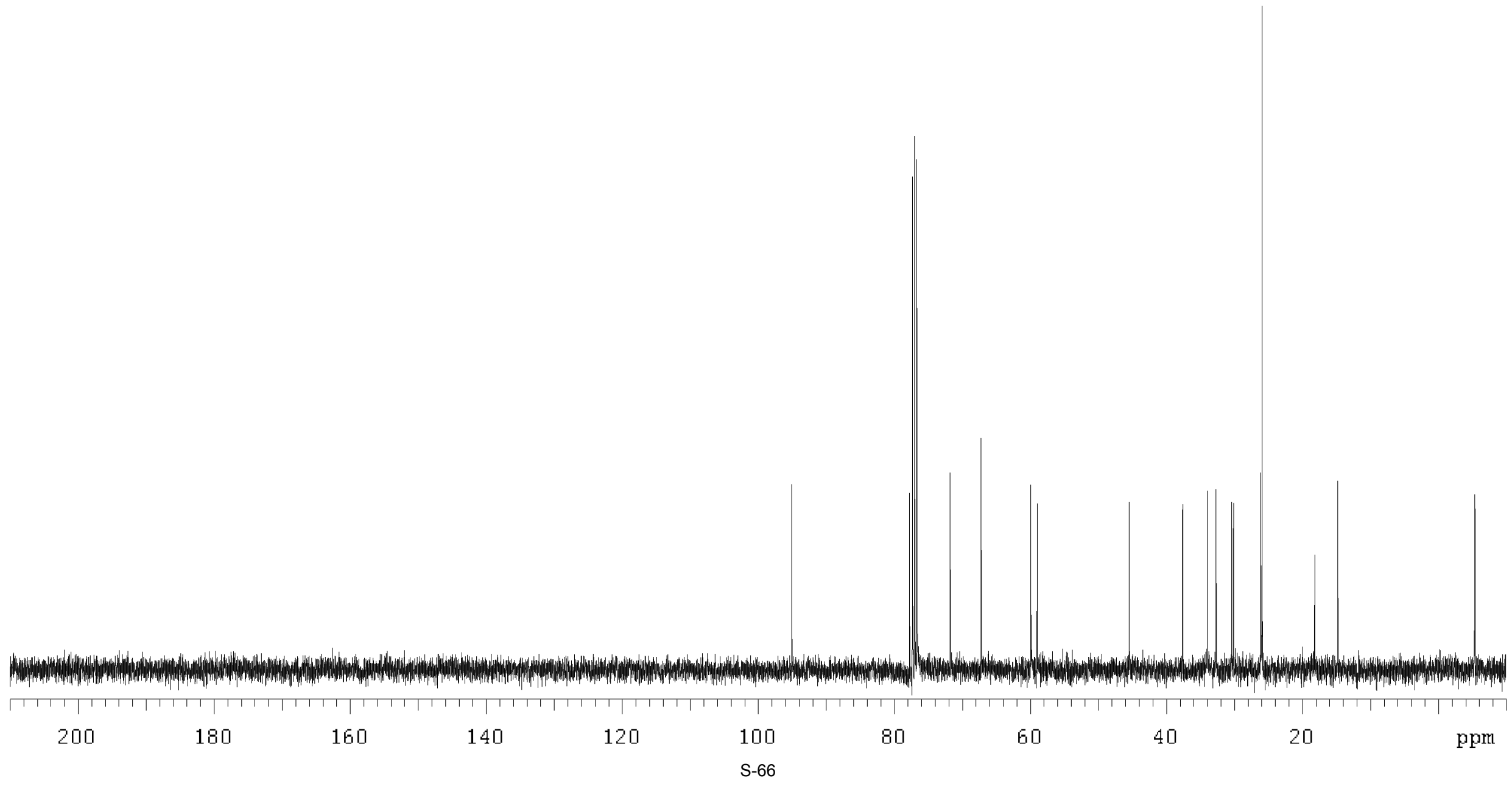




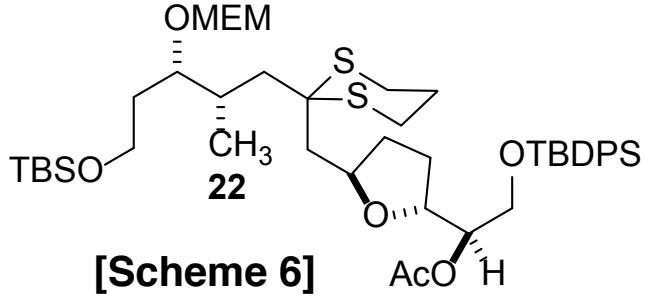

${ }^{1} \mathrm{H}$ NMR $\left(400 \mathrm{MHz}, \mathrm{CDCl}_{3}\right) \delta 7.67-7.64(\mathrm{~m}, 4 \mathrm{H}), 7.44-7.35(\mathrm{~m}, 6 \mathrm{H}), 4.95($ app. q, $J=5.4 \mathrm{~Hz}, 1 \mathrm{H}), 4.81(\mathrm{~d}, J=7.2 \mathrm{~Hz}, 1 \mathrm{H})$, $4.70(\mathrm{~d}, J=6.8 \mathrm{~Hz}, 1 \mathrm{H}), 4.22(\mathrm{app} . \mathrm{q}, J=5.1 \mathrm{~Hz}, 1 \mathrm{H}), 4.18-4.12(\mathrm{~m}, 1 \mathrm{H}), 3.78(\mathrm{~d}, J=4.8 \mathrm{~Hz}, 2 \mathrm{H}), 3.75-3.61(\mathrm{~m}, 4 \mathrm{H})$,

$3.55(\mathrm{t}, J=5.2 \mathrm{~Hz}, 2 \mathrm{H}), 3.38(\mathrm{~s}, 3 \mathrm{H}), 2.86-2.70(\mathrm{~m}, 4 \mathrm{H}), 2.35(\mathrm{dd}, J=14.8,2.4 \mathrm{~Hz}, 1 \mathrm{H}), 2.25(\mathrm{dd}, J=14.8,4.8 \mathrm{~Hz}, 1 \mathrm{H})$,

2.20-2.13 (m, 1H), 2.07-1.97 (m, 6H), $1.90($ app. $t, J=5.4 \mathrm{~Hz}, 2 \mathrm{H}), 1.68-1.51(\mathrm{~m}, 7 \mathrm{H}), 1.03(\mathrm{~s}, 3 \mathrm{H}), 1.00(\mathrm{~d}, J=7.2 \mathrm{~Hz}, 3 \mathrm{H})$,

$0.88(\mathrm{~s}, 9 \mathrm{H})$ 


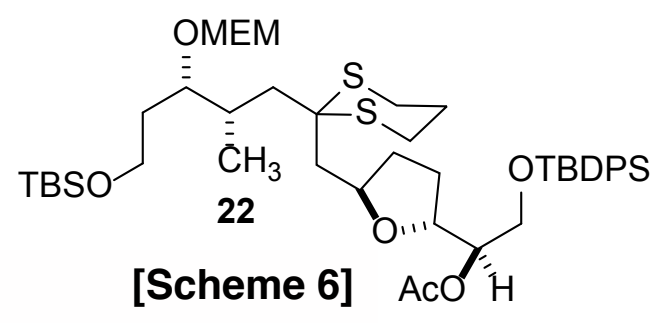

${ }^{13} \mathrm{C}$ NMR $\left(100 \mathrm{MHz}, \mathrm{CDCl}_{3}\right) \delta 170.6,135.6,135.5,133.3,129.7,127.68,127.65,94.5$, $79.1,76.2,76.0,75.9,71.8,67.2,63.2,60.3,59.0,45.0,41.1,34.3,34.1,32.2,28.3$, $26.7,26.2,26.1,25.9,25.0,21.2,19.2,18.2,17.6,-5.27,-5.33$

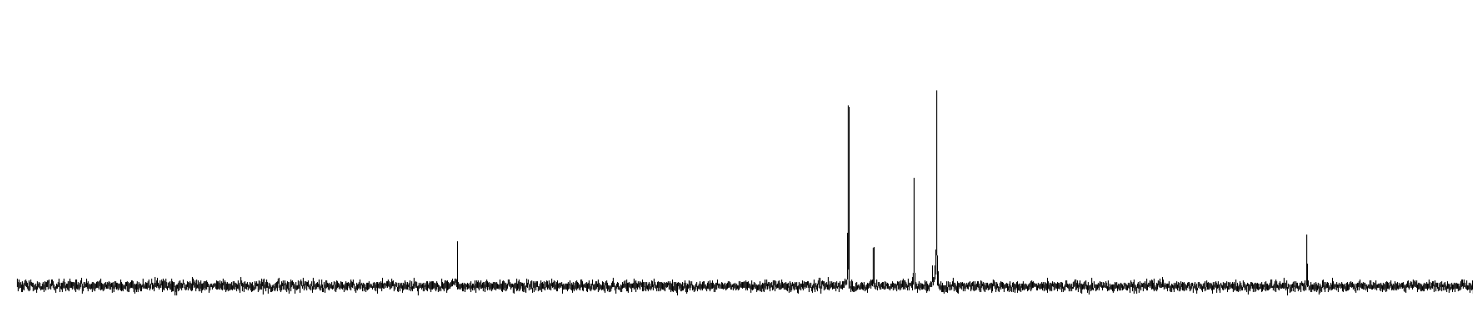

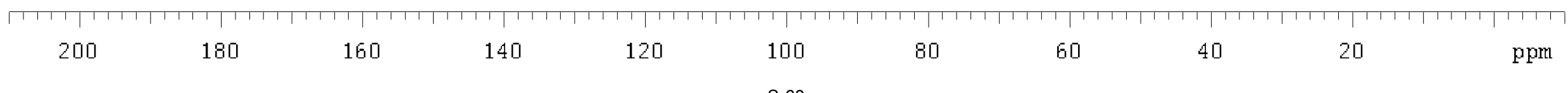




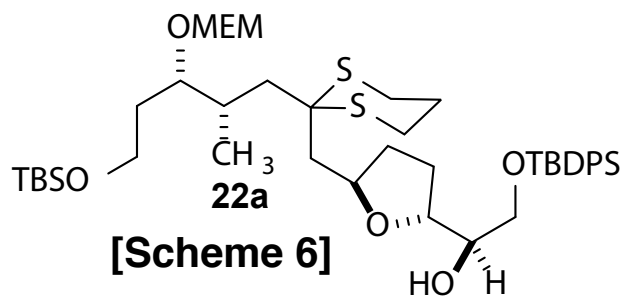

Intermediate alcohol of acetate $22(22 a)$

${ }^{1} \mathrm{H}$ NMR $\left(400 \mathrm{MHz}, \mathrm{CDCl}_{3}\right) \delta$ 7.69-7.64 (m, 4H), 7.43-7.34 (m, 6H), 4.80 (d, J=2.8 Hz, 1H), 4.70 (d, J=2.8 Hz, $1 \mathrm{H}), 4.20-4.13(\mathrm{~m}, 1 \mathrm{H}), 4.05$ (app. Q, $J=6.8 \mathrm{~Hz}, 2 \mathrm{H}), 3.76-3.60(\mathrm{~m}, 4 \mathrm{H}), 3.59-3.52(\mathrm{~m}, 3 \mathrm{H}), 3.34(\mathrm{~s}, 3 \mathrm{H}), 2.87-$ $2.71(\mathrm{~m}, 4 \mathrm{H}), 2.62(\mathrm{~d}, J=5.2 \mathrm{~Hz}, 1 \mathrm{H}), 2.37(\mathrm{dd}, J=14.8,2.0 \mathrm{~Hz}, 1 \mathrm{H}), 2.25(\mathrm{dd}, J=14.8,6.0 \mathrm{~Hz}, 1 \mathrm{H}), 2.15(\mathrm{~m}, 1 \mathrm{H})$, 2.07 (app. dd, $J=14.8,4.2 \mathrm{~Hz}, 3 \mathrm{H}), 1.99-1.86(\mathrm{~m}, 3 \mathrm{H}), 1.79-1.67$ (m, 2H), 1.67-1.51 (m, 4H), 1.05 (s, $9 \mathrm{H}), 1.01$ $(\mathrm{d}, J=6.8 \mathrm{~Hz}, 3 \mathrm{H}), 0.88(\mathrm{~s}, 9 \mathrm{H}), 0.04(\mathrm{~s}, 6 \mathrm{H})$ 


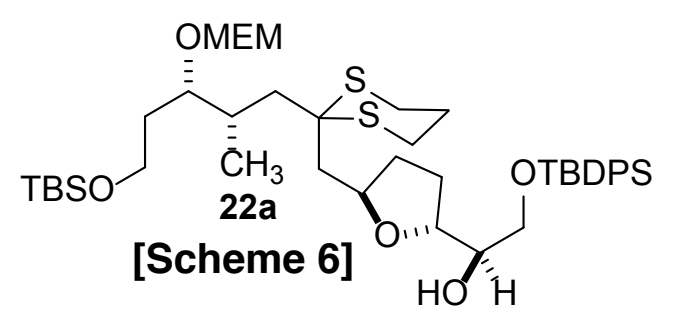

Intermediate alcohol of acetate 22 (22a)

${ }^{13} \mathrm{C} \mathrm{NMR}\left(100 \mathrm{MHz}, \mathrm{CDCl}_{3}\right) \delta 135.6,133.8,129.7,127.68,127.67,94.5,79.1,78.6,76.2,74.0$,

$71.8,67.2,65.4,60.3,59.0,53.3,45.1,41.7,34.26,34.21,32.3,28.3,26.8,26.3,25.9,25.0,19.2$,

$18.2,17.7,-5.26,-5.32$

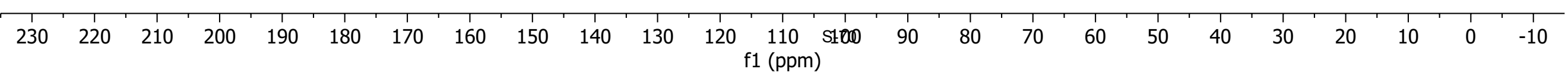




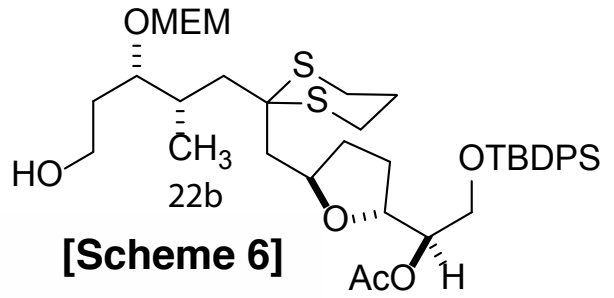

${ }^{1} \mathrm{H}$ NMR (400 MHz, CDCl 3$) \delta 7.67-7.63(\mathrm{~m}, 4 \mathrm{H}), 7.44-7.36(\mathrm{~m}, 6 \mathrm{H}), 4.96(\mathrm{dd}, J=10.8,5.2 \mathrm{~Hz}, 1 \mathrm{H}), 4.88(\mathrm{~d}, J=$ $7.2 \mathrm{~Hz}, 1 \mathrm{H}), 4.64(\mathrm{~d}, J=6.8 \mathrm{~Hz}, 1 \mathrm{H}), 4.22($ app. q, $J=6.4 \mathrm{~Hz}, 1 \mathrm{H}), 4.17-4.11(\mathrm{~m}, 1 \mathrm{H}), 3.89-3.85(\mathrm{~m}, 1 \mathrm{H}), 3.80-$ $3.73(\mathrm{~m}, 4 \mathrm{H}), 3.69-3.64(\mathrm{~m}, 1 \mathrm{H}), 3.62-3.52(\mathrm{~m}, 3 \mathrm{H}), 3.39(\mathrm{~s}, 3 \mathrm{H}), 2.87(\mathrm{t}, J=6.2 \mathrm{~Hz}, 1 \mathrm{H}), 2.78(\mathrm{t}, J=5.4 \mathrm{~Hz}, 4 \mathrm{H})$, $2.31(\mathrm{~d}, J=14.8 \mathrm{~Hz}, 2 \mathrm{H}), 2.25-1.96(\mathrm{~m}, 6 \mathrm{H}), 1.90$ (app. q, $J=5.4 \mathrm{~Hz}, 2 \mathrm{H}), 1.72-1.49(\mathrm{~m}, 4 \mathrm{H}), 1.03(\mathrm{~s}, 9 \mathrm{H}), 1.00(\mathrm{~d}$ $J=7.2 \mathrm{~Hz}, 3 \mathrm{H})$ 


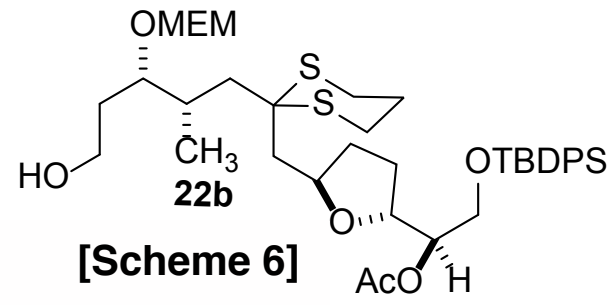

${ }^{13} \mathrm{C}$ NMR $\left(100 \mathrm{MHz}, \mathrm{CDCl}_{3}\right) \delta$ 170.6,135.6, 135.5, 133.3, 133.2, 129.69, 127.68, 127.65, 93.8, 78.5, $76.3,76.1,75.9,71.8,67.3,63.2,59.3,59.0,53.2,45.1,40.3,34.1,32.3,31.3,28.2,26.7,26.2,26.1$ $25.0,21.2,19.2,18.4$

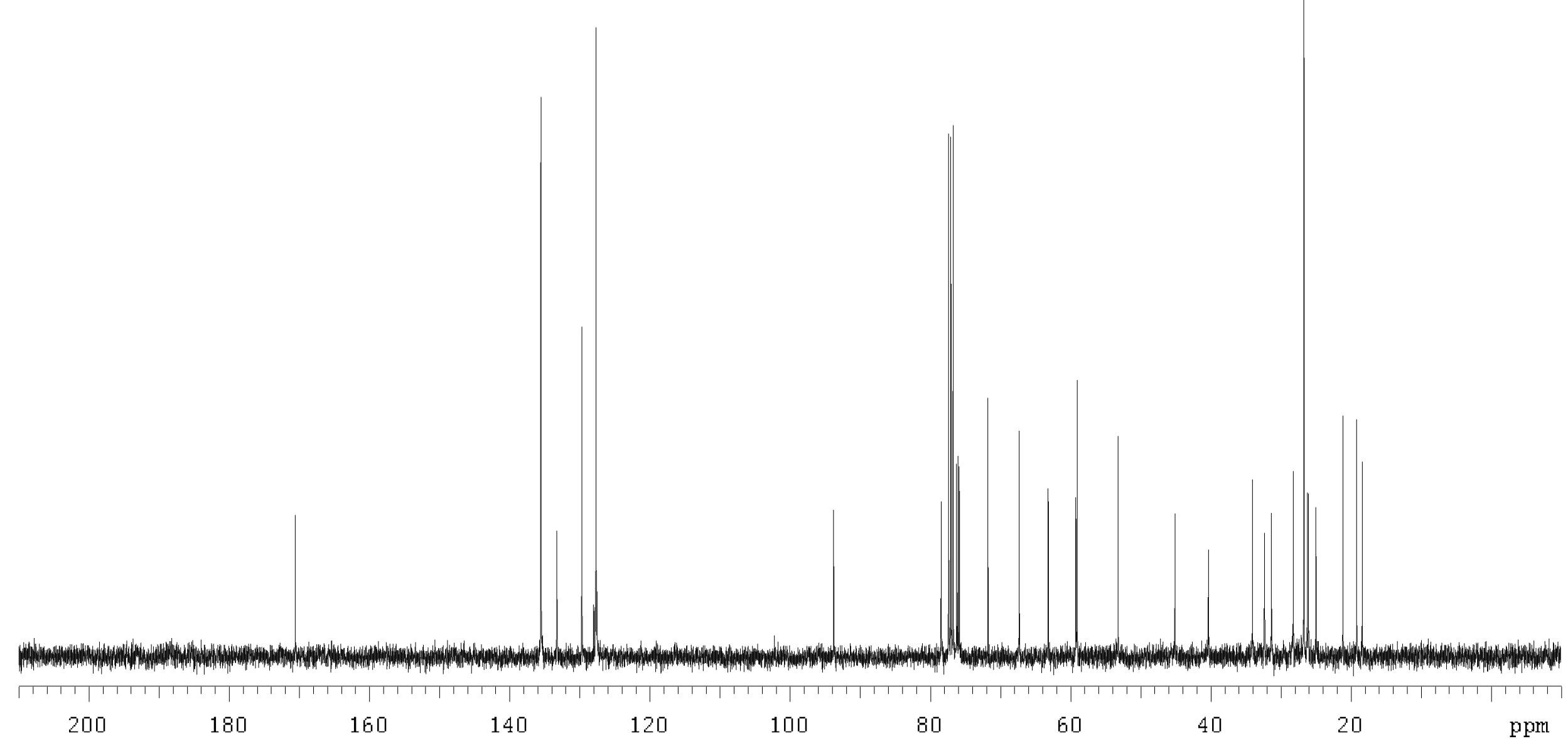



造

\begin{tabular}{|c|c|c|c|}
\hline 1 & $\begin{array}{l}\text { Parameter } \\
\text { Origin }\end{array}$ & $\begin{array}{l}\text { Value } \\
\text { Varian }\end{array}$ & OMEM \\
\hline 2 & Spectrometer & inova & \\
\hline 3 & Solvent & cdcl3 & \\
\hline 4 & Temperature & 25.0 & \\
\hline 5 & Experiment & $1 \mathrm{D}$ & \\
\hline 6 & Number of Scans & 8 & [Scheme 6] \\
\hline 7 & Relaxation Delay & 1.0000 & ${ }^{1} \mathrm{H} \mathrm{NMR}\left(400 \mathrm{MHz}, \mathrm{CDCl}_{3}\right) \delta 9.73(\mathrm{dd}, J=3.1,1.6 \mathrm{~Hz}$ \\
\hline 8 & Spectrometer Frequency & 399.93 & $1 \mathrm{H}), 7.63(\mathrm{ddd}, J=7.9,4.9,1.6 \mathrm{~Hz}, 4 \mathrm{H}), 7.37$ (dddd, $J=$ \\
\hline 9 & Spectral Width & 6399.0 & $(\mathrm{~d}, J=7.3 \mathrm{~Hz}, 1 \mathrm{H}), 4.65(\mathrm{~d}, J=7.3 \mathrm{~Hz}, 1 \mathrm{H}), 4.27-4.03$ \\
\hline 10 & Lowest Frequency & -800.0 & $(\mathrm{~m}, 3 \mathrm{H}), 3.75(\mathrm{~d}, J=5.1 \mathrm{~Hz}, 2 \mathrm{H}), 3.69(\mathrm{dt}, J=10.4,4.3$ \\
\hline 11 & Nucleus & $1 \mathrm{H}$ & $\begin{array}{l}\mathrm{Hz}, 1 \mathrm{H}), 3.61-3.52(\mathrm{~m}, 1 \mathrm{H}), 3.51(\mathrm{dd}, J=5.1,3.8 \mathrm{~Hz}, 2 \mathrm{H}) \\
3.35(\mathrm{~s}, 3 \mathrm{H}), 2.76(\mathrm{dt}, J=7.0,4.2 \mathrm{~Hz}, 4 \mathrm{H}), 2.58(\mathrm{ddd}, J=\end{array}$ \\
\hline 12 & Acquired Size & 16384 & $16.2,8.7,3.1 \mathrm{~Hz}, 1 \mathrm{H}), 2.44-2.22(\mathrm{~m}, 2 \mathrm{H}), 2.22-2.06(\mathrm{~m}$, \\
\hline & Spectral Size & 65536 & $\begin{array}{l}4 \mathrm{H}), 2.04(\mathrm{~s}, 3 \mathrm{H}), 2.01-1.79(\mathrm{~m}, 2 \mathrm{H}), 1.69-1.43(\mathrm{~m}, 4 \mathrm{H}) \\
1.01(\mathrm{~s}, 9 \mathrm{H}), 0.98(\mathrm{~d}, J=6.9 \mathrm{~Hz}, 3 \mathrm{H})\end{array}$ \\
\hline
\end{tabular}

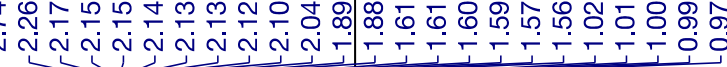

1 Origin

2 Spectrometer

3 Solvent

4 Temperature

5 Experiment

23

\section{[Scheme 6]}

$1 \mathrm{H}$ ), 7.63 (ddd, $J=7.9,4.9,1.6 \mathrm{~Hz}, 4 \mathrm{H}$ ), 7.37 (dddd, $J=$

.

$(\mathrm{m}, 3 \mathrm{H}), 3.75(\mathrm{~d}, J=5.1 \mathrm{~Hz}, 2 \mathrm{H}), 3.69(\mathrm{dt}, J=10.4,4.3$

Hz, 1H), 3.61-3.52 (m, 1H), $3.51(\mathrm{dd}, J=5.1,3.8 \mathrm{~Hz}, 2 \mathrm{H})$,

$.35(\mathrm{~s}, 3 \mathrm{H}), 2.76(\mathrm{dt}, J=7.0,4.2 \mathrm{~Hz}, 4 \mathrm{H}), 2.58(\mathrm{ddd}, J=$

$4 \mathrm{H}), 2.04(\mathrm{~s}, 3 \mathrm{H}), 2.01-1.79(\mathrm{~m}, 2 \mathrm{H}), 1.69-1.43(\mathrm{~m}, 4 \mathrm{H})$,

$1.01(\mathrm{~s}, 9 \mathrm{H}), 0.98(\mathrm{~d}, J=6.9 \mathrm{~Hz}, 3 \mathrm{H})$

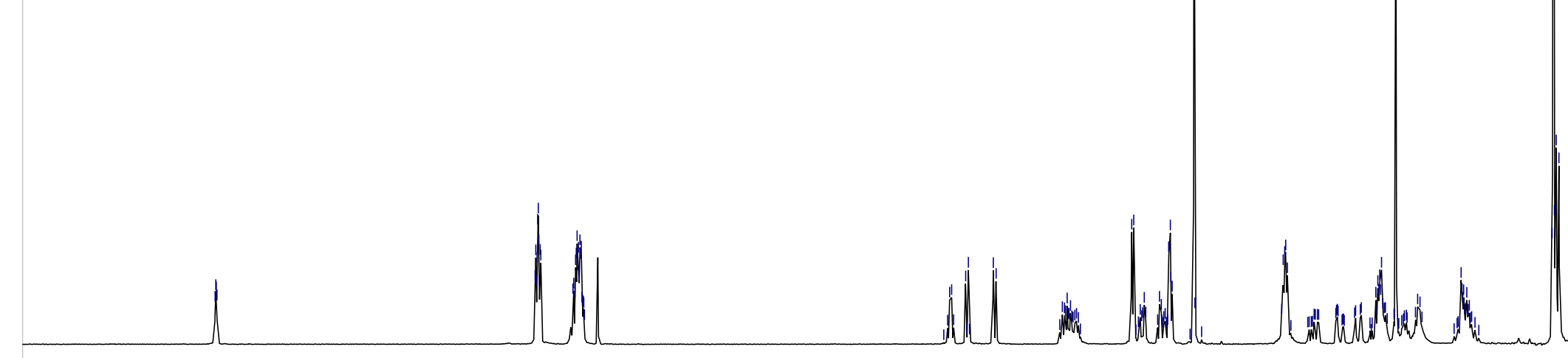

10.5

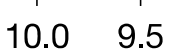

9.0

8.5

8.0

$\begin{array}{ll}7.5 & 7.0\end{array}$

6.5

$6.0 \quad 5.5-73 \begin{gathered}5.0 \\ f 1\end{gathered}$

$4.5 \quad 4.0$

3.5

2.5

2.0

$1.5 \quad 1.0$

0.5 


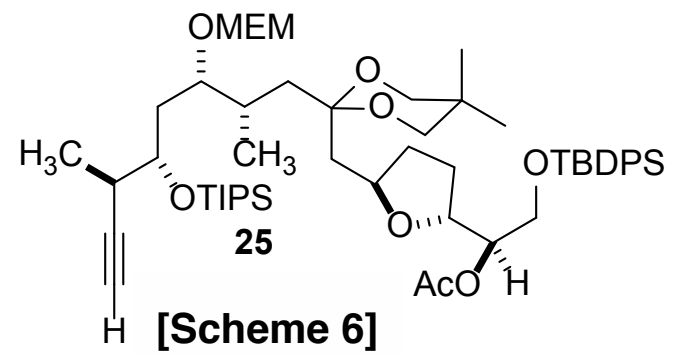

${ }^{1} \mathrm{H}$ NMR $(400 \mathrm{MHz}, \mathrm{C} 6 \mathrm{D} 6) \delta 7.83-7.80(\mathrm{~m}, 2 \mathrm{H}), 7.80-7.75(\mathrm{~m}, 2 \mathrm{H}), 7.25-7.21(\mathrm{~m}, 6 \mathrm{H}), 5.22(\mathrm{dd}, J=10.2,5.8 \mathrm{~Hz}$, $1 \mathrm{H}), 4.93(\mathrm{~d}, J=6.8 \mathrm{~Hz}, 1 \mathrm{H}), 4.88(\mathrm{~d}, J=6.8 \mathrm{~Hz}, 1 \mathrm{H}), 4.31-4.22(\mathrm{~m}, 2 \mathrm{H}), 4.18(\mathrm{dd}, J=12.4,6.8 \mathrm{~Hz}, 1 \mathrm{H}), 3.95-$ $3.86(\mathrm{~m}, 3 \mathrm{H}), 3.78$ (app. t, $J=5.2 \mathrm{~Hz}, 2 \mathrm{H}), 3.46-3.29(\mathrm{~m}, 6 \mathrm{H}), 3.14(\mathrm{~s}, 3 \mathrm{H}), 2.96-2.88(\mathrm{~m}, 1 \mathrm{H}), 2.39-2.23(\mathrm{~m}, 4 \mathrm{H})$ $2.01-1.90(\mathrm{~m}, 3 \mathrm{H}), 1.90(\mathrm{~d}, J=2.8 \mathrm{~Hz}, 1 \mathrm{H}), 1.86(\mathrm{~s}, 3 \mathrm{H}), 1.80(\mathrm{dd}, J=14.4,7.2 \mathrm{~Hz}, 1 \mathrm{H}), 1.73-1.63(\mathrm{~m}, 1 \mathrm{H}), 1.47-$ $1.37(\mathrm{~m}, 2 \mathrm{H}), 1.33(\mathrm{~d}, J=7.2 \mathrm{~Hz}, 3 \mathrm{H}), 1.28(\mathrm{~d}, J=6.8 \mathrm{~Hz}, 3 \mathrm{H}), 1.18-1.11(\mathrm{~m}, 30 \mathrm{H}), 0.87(\mathrm{~s}, 3 \mathrm{H}), 0.63(\mathrm{~s}, 3 \mathrm{H})$

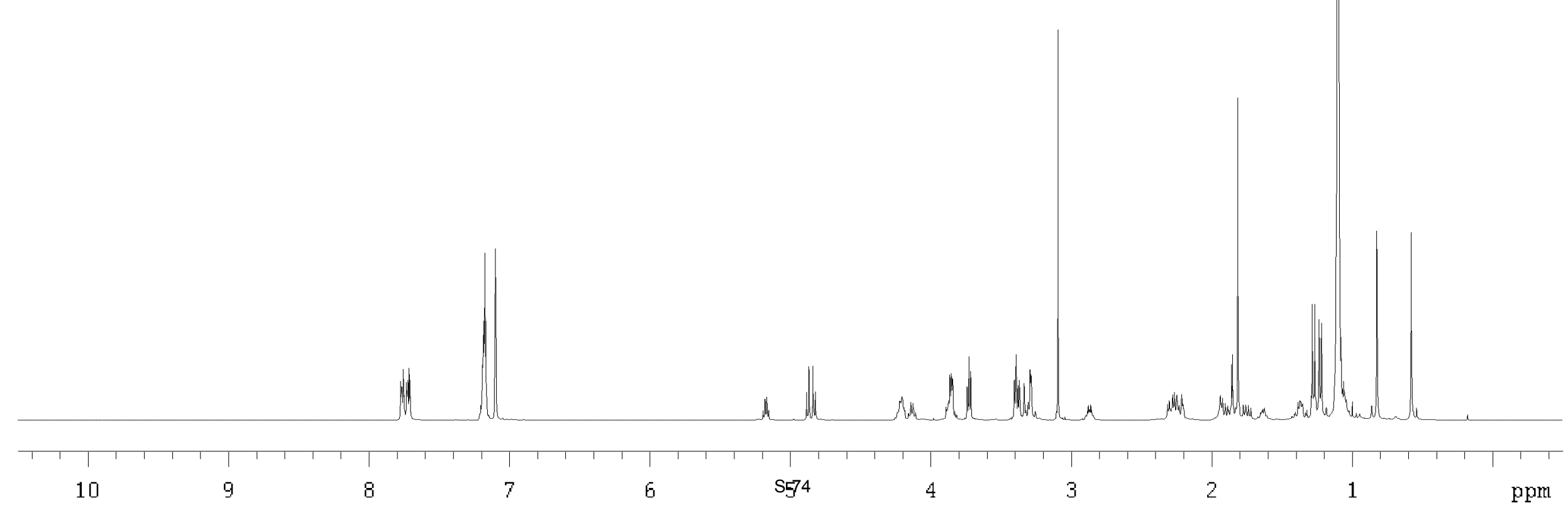




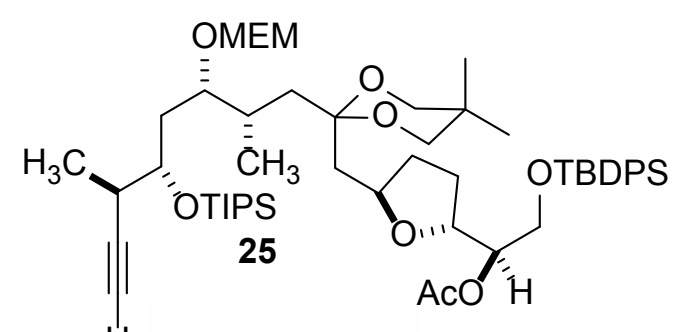

[Scheme 6]
${ }^{13} \mathrm{C}$ NMR $\left(100 \mathrm{MHz}, \mathrm{C}_{6} \mathrm{D}_{6}\right) \delta 169.9,136.0,135.9,133.81,133.78,130.04,130.00,128.11,128.10$, (127.997 benzene reference), 100.4, 95.5, 85.8, 80.3, 76.5, 76.1, 76.0, 73.1, 72.3, 70.7, 70.2, 70.1, $67.9,63.9,58.7,39.5,38.5,36.9,34.0,32.9,32.0,29.5,28.5,27.0,23.1,22.6,20.9,19.4,18.5,16.6$, 15.9, 13.4;

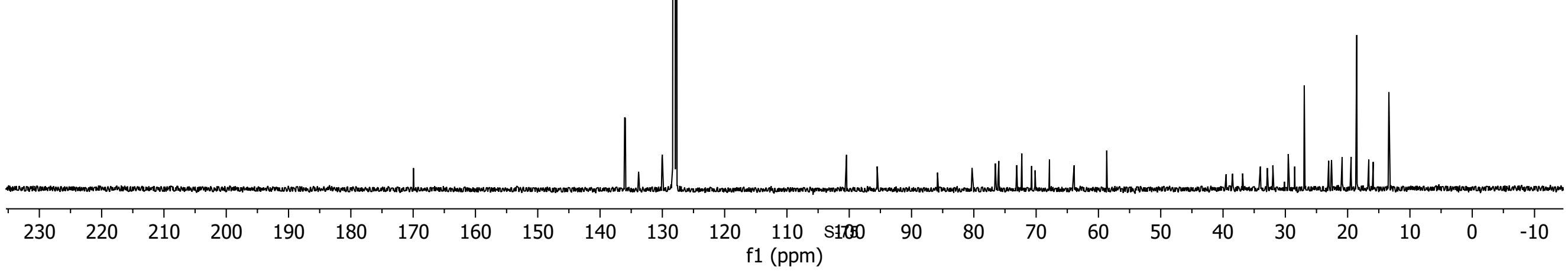




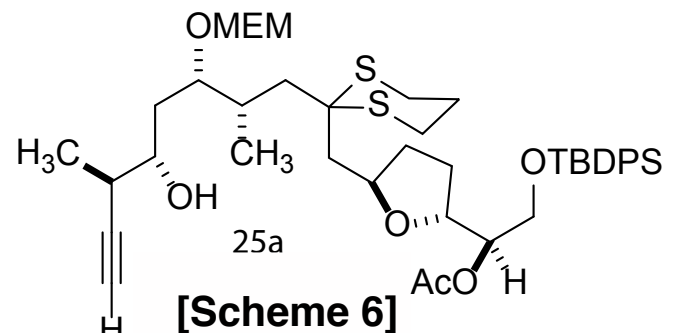

Intermediate alcohol (25a) leading to 25

${ }^{1} \mathrm{H} \mathrm{NMR}\left(400 \mathrm{MHz}, \mathrm{CDCl}_{3}\right) \delta 7.67-7.63(\mathrm{~m}, 4 \mathrm{H}), 7.42-7.34$ (m, 6H), 4.95 (app. q, $\left.J=5.2 \mathrm{~Hz}, 1 \mathrm{H}\right), 4.86$ (d, $J=7.0$ $\mathrm{Hz}, 1 \mathrm{H}), 4.62(\mathrm{~d}, J=7.0 \mathrm{~Hz}, 1 \mathrm{H}), 4.26-4.18(\mathrm{~m}, 1 \mathrm{H}), 4.18-4.08(\mathrm{~m}, 1 \mathrm{H}), 3.91-3.83(\mathrm{~m}, 1 \mathrm{H}), 3.77$ (app. d, $J=5.2$ $\mathrm{Hz}, 2 \mathrm{H}), 3.76-3.68(\mathrm{~m}, 1 \mathrm{H}), 3.63-3.50(\mathrm{~m}, 3 \mathrm{H}), 3.39(\mathrm{~s}, 4 \mathrm{H}), 2.84-2.70(\mathrm{~m}, 4 \mathrm{H}), 2.54-2.47$ (m, 1H), 2.31 (app. d, $J$ $=13.6,1 \mathrm{H}), 2.25(\mathrm{dd}, J=14.8,4.8 \mathrm{~Hz}, 1 \mathrm{H}), 2.15-2.13(\mathrm{~m}, 2 \mathrm{H}), 2.08(\mathrm{~d}, J=2.8 \mathrm{~Hz}, 1 \mathrm{H}), 2.05(\mathrm{~s}, 3 \mathrm{H}), 2.05-1.95(\mathrm{~m}$ $2 \mathrm{H}), 1.95-1.85(\mathrm{~m}, 2 \mathrm{H}), 1.77-1.45(\mathrm{~m}, 6 \mathrm{H}), 1.24(\mathrm{~d}, J=2.8 \mathrm{~Hz}, 3 \mathrm{H}), 1.02(\mathrm{~s}, 12 \mathrm{H})$ 


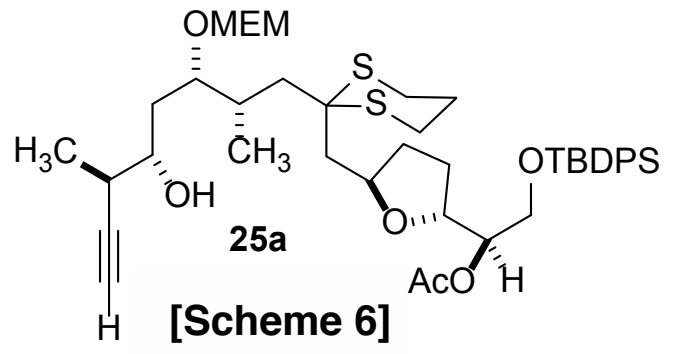

Intermediate alcohol (25a) leading to $\mathbf{2 5}$

${ }^{13} \mathrm{C}$ NMR $(100 \mathrm{MHz}, \mathrm{CDCl} 3) \delta 170.5,135.6,135.5,133.3,133.2,129.7,129.6,127.64,127.62$, $93.8,85.9,78.2,71.8,70.2,69.2,67.3,63.1,59.0,53.1,59.0,53.1,45.0,40.2,34.9,34.0,32.9$, $31.7,28.3,26.7,26.2,26.0,24.9,24.1,19.2,18.6,17$

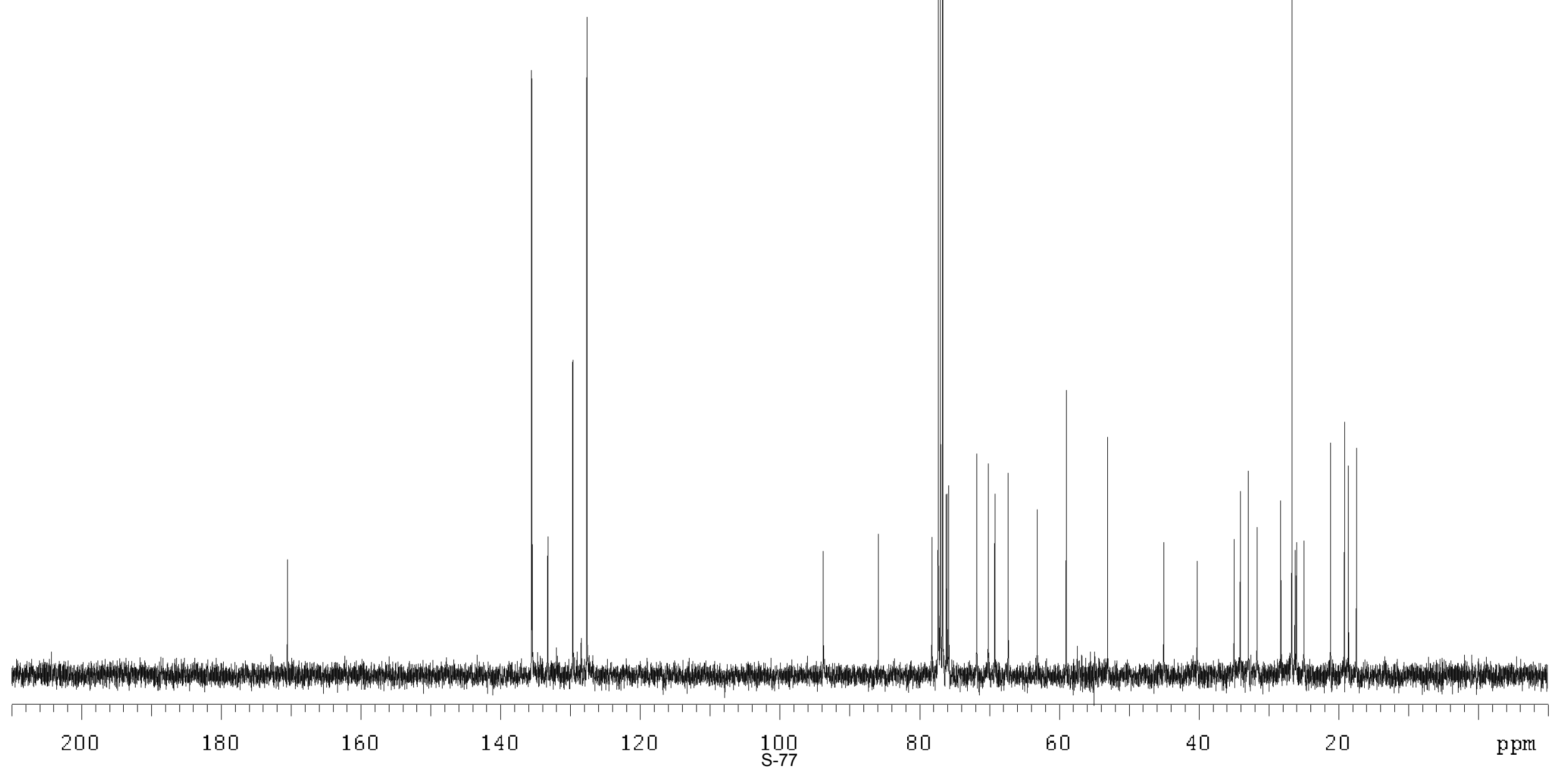




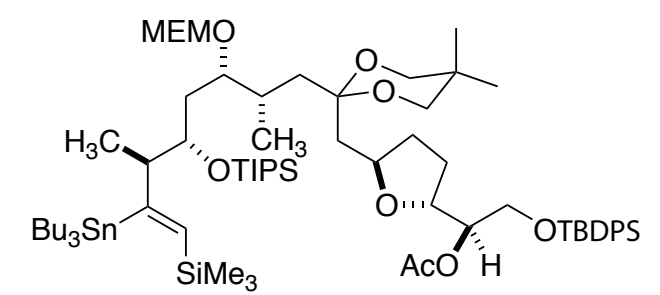

${ }^{1} \mathrm{H}$ NMR $\left(400 \mathrm{MHz}, \mathrm{CDCl}_{3}\right) \delta 7.69-7.64(\mathrm{~m}, 4 \mathrm{H}), 7.49-7.35(\mathrm{~m}, 6 \mathrm{H}), 6.60(\mathrm{~s}, 1 \mathrm{H})$ [117Sn and 119Sn observed], $4.97(\mathrm{dd}, J=10.6,5.0 \mathrm{~Hz}, 1 \mathrm{H}), 4.80(\mathrm{~d}, J=6.8 \mathrm{~Hz}, 1 \mathrm{H}), 4.74(\mathrm{~d}, J=6.8 \mathrm{~Hz}, 1 \mathrm{H}), 4.27-4.19(\mathrm{~m}, 2 \mathrm{H}), 4.19-4.10(\mathrm{~m}$, $1 \mathrm{H}), 3.80$ (app. d, $J=5.2 \mathrm{~Hz}, 2 \mathrm{H}), 3.78-3.62(\mathrm{~m}, 3 \mathrm{H}), 3.60-3.40(\mathrm{~m}, 6 \mathrm{H}), 3.38$ (s, $3 \mathrm{H}), 2.57$ (dd, $J=13.4,6.2 \mathrm{~Hz}$, $1 \mathrm{H}), 2.18-2.10(\mathrm{~m}, 3 \mathrm{H}), 2.07(\mathrm{~s}, 3 \mathrm{H}), 2.04-1.89(\mathrm{~m}, 2 \mathrm{H}), 1.83(\mathrm{dd}, J=14.2,7.4 \mathrm{~Hz}, 1 \mathrm{H}), 1.68-1.42(\mathrm{~m}, 10 \mathrm{H})$ $1.40-1.24$ (m, 6H), 1.07 (s, 21H), 1.04 (s, 9H), 1.02-0.88 (m, 28H), 0.09 (s, 9H) 


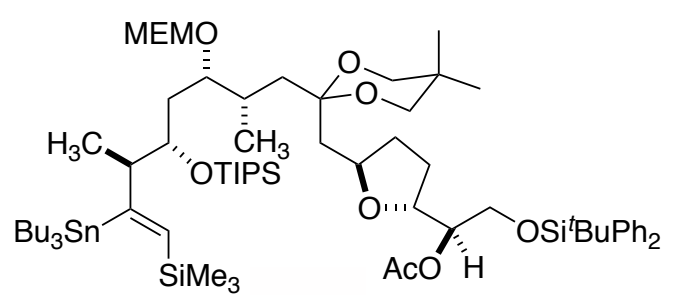

26a

[Scheme 6]

${ }^{13} \mathrm{C} \mathrm{NMR}(100 \mathrm{MHz}, \mathrm{CDCl} 3) \delta 170.6,168.1,141.9,135.6,135.5,133.4,133.3$,

129.7, 127.7, 127.6, 99.8, 95.3, 81.5, 76.2, 76.1, 75.8, 72.8, 71.8, 70.0, 69.9, 67.6,

$63.3,59.0,50.5,40.1,35.3,34.8,33.5,31.2,29.6,29.2,28.5,27.6,26.7,22.8,21.2$

$19.2,18.4,17.2,15.0,13.6,13.1,11.5,0.3$

(1) 


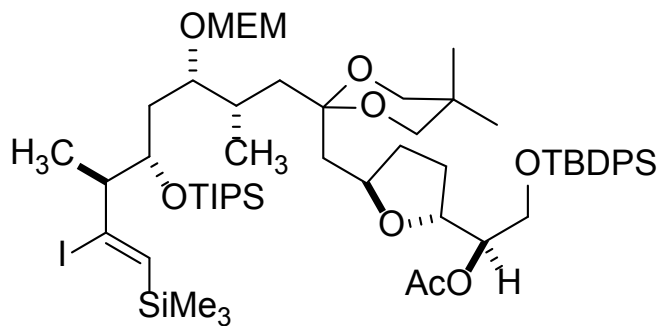

26

\section{[Scheme 6]}

${ }^{1} \mathrm{H}$ NMR (400 MHz, CDCl ): $\delta 7.70-7.64(\mathrm{~m}, 4 \mathrm{H}), 7.45-7.32(\mathrm{~m}, 6 \mathrm{H}), 6.63$ (s, 1H), 4.97 (app. q, $J=5.2 \mathrm{~Hz}, 1 \mathrm{H}$ ), $4.81(\mathrm{~d}, J=6.4 \mathrm{~Hz}, 1 \mathrm{H}), 4.77(\mathrm{~d}, J=6.4 \mathrm{~Hz}, 1 \mathrm{H}), 4.30-4.20(\mathrm{~m}, 2 \mathrm{H}), 4.17-4.10(\mathrm{~m}, 1 \mathrm{H}), 3.81$ (app. d, $J=4.8 \mathrm{~Hz}$, $2 \mathrm{H}), 3.80-3.71(\mathrm{~m}, 2 \mathrm{H}), 3.67-3.62(\mathrm{~m}, 1 \mathrm{H}), 3.57-3.53(\mathrm{~m}, 2 \mathrm{H}), 3.47(\mathrm{~s}, 4 \mathrm{H}), 3.38(\mathrm{~s}, 3 \mathrm{H}), 2.84-2.76(\mathrm{~m}, 1 \mathrm{H}), 2.19$ $1.91(\mathrm{~m}, 8 \mathrm{H}), 1.84(\mathrm{dd}, J=14.4,7.6 \mathrm{~Hz}, 1 \mathrm{H}), 1.69-1.40(\mathrm{~m}, 5 \mathrm{H}), 1.14(\mathrm{~d}, J=6.8,3 \mathrm{H}), 1.11(\mathrm{~s}, 21 \mathrm{H}), 1.05(\mathrm{~s}, 9 \mathrm{H})$, $0.97(\mathrm{~d}, J=6.4 \mathrm{~Hz}, 3 \mathrm{H}), 0.95(\mathrm{~s}, 3 \mathrm{H}), 0.91(\mathrm{~s}, 3 \mathrm{H}), 0.20(\mathrm{~s}, 9 \mathrm{H})$ 


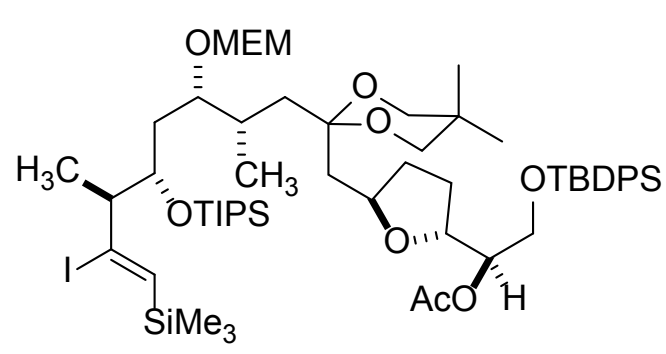

26

\section{[Scheme 6]}

${ }^{13} \mathrm{C}$ NMR $\left(100 \mathrm{MHz}, \mathrm{CDCl}_{3}\right) \delta 170.6,137.4,135.6,135.5,133.2,129.6,127.64$, 127.61, 125.1, 99.7, 95.2, 80.4, 76.2, 76.1, 75.7, 72.0, 71.8, 70.0, 67.5, 63.3, 59.0, $57.0,39.8,36.2,34.1,33.5,31.2,29.5,28.4,26.7,22.9,22.7,21.1,19.2,18.39$, $18.36,16.6,14.6,13.0,-1.1$

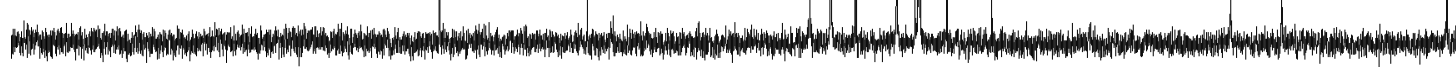

200

180

160

140

120

100

80

60

40

20

ppm 


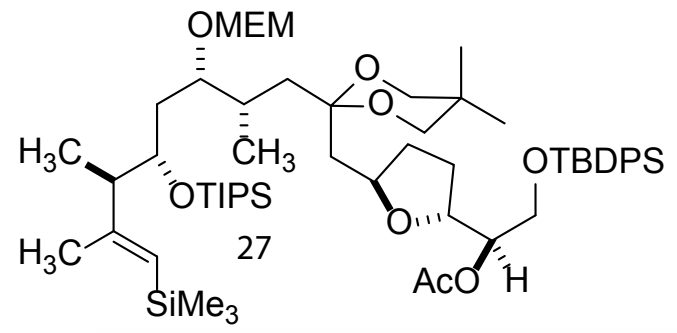

[Scheme 6]

${ }^{1} \mathrm{H}$ NMR $\left(400 \mathrm{MHz}, \mathrm{CDCl}_{3}\right) \delta 7.69-7.62(\mathrm{~m}, 4 \mathrm{H}), 7.43-7.34(\mathrm{~m}, 6 \mathrm{H}), 5.29(\mathrm{~s}, 1 \mathrm{H}), 4.95(\mathrm{dd}, J=10.6,5.0 \mathrm{~Hz}, 1 \mathrm{H})$ 4.71 (s, 2H), 4.22 (app. q, $J=6.4 \mathrm{~Hz}, 1 \mathrm{H}), 4.15-4.01(\mathrm{~m}, 2 \mathrm{H}), 3.79$ (app. d, $J=5.2 \mathrm{~Hz}, 2 \mathrm{H}), 3.76-3.69(\mathrm{~m}, 1 \mathrm{H})$, $3.68-3.58(\mathrm{~m}, 2 \mathrm{H}), 3.54-3.50(\mathrm{~m}, 2 \mathrm{H}), 3.45(\mathrm{~s}, 4 \mathrm{H}), 3.36(\mathrm{~s}, 3 \mathrm{H}), 2.44-2.36(\mathrm{~m}, 1 \mathrm{H}), 2.17-1.95(\mathrm{~m}, 7 \mathrm{H}), 1.91(\mathrm{dd}, J$ $=14.6,2.6 \mathrm{~Hz}, 1 \mathrm{H}), 1.85-1.78(\mathrm{~m}, 4 \mathrm{H}), 1.68-1.39(\mathrm{~m}, 5 \mathrm{H}), 1.09-1.03(\mathrm{~m}, 33 \mathrm{H}), 0.96-0.92(\mathrm{~m}, 6 \mathrm{H}), 0.90(\mathrm{~s}, 3 \mathrm{H})$, $0.09(\mathrm{~s}, 9 \mathrm{H})$ 


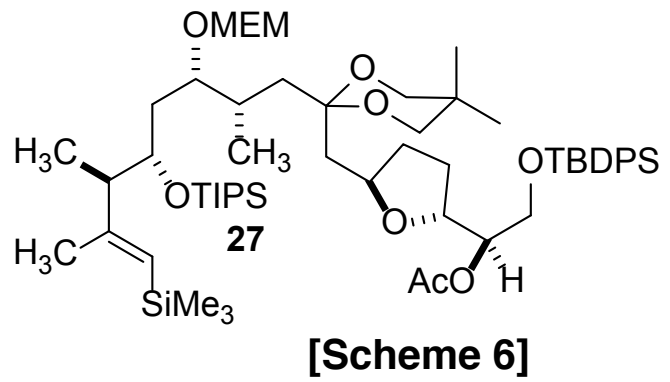

${ }^{13} \mathrm{C} \mathrm{NMR}\left(100 \mathrm{MHz}, \mathrm{CDCl}_{3}\right) \delta 170.6,156.5,135.6,135.5,133.4,133.3,129.7,127.7,127.6$ 124.2, 99.8, 95.1, 80.3, 76.2, 76.1, 75.7, 72.0, 71.8, 70.0, 69.9, 67.4, 63.3, 59.0, 49.7, 39.8,

$36.5,34.6,33.5,31.0,29.6,28.4,26.7,22.9,22.8,21.5,21.2,19.2,18.4,16.4,13.5,13.0,0.09$ 


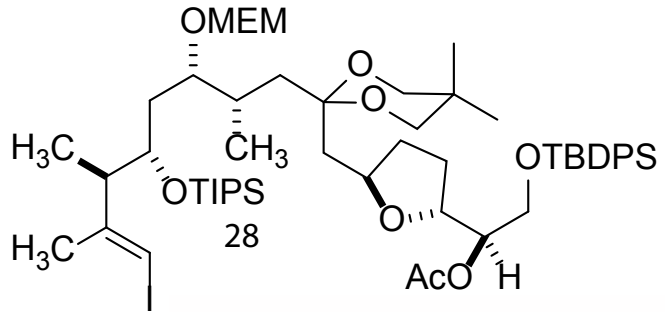

[Scheme 6]

${ }^{1} \mathrm{H} \mathrm{NMR}\left(400 \mathrm{MHz}, \mathrm{CDCl}_{3}\right) \delta 7.66(\mathrm{t}, J=6.2 \mathrm{~Hz}, 4 \mathrm{H}), 7.44-7.33(\mathrm{~m}, 6 \mathrm{H}), 6.05(\mathrm{~s}, 1 \mathrm{H}), 4.97(\mathrm{dd}, J=10.6,5.0 \mathrm{~Hz}$, $1 \mathrm{H}), 4.73(\mathrm{~d}, J=6.6 \mathrm{~Hz}, 1 \mathrm{H}), 4.69(\mathrm{~d}, J=6.6 \mathrm{~Hz}, 1 \mathrm{H}), 4.23(\mathrm{dd}, J=13.0,7.0 \mathrm{~Hz}, 1 \mathrm{H}), 4.12-4.03(\mathrm{~m}, 1 \mathrm{H}), 4.02-$ $3.97(\mathrm{~m}, 1 \mathrm{H}), 3.81$ (app. d, $J=4.8 \mathrm{~Hz}, 2 \mathrm{H}), 3.74-3.63(\mathrm{~m}, 2 \mathrm{H}), 3.63-3.57(\mathrm{~m}, 1 \mathrm{H}), 3.56-3.52(\mathrm{~m}, 2 \mathrm{H}), 3.49(\mathrm{~d}, 11.2$ $\mathrm{Hz}, 2 \mathrm{H}), 3.42(\mathrm{~d}, J=11.2 \mathrm{~Hz}, 2 \mathrm{H}), 3.38(\mathrm{~s}, 3 \mathrm{H}), 2.67-2.58(\mathrm{~m}, 1 \mathrm{H}), 2.16-1.78(\mathrm{~m}, 14 \mathrm{H}), 1.70-1.57(\mathrm{~m}, 1 \mathrm{H}), 1.57-$ $1.52(\mathrm{~m}, 2 \mathrm{H}), 1.43(\mathrm{dd}, J=14.0,6.8 \mathrm{~Hz}, 1 \mathrm{H}), 1.12(\mathrm{~d}, J=6.4 \mathrm{~Hz}, 3 \mathrm{H}), 1.08(\mathrm{~s}, 21 \mathrm{H}), 1.04(\mathrm{~s}, 9 \mathrm{H}), 0.98(\mathrm{~s}, 3 \mathrm{H}), 0.95$ $(\mathrm{d}, J=6.4 \mathrm{~Hz}, 3 \mathrm{H}), 0.87(\mathrm{~s}, 3 \mathrm{H})$

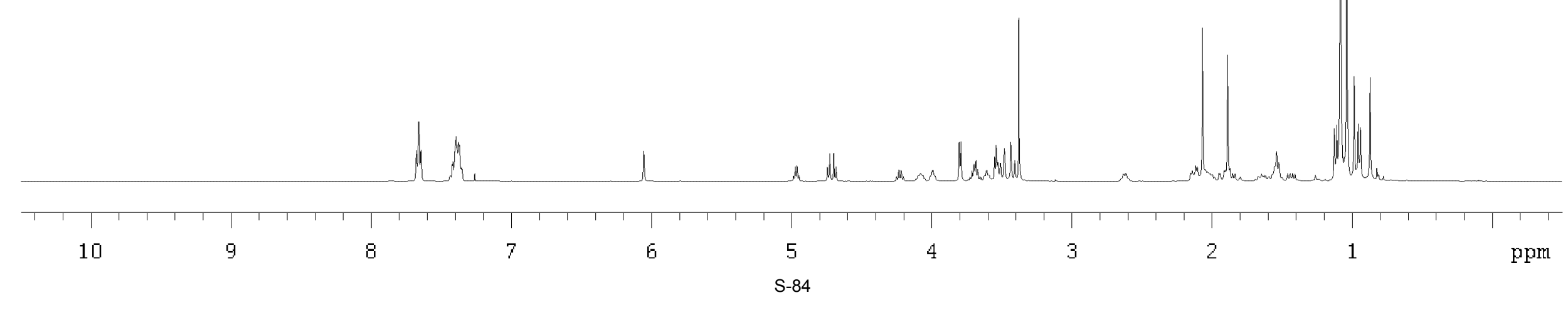




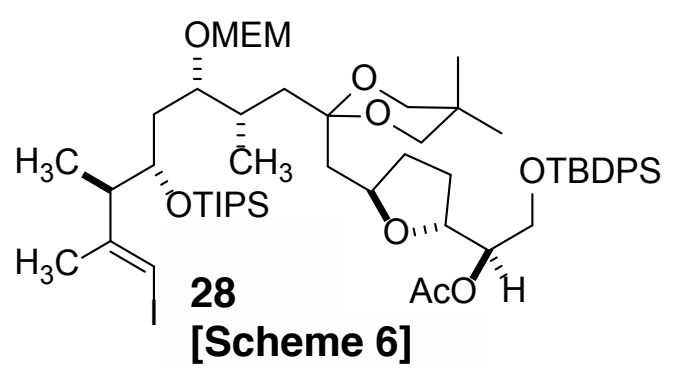

${ }^{13} \mathrm{C}$ NMR $\left(100 \mathrm{MHz}, \mathrm{CDCl}_{3}\right) \delta 170.5,149.4,135.54,135.46,133.3,133.2,129.6,127.63,127.60$, $99.8,94.9,79.8,77.6,76.2,76.0,75.6,72.6,71.8,70.0,69.9,67.4,63.2,59.0,47.9,39.0,37.3$, 23.0, 22.7, 21.1, 19.1, 18.3, 16.4, 14.7, 12.9;

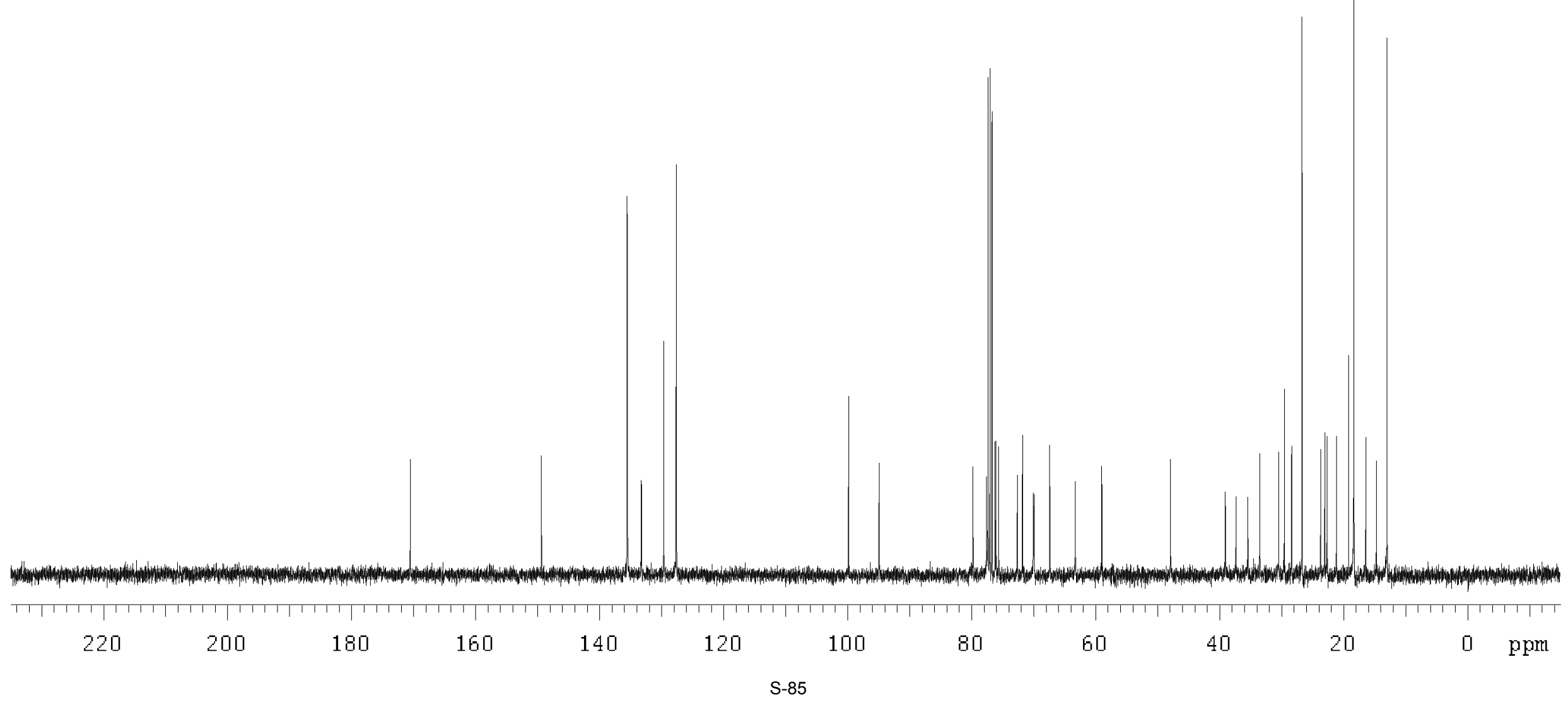

